[American Journal of Science, Vol. 314, January, 2014, P. 187-234, DOI 10.2475/01.2014.06]

\title{
A MESOZOIC ANDEAN-TYPE OROGENIC CYGLE IN SOUTHEASTERN CHINA AS RECORDED BY GRANITOID EVOLUTION
}

\author{
KONG-YANG ZHU****, ${ }^{*}$ ZHENG-XIANG LI* ${ }^{*}$, XI-SHENG XU**, \\ and SIMON A. WILDE*
}

\begin{abstract}
Petrology, magnetic susceptibilities, zircon U-Pb ages, zircon $\mathrm{Hf}$ isotopes and whole-rock geochemical data are used to constrain the evolution of Mesozoic high-potassium granitic rocks that record an Andean-type orogenic cycle in the southeastern China segment of the Western Pacific. Decreasing melting pressures of the granitic magmas from the Late Triassic to the Early Cretaceous, as reflected by decreasing $\mathrm{Sm} / \mathrm{Yb}$ ratios, point to a general trend of crustal attenuation with time in western Zhejiang Province. Five distinct stages of granitic magmatism are identified: (1) 230 to 215 Ma: high-temperature, high-pressure dehydration melting in a reduced and thickened crust caused by flat-slab subduction of the paleo-Pacific Plate; (2) 170 to 150 Ma: low-temperature, high-pressure water-fluxed melting in an oxidized and thickened crust caused by the foundering of the paleo-Pacific Plate; (3) 140 to 130 Ma: low-temperature, low-pressure dehydration melting of the continental crust caused by extension of the lithosphere; (4) 130 to 125 Ma: high-temperature, low-pressure dehydration melting of the refractory materials in the continental crust caused by further extension of the lithosphere and possibly basaltic underplating; and (5) 115 to 100 Ma: emplacement of fractionation products of hydrous basalts from the enriched continental lithospheric mantle.
\end{abstract}

Key words: high-potassium granitic rocks, Andean-type orogenic cycle, southeastern China, Western Pacific, Mesozoic

\section{INTRODUCTION}

Granitic magmas are generally considered to be formed in the continental crust through partial melting and/or fractional crystallization (Klein and Philpotts, 2013). Theoretically, there are infinite types of granitic rocks because of complex sourcetemperature-pressure- $\mathrm{H}_{2} \mathrm{O}$-redox conditions and differentiation processes in the crust. Despite this, it has been recognized that igneous rocks produced at a given time in a specific region commonly exhibit certain similarities in terms of their mineral and geochemical characteristics (Bowen, 1928). The purpose of this study is therefore to identify such common characteristics among Mesozoic granitoids in eastern South China and to understand why such common characteristics vary with time. Such knowledge can provide important constraints on the tectonic history of the Western Pacific.

However, it remains a challenge to link the various petrological and geochemical properties of granitic rocks to the processes (and sources) that produced them. One popular approach is that first proposed by Chappell and White (1974), which emphasizes the sources of granitic rocks as a key factor controlling their characteristics. This approach originally classified granites into two types: I-type (from igneous source rocks) and S-type (from sedimentary source rocks). Such a classification is intrinsically independent of tectonic processes. This scheme has been further developed into the I-S-A-M-H classification scheme where "A" means anorogenic (Loiselle and Wones, 1979), "M" represents "mantle-derived," and "H" stands for "hybrid" types (Castro and

* ARC Centre of Excellence for Core to Crust Fluid Systems (CCFS) and The Institute for Geoscience Research (TIGeR), Department of Applied Geology, Curtin University, GPO Box U1987, Perth, WA 6845, Australia

** School of Earth Sciences and Engineering, Nanjing University, Nanjing, 210093, China

† Corresponding authors: Email: Kongyang.Zhu@student.curtin.edu.au; Telephone: +61-8-92663710) and Email: Z.li@curtin.edu.au; Telephone: +61-8-92662453. 
others, 1991). Although this classification scheme is useful, the different types may overlap. For instance, a S-type granite can also be an A-type granite, and highly felsic I-type granites generally have an A-type affinity. Another approach is to analyze tectonic environments using trace element discrimination diagrams, such as those proposed by Pearce and others (1984). Although many of these diagrams have gained immense popularity, as Pearce and others (1984) maintain in their original paper, "the fields on the discriminant diagrams strictly reflect source regions (and crystallization histories) rather than tectonic regimes." Therefore, the direct use of such diagrams for tectonic environment analysis requires caution. Yet a third approach focuses on physico-chemical conditions, such as the role and sources of water, and temperature and pressure, in granite petrogenesis (Whitney, 1988; Miller and others, 2003; Bachmann and Bergantz, 2008), which is the main approach adopted in this paper.

South China is characterized by widespread Mesozoic granitic rocks (fig. 1A). There is a consensus that the paleo-Pacific Plate subducted under the South China Block (SCB) during the Mesozoic and that subduction was at least partly responsible for the granitic magmatism (Jahn and others, 1990; Zhou and Li, 2000). Nevertheless, the question remains as to when subduction started. The answer varies from Permian ( $\mathrm{Li}$ and Li, 2007), Jurassic (Zhou and others, 2006), to Cretaceous (Chen and others, 2008). In addition, the geometry and mechanics of the subduction zone are also in debate. A key to resolve these issues is to understand the petrogenesis of the widespread Mesozoic magmatic rocks in the region, and particularly that of the Jurassic-Early Cretaceous "arc-like" high-K calc-alkaline granitoids. Current models include formation in continental magmatic arcs (Charvet and others, 1994; Lapierre and others, 1997; Zhou and Li, 2000) or partial melting of the continental lithosphere metasomatized by previous subduction, similar to the Oligocene calc-alkaline rocks of the North American Cordillera (Davis and Hawkesworth, 1993). In this study, we systematically sampled and analyzed a series of high-K granitic and coeval/cogenetic mafic-intermediate rocks in western Zhejiang Province within a region of $16000 \mathrm{~km}^{2}$, covering an age range from the Triassic to Cretaceous (fig. 1C). Magnetic properties, petrography, whole-rock geochemistry, zircon $\mathrm{U}-\mathrm{Pb}$ ages and zircon $\mathrm{Hf}$ isotopes of these samples were investigated to constrain how the source-temperature-pressure-waterredox conditions in the continental lithosphere changed at different stages of the Mesozoic evolution of this area, thus enabling us to test the various models.

\section{GEOLOGICAL SETTING AND PETROLOGY}

\section{Geological Setting}

The South China Block is composed of the Yangtze Block in the northwest and the Cathaysia Block in the southeast (fig. 1B). The Jiang-Shao Fault Zone (fig. 1C) is generally regarded as the boundary between the two blocks in Zhejiang Province (Zhang and others, 2005) and it separates our study area into two parts. In the southeast part of the study region, the oldest rocks of the Cathaysia Block are Paleoproterozoic granitoids and metamorphic rocks (fig. 1C) (Yu and others, 2009; Yu and others, 2012; Xia and others, 2012). In the northwest part, the Phanerozoic strata are underlain by Neoproterozoic rocks associated with the amalgamation and later rifting between the Yangtze and Cathaysia blocks ( $\mathrm{Li}$ and others, 2002; Ye and others, 2007; Li and others, 2008; Li and others, 2009). During the Early Paleozoic (>460-420 $\mathrm{Ma})$, South China underwent an intraplate orogenic event ( $\mathrm{Li}$ and others, 2010). From the Permian to the Cretaceous, another widespread "intracontinental" orogeny (the Indosinian Orogeny) occurred in the South China Block, accompanied with extensive deformation (fig. 1B) and some granitic magmatism. The Permo-Triassic folds and thrusts generally have a NE-SW trend and migrated from the coast to the continental interior ( $\mathrm{Li}$ and $\mathrm{Li}, 2007)$. In the study region, the orogeny deformed Carboniferous to 


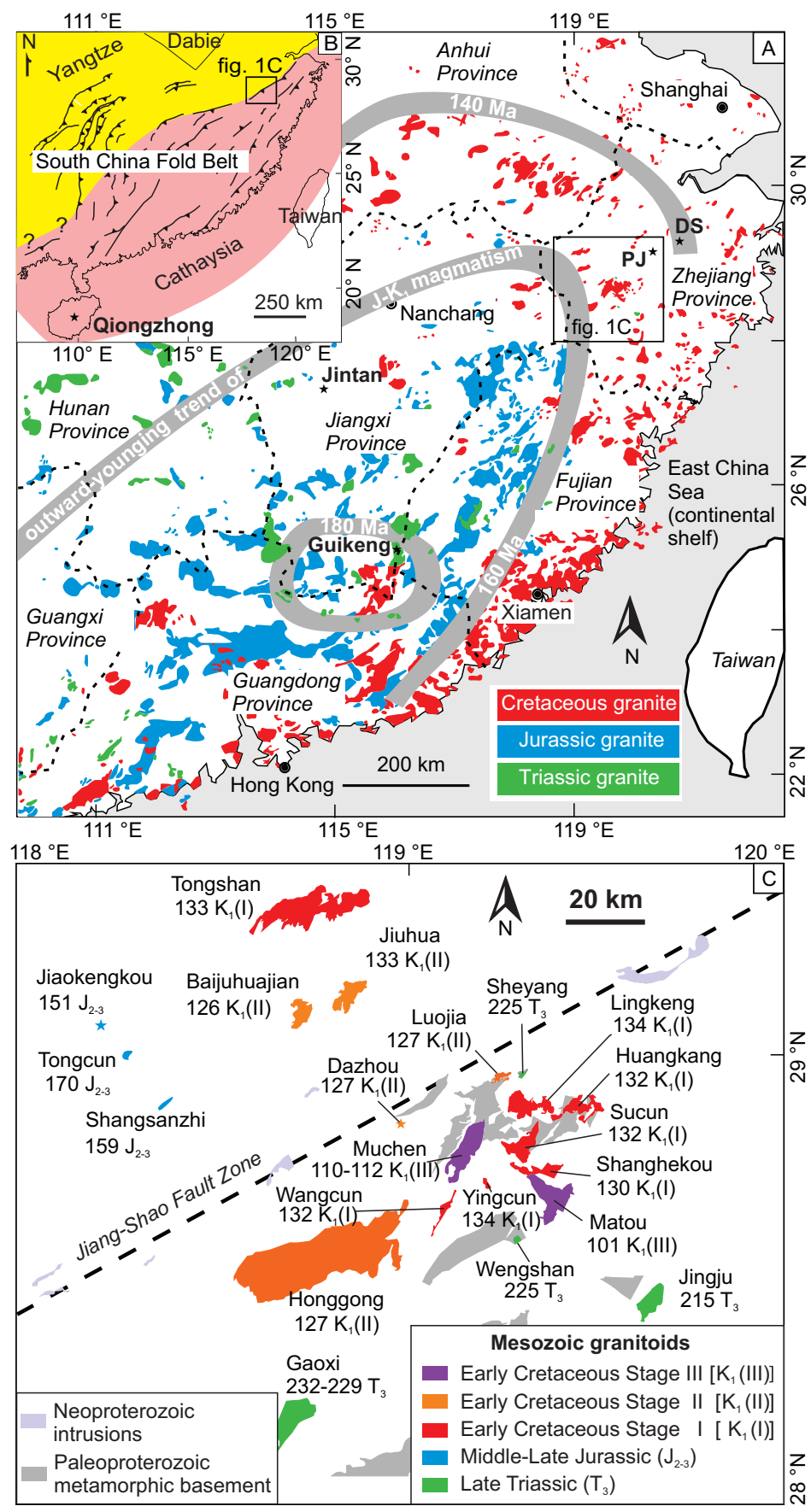

Fig. 1. (A) Distribution of Mesozoic granitic rocks in the South China Block, modified after Zhou and others (2006). The oceanward-younging trend of the Jurassic and Cretaceous magmatism is from Li and others (2013b). PJ: Pujiang basalt; DS: Dashuang quartz monzonite. (B) Major Mesozoic thrust faults in South China. The two components of the South China Block are shown in different colors (after Li and others, 2010). (C) The granitic intrusions in this study and their ages (see table 1 for data sources). The Paleoproterozoic metamorphic basement and Neoproterozoic intrusions (our unpublished data) are also shown. The Jiang Zhao Fault Zone is the inferred boundary between the Yangtze and Cathasia blocks. 


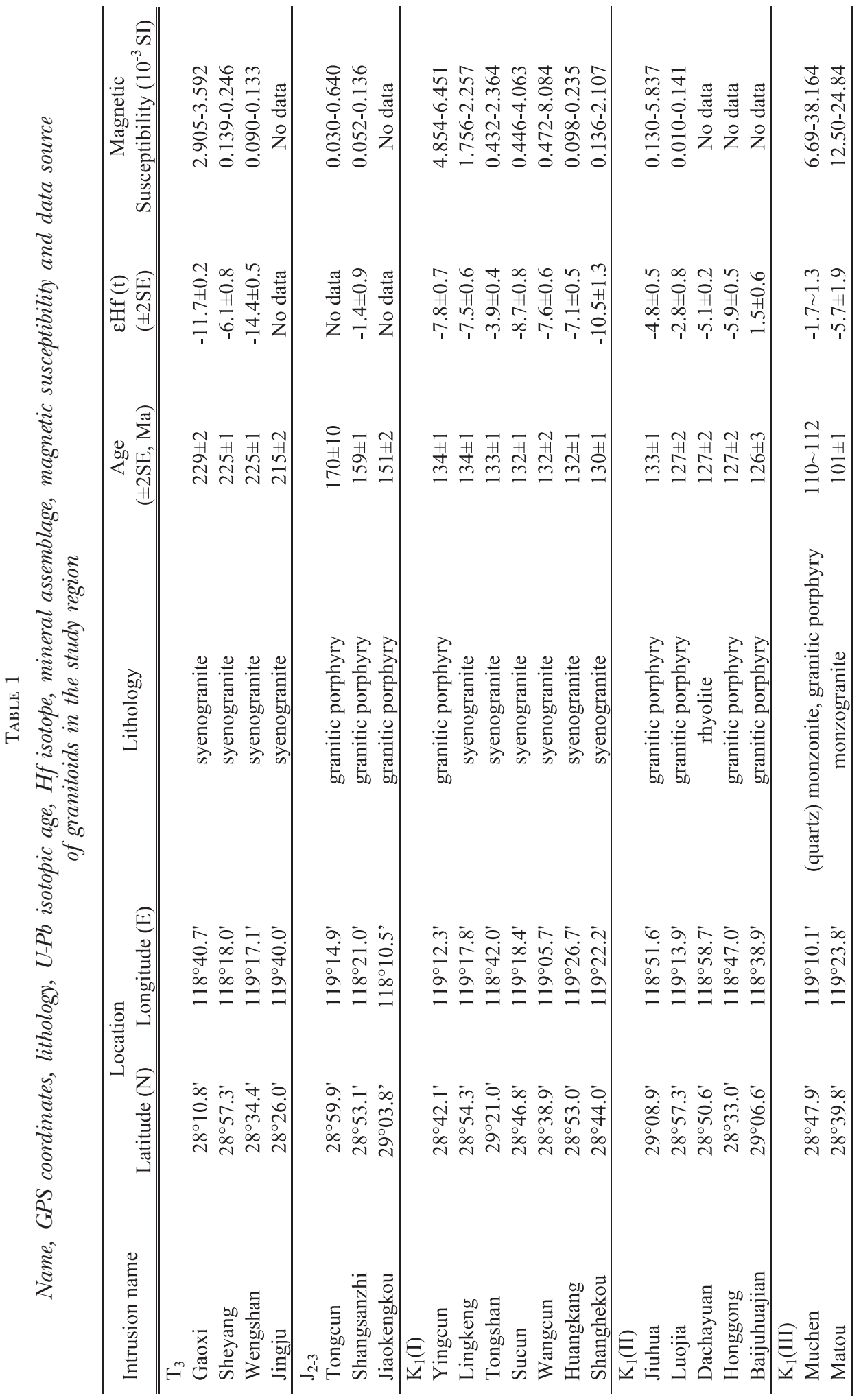




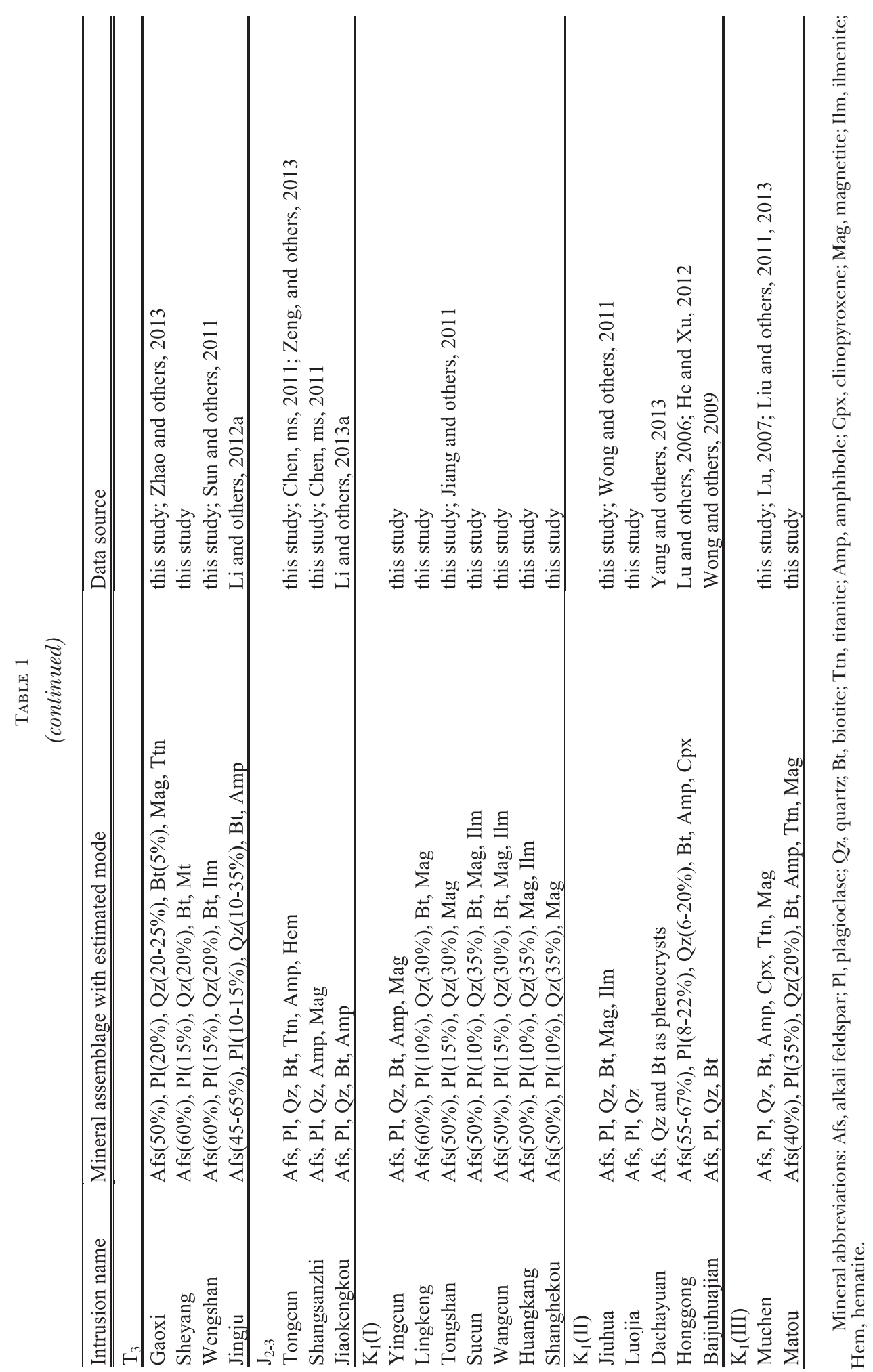


mid-Triassic platform carbonate strata, whereas post-orogenic Jurassic-Cretaceous volcanic and clastic strata unconformably overlie older rocks (ZGS, 1965; FGS, 1972; Charvet and others, 1994, p. 389).

\section{Sampling and Petrography}

Representative granitic samples were collected from 16 granitic intrusions in the study region (fig. 1C). We list in table 1 the positions, mineral compositions and other information on these intrusions; some of them have been previously studied. The nomenclature in this study follows the IUGS QAP classification (Le Maitre, 2002). Typical photographs of the outcrops, hand specimens and thin sections are shown in fig. 2. The magnetic susceptibility was measured on fresh and flat surfaces in the field, or on hand samples in the laboratory, using a Terraplus KT-10 magnetic susceptibility meter with 5-6 analyses carried out for each sample (table 1).

Triassic intrusions, as demonstrated by precise zircon U-Pb ages reported later, include the Gaoxi, Sheyang, Wengshan and Jingju syenogranites (fig. 1C). They intruded the Paleoproterozoic Badu Complex in western Zhejiang Province (Sheyang, Wengshan and Jingju plutons) and Early Paleozoic metamorphic rocks in northern Fujian Province (Gaoxi plutons). The Early Cretaceous strata either overlie, or are in fault contact with, these Triassic intrusions (ZGS, 1966; Sun and others, 2011; Li and others, 2012a; Zhao and others, 2013). All the Triassic granites are coarse-grained syenogranites and contain pink microcline megacrysts 1 to $2 \mathrm{~cm}$ in size (figs. 2A-2D). The mineral composition is quartz, feldspar and biotite, with accessory zircon, titanite, apatite, magnetite and ilmenite. In addition, the Jingju syenogranite also contains amphibole. All these Triassic rocks underwent deformation, to different extents, as reflected by the undulose extinction and recrystallization of quartz (fig. 2B). The magmatic susceptibilities of the Triassic samples are $0.11-3.59 \times 10^{-3}$ SI.

Jurassic samples were collected from the Tongcun and Shangsanzhi granitic porphyries (figs. 1C and 2E-2H) that intruded folded Lower Paleozoic strata. The rocks are porphyritic and the phenocrysts consist of quartz, alkali feldspar, plagioclase (An $\sim 30$ for the Tongcun porphyry), biotite and calcic clinoamphibole. Sericitization is common in feldspars. Ferromagnesian minerals in the Shangsanzhi porphyry are strongly altered, and the chlorite-calcite assemblage is likely derived from altered calcic clinoamphibole. The percentages of phenocrysts in the Tongcun and Shangsanzhi porphyries are $\sim 47$ percent and $\sim 36$ percent, respectively. The accessory minerals are zircon, apatite, and Fe-Ti oxides. The Tongcun porphyry also contains titanite, and has associated Mo $(\mathrm{Cu})$ mineralization dated at $163.9 \pm 1.9 \mathrm{Ma}$ (Re-Os isochron age) (Chen, ms, 2011; Qiu and others, 2013; Zeng and others, 2013). The rocks have low magnetic susceptibilities $\left(0.030-0.640 \times 10^{-3} \mathrm{SI}\right)$.

Early Cretaceous intrusions are the largest and most widespread granitic rocks in the study region, with the Honggong quartz syenitic porphyry and the Muchen Complex reaching tens of kilometers in length. Based on their textures and analytical results, the Early Cretaceous intrusions can be further divided into three stages.

The first stage of the Early Cretaceous granitic rocks (figs. 1C and 2I-2P) includes the Sucun syenogranite, Yingcun porphyry, Lingkeng syenogranite, Wangcun syenogranite, Huangkang syenogranite and Shanghekou syenogranite in the Cathaysia Block, and the Tongshan syenogranite in the Yangtze Block (fig. 1C). These rocks intruded the Paleoproterozoic Badu Complex and Early Cretaceous Moshishan Group in the Cathaysia Block and Paleozoic strata in the Yangtze Block. The rocks are highly evolved syenogranitic rocks with high modal alkali feldspar and quartz. The plagioclase generally has a low An mol percent ( $\sim 10 \%$, ZGS, 1966). The rocks contain biotite \pm calcic clinoamphibole, and have accessory zircon, apatite, Fe-Ti oxides, muscovite and allanite. The magnetic susceptibilities are low to moderate $\left(0.098-8.084 \times 10^{-3} \mathrm{SI}\right)$. 


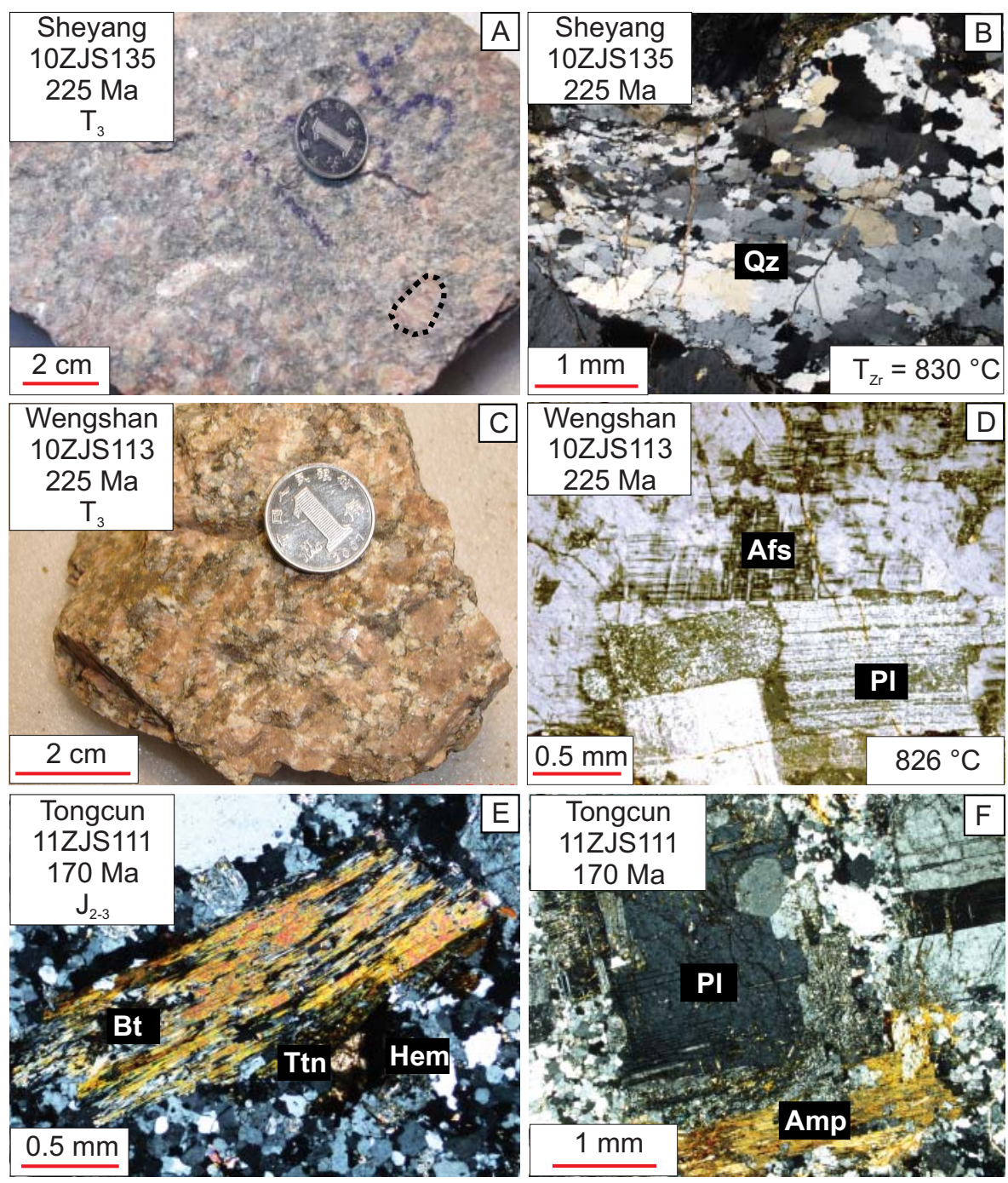

Fig. 2. Field, hand specimen and thin section photographs of the Mesozoic granitic rocks from western Zhejiang Province. All thin section photographs were taken under cross-polarized light. The temperatures shown are zircon saturation temperatures. (A, B): Sheyang syenogranite. The dark-colored minerals are mainly deformed biotite (Bt). A pink alkali feldspar megacryst (microline) is outlined with dotted line, showing deformation in thin section. Quartz grains (Qz) also show strong deformation, with undulose extinction and recrystallization. (C, D): Wengshan syenogranite. The petrographic characteristics are similar to the Sheyang syenogranite. Pink alkali feldspar megacrysts and medium- to coarse-grained texture are common features for the Triassic granites in Zhejiang Province. (E, F) Tongcun porphyry. The phenocrysts are quartz, alkali feldspar, plagioclase (PI), calc clinoamphibole (Amp), biotite (Bt), titanite (Ttn), and hematite (Hem).

The second stage of the Early Cretaceous granitic rocks (figs. 1C and 2Q-2T) includes the Luojia porphyry and Honggong quartz syenitic porphyry in the Cathaysia Block (intruding the Paleoproterozoic Badu Complex and Early Cretaceous Moshishan Group) and the Baijuhuajian porphyry and Jiuhua porphyry in the Yangtze Block (intruding Neoproterozoic and Early Cretaceous strata). These rocks are predomi- 

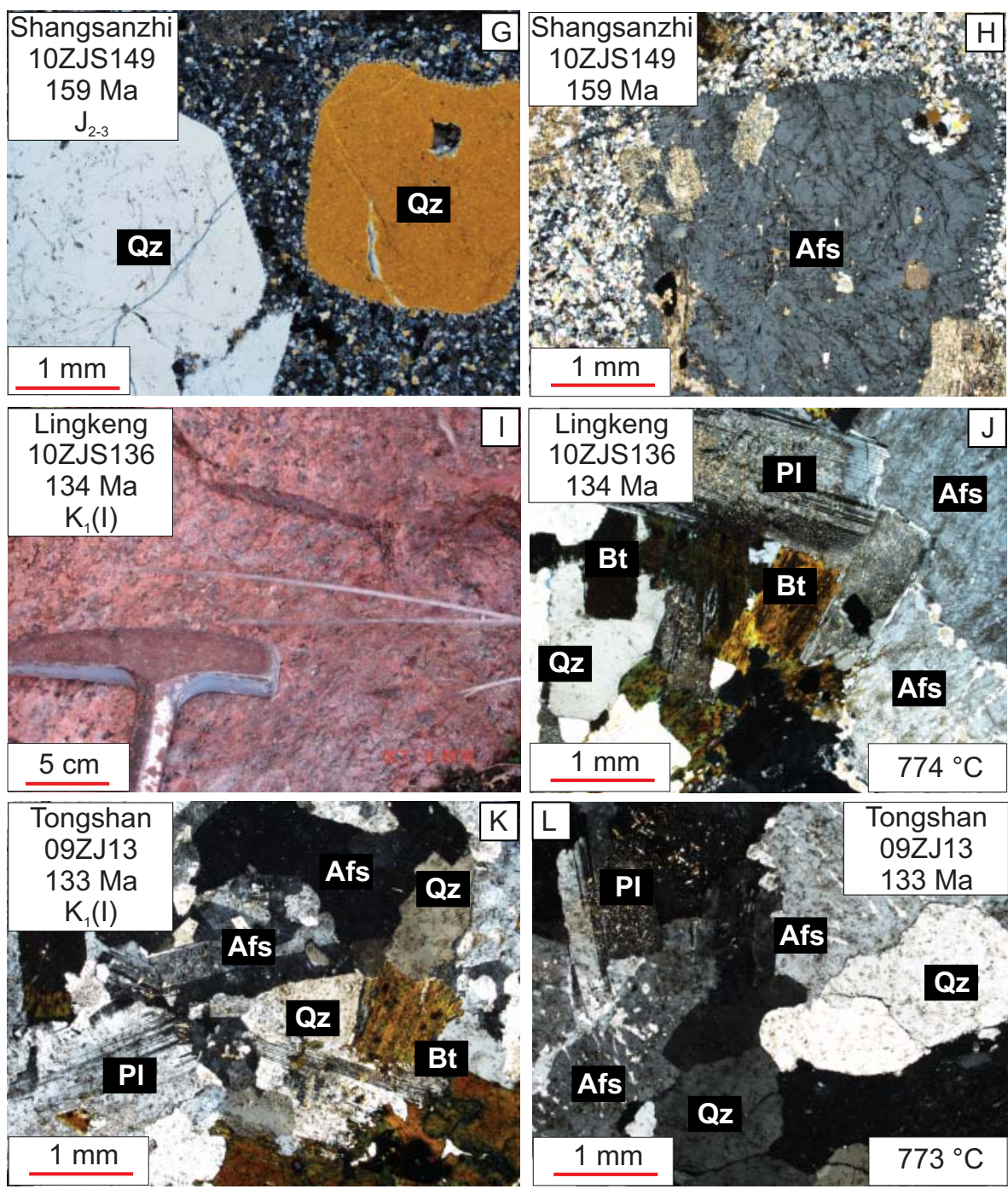

Fig. 2 (continued). (G, H) Shangsanzhi porphyry. Quartz (Qz) and alkali feldspar (Afs) phenocrysts occur in a fine-grained groundmass and are of similar size. (I, J) Lingkeng syenogranite with a mediumgrained texture. Some alkali feldspars show exsolution and quartz shows undulose extinction. (K, L) Tongshan syenogranite with a medium-grained texture. Some alkali feldspars show exsolution.

nantly porphyritic with alkali feldspar megacrysts. Quartz, alkali feldspar, plagioclase $\left(\mathrm{An}_{6-15}\right.$ for the Honggong quartz syenitic porphyry, JGS, 1980) and biotite are the major minerals, but the Honggong quartz syenitic porphyry also contains amphibole and clinopyroxene. The magnetic susceptibility intensities are low to moderate $(0.010$ $\left.5.837 \times 10^{-3} \mathrm{SI}\right)$.

The third stage of the Early Cretaceous granitic rocks is present only in the Cathaysia Block and includes the Muchen Complex and the Matou monzogranite (figs. 1C and 2U-2X), which intrude the Paleoproterozoic Badu Complex and the Early Cretaceous Moshishan Group. They are distinct from the other Mesozoic granites in 

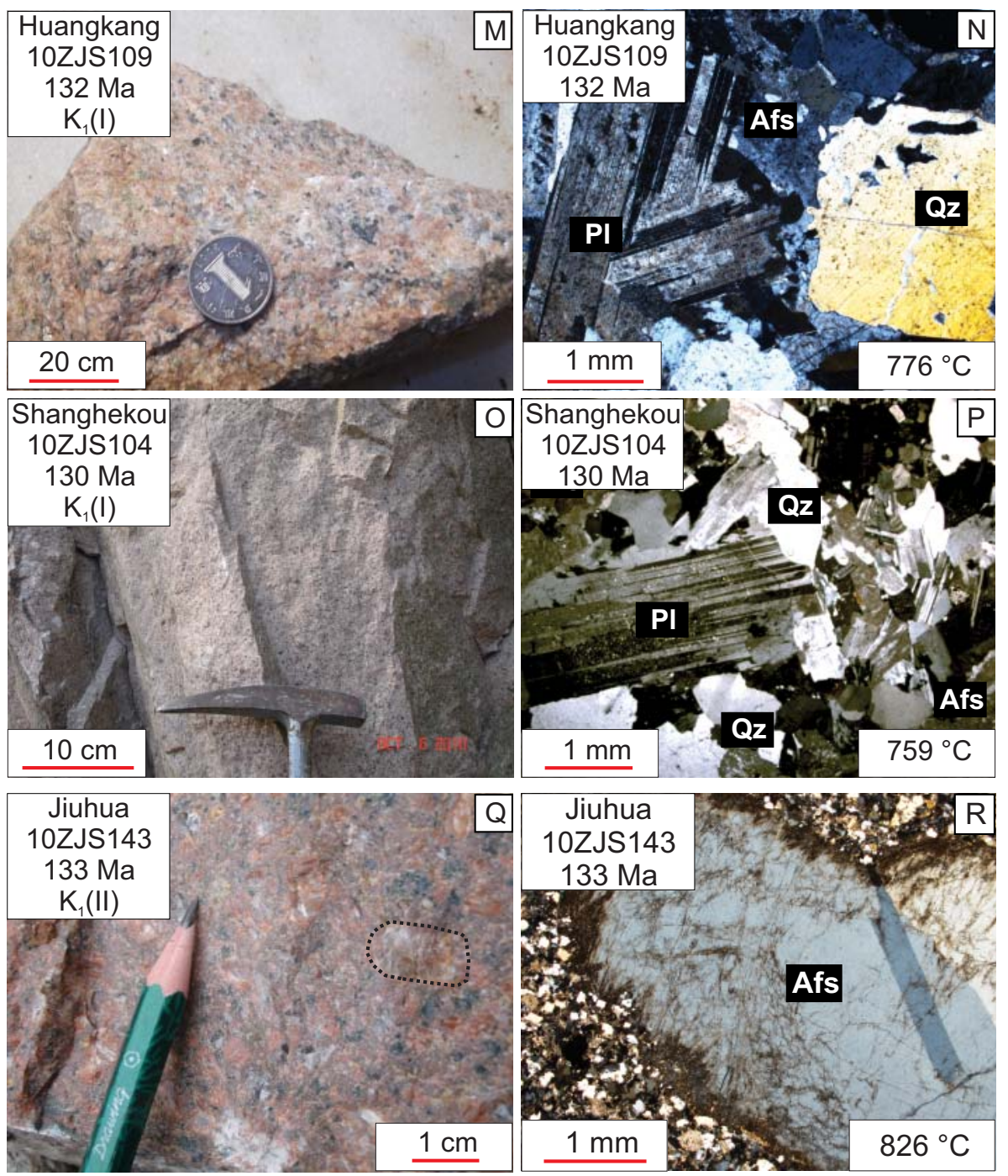

Fig. 2 (continued). (M-P) Huangkang and Shanghekou syenogranites, which are similar to the Lingkeng syenogranite. (Q-T) Jiuhua and Luojia (next page) granitic porphyries contain large alkali feldspar (Afs) crystals. An alkali feldspar megacryst is outlined with a dotted line in figure 2Q. Their porphyritic texture and lack of deformation distinguish them from the Triassic syenogranites.

terms of their significantly higher magnetic susceptibilities $\left(6.690-38.164 \times 10^{-3} \mathrm{SI}\right.$ for the Muchen Complex and 15.034-22.004 $\times 10^{-3}$ SI for the Matou monzogranite) and the occurrence of mafic microgranular enclaves (MME, figs. $2 \mathrm{U}$ and $2 \mathrm{~W}$ ). Mafic minerals include biotite, calcic clinoamphibole, titanite and magnetite. Accessory minerals include titanite, zircon and apatite. The Muchen Complex is highly variable, ranging from monzonite and quartz monzonite to porphyritic syenogranite, whereas the Matou pluton is a relatively homogeneous monzogranite. Plagioclase in these two intrusions has a much higher An mol percent (14-42\%, ZGS, 1966) than in the stage 1 and 2 granitic rocks. The MMEs in both intrusions are dioritic, and their size 

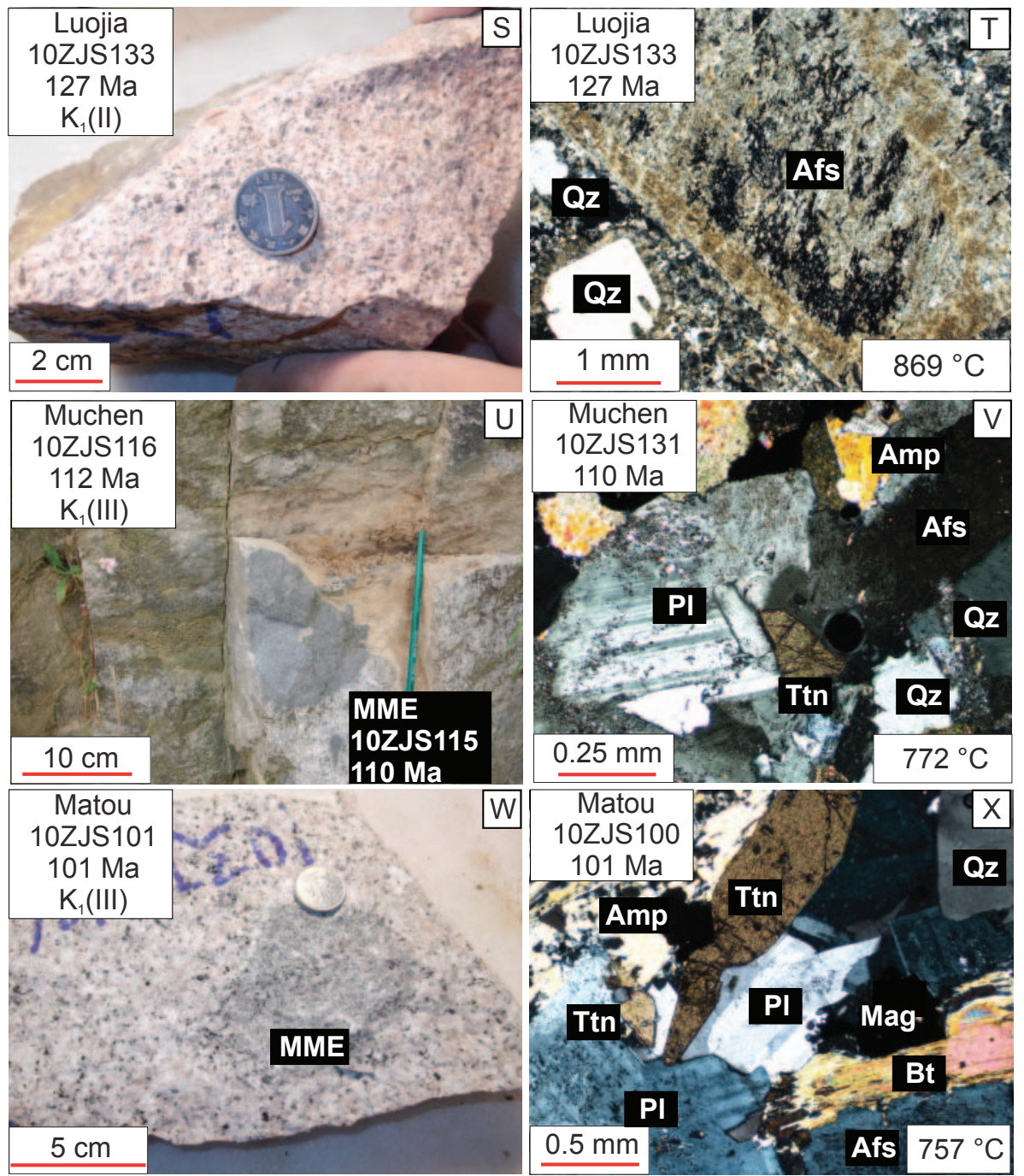

Fig. 2 (continued). (U-X) Muchen quartz monzogranite and Matou monzogranite, both of which contain titanite (Ttn), biotite (Bt), calcic clinoamphibole (Amp) and mafic enclaves (MME).

varies from sub-centimeter to approximately $30 \mathrm{~cm}$ in diameter. A MME sample (10ZJS115) was collected from the Muchen Complex for further study.

ANALYTICAL METHODS

Whole-rock Major and Trace Elements

Whole-rock powders for chemical analyses were prepared by crushing cleaned samples to 200-mesh using a ceramic ball mill. Major elements were analyzed using XRF. Glass beads were prepared from $1 \mathrm{~g}$ powders and $11 \mathrm{~g}$ lithum metaborate-lithium tetraborate mixtures. Major element analyses were then conducted on these fused glass beads using an ARL-9800 X-ray fluorescence spectrometer at the Centre of 
Modern Analysis, Nanjing University, with relative standard errors for $\mathrm{SiO}_{2}<\sim 1 \%$, $\mathrm{Al}_{2} \mathrm{O}_{3}<\sim 3 \%, \mathrm{CaO}, \mathrm{K}_{2} \mathrm{O}, \mathrm{Fe}_{2} \mathrm{O}_{3}, \mathrm{TiO}_{2}<\sim 5 \%$ and $\mathrm{MgO}, \mathrm{Na}_{2} \mathrm{O}, \mathrm{P}_{2} \mathrm{O}_{5}, \mathrm{MnO}<\sim 10 \%$.

Trace elements in the Tongshan granitic samples (09ZJ13, 09ZJ14, 09ZJ15) were analyzed, following $\mathrm{HF}+\mathrm{HNO}_{3}$ digestion, on a Finnigan MAT Element II ICP-MS at the State Key Laboratory of Mineral Deposits Research, Nanjing University. Digestion procedures were the same as those described in Gao and others (2003). Relative standard deviations (1SD) are less than 10 percent. Relative errors are less than 10 percent, based on measurements of USGS, GSJ and IGGE standards.

Trace elements in all other samples were analyzed, after $\mathrm{HF}+\mathrm{HNO}_{3}$ digestions in Teflon bombs, on an Agilent 7500a ICP-MS at the State Key Laboratory of Geological Processes and Mineral Resources, China University of Geosciences, Wuhan. Detailed procedures are similar to those described in Liu and others (2008).

\section{LA-ICPMS Zircon U-Pb Dating}

Zircons were extracted from separate portions of the original samples by heavyliquid and magnetic techniques and then hand-picked under a binocular microscope. They were mounted in epoxy resin and polished to about half their thickness. Cathodoluminescence (CL) images were taken using a Phillips XL-30 SEM at Curtin University.

LA-ICPMS zircon U-Pb dating was conducted on 16 samples from 15 intrusions (2 samples from the Matou monzogranite) using an Agilent 7500 ICP-MS equipped with a New Wave Research $213 \mathrm{~nm}$ laser at the State Key Laboratory of Mineral Deposits Research, Nanjing University. Analyses were conducted with a beam diameter of $32 \mu \mathrm{m}, 5 \mathrm{~Hz}$ repetition rate and energy of $10-20 \mathrm{~J} / \mathrm{cm}^{2}$. It took 120 seconds to acquire data for each analysis (40s on background and 80s on signal). Raw count rates for ${ }^{206} \mathrm{~Pb},{ }^{207} \mathrm{~Pb},{ }^{208} \mathrm{~Pb},{ }^{232} \mathrm{Th},{ }^{238} \mathrm{U}$ were collected for age determination. An homogeneous standard zircon, GEMOC/GJ-1 with a TIMS ${ }^{207} \mathrm{~Pb} /{ }^{206} \mathrm{~Pb}$ age of $608.5 \pm 0.4 \mathrm{Ma}$ (Jackson and others, 2004), was used to calibrate mass discrimination and isotope fractionation. Mud Tank zircon with a TIMS ${ }^{207} \mathrm{~Pb} /{ }^{206} \mathrm{~Pb}$ age of $732 \pm 5 \mathrm{Ma}$ (Black and Gulson, 1978) was used to monitor the reproductivity and stability of the instrument. Each run included 15-18 analyses which contained 10-12 unknowns, 1-2 Mud Tank zircons, and beginning and ending with two GJ-1 analyses. Raw mass spectrometric data reduction was carried out using the GLITTER 4.4 program. Because ${ }^{204} \mathrm{~Pb}$ cannot be measured, the common lead correction was carried out using the Excel program ComPbCorr\#3_15G (Andersen, 2002). The concentration of $\mathrm{U}$ and Th in zircons was calculated using a linear relationship of the element concentrations against backgroundcorrected signal count rates, comparing with GJ-1 standard zircon (Th $=8 \mathrm{ppm}, \mathrm{U}=$ 330 ppm, Wang and others, 2010).

\section{SHRIMP Zircon U-Pb Dating}

The Tongshan syenogranite (sample 09ZJ14) and the Wangcun syenogranite (sample 10ZJS121) were dated using the SHRIMP zircon U-Pb method. The zircons were mounted in epoxy resin with zircon standards M257 and Temora 2. Mounts were abraded and polished to reveal the zircon centers. CL images were taken with a Phillips XL30 at Curtin University. The analyses were conducted using a Sensitive High Resolution Ion Microrobe (SHRIMP) at the John de Laeter Centre of Mass Spectrometry, Curtin University. Analytical conditions were: $10 \mathrm{kV}, 2-3 \mathrm{nA} \mathrm{O}$-primary beam, $30 \mu \mathrm{m}$ diameter spot, mass resolution $5200\left({ }^{254} \mathrm{UO}, 1 \%\right.$ peak height $)$. Standard zircon M257 was used to calibrate $\mathrm{U}, \mathrm{Th}$ and $\mathrm{Pb}$ isotopic ratios and $\mathrm{U}$, Th contents (Nasdala and others, 2008). Standard zircon Temora 2 (Black and others, 2004) was analysed to monitor reproducibility and instrument stability. The measured ${ }^{204} \mathrm{~Pb}$ was used for the common $\mathrm{Pb}$ correction assuming a Broken Hill $\mathrm{Pb}$ isotopic composition $\left({ }^{204} \mathrm{~Pb} /{ }^{206} \mathrm{~Pb}\right.$ 
$\left.=0.0625,{ }^{207} \mathrm{~Pb} /{ }^{206} \mathrm{~Pb}=0.9618,{ }^{208} \mathrm{~Pb} /{ }^{206} \mathrm{~Pb}=2.2285\right)$. The data reduction was carried out using the SQUID 2.5 (Lugwig, 2009) and Isoplot 3.71 (Lugwig, 2008) programs.

\section{MC-LA-ICPMS Zircon Lu-Hf Isotope Analysis}

In-situ zircon Hf isotopes for samples 10ZJS108 (Sucun syenogranite), 10ZJS109 (Huangkang syenogranite), 10ZJS121 (Wangcun syenogranite), 10ZJS129 (Yingcun porphyry), 10ZJS131 (quartz monzonite, Muchen Complex), 10ZJS132 (quartz monzonite, Muchen Complex), 10ZJS133 (Luojia porphyry), and 10ZJS136 (Lingkeng syenogranite) were analyzed with a Thermo-Scientific Neptune Plus MC-ICPMS equipped with a New Wave Research UP-193 FX laser ablation system at Nanjing University. The analyses were conducted on the same spots or CL domains where the $\mathrm{U}-\mathrm{Pb}$ isotopic analyses were obtained, with spots of 35 or $50 \mu \mathrm{m}$ diameter, $5-8 \mathrm{~Hz}$ repetition rate and energy of approximately $10-15 \mathrm{~J} / \mathrm{cm}^{2} .{ }^{172} \mathrm{Yb},{ }^{173} \mathrm{Yb},{ }^{175} \mathrm{Lu},{ }^{176} \mathrm{Hf}$ (with ${ }^{176} \mathrm{Yb}$ and ${ }^{176} \mathrm{Lu}$ interferences), ${ }^{177} \mathrm{Hf},{ }^{178} \mathrm{Hf},{ }^{179} \mathrm{Hf},{ }^{180} \mathrm{Hf}$ (with ${ }^{180} \mathrm{~W}$ interference) were collected. The isobaric interferences of ${ }^{176} \mathrm{Lu}$ and ${ }^{176} \mathrm{Yb}$ on ${ }^{176} \mathrm{Hf}$ were corrected by applying ${ }^{176} \mathrm{Yb} /{ }^{172} \mathrm{Yb}=0.5886$ and ${ }^{176} \mathrm{Lu} /{ }^{175} \mathrm{Lu}=0.02656$ (Chu and others, 2002). Mass bias was corrected by the exponential law (Russell and others, 1978): $R_{\text {true }}=R_{\text {measured }}\left(M_{2} / M_{1}\right)^{\mathrm{f}}$, where $R$ is the ratio of the ion beam at masses $M_{2}$ and $\mathrm{M}_{1}$ and $\mathrm{f}$ is the mass discrimination coefficient. The mass discrimination coefficient (f) of Hf was calculated from ${ }^{177} \mathrm{Hf}$ and ${ }^{179} \mathrm{Hf}$. The mass discrimination coefficients of $\mathrm{Yb}$ and $\mathrm{Lu}$ were calculated from ${ }^{172} \mathrm{Yb}$ and ${ }^{173} \mathrm{Yb}$, assuming $\mathrm{Yb}$ and $\mathrm{Lu}$ have a similar mass discrimination. The accepted ${ }^{172} \mathrm{Yb} /{ }^{173} \mathrm{Yb}$ ratio of 1.35274 and ${ }^{179} \mathrm{Hf}$ / ${ }^{177} \mathrm{Hf}$ ratio of 0.7325 ( $\mathrm{Chu}$ and others, 2002) were used as $\mathrm{R}_{\text {true }}$ in the calculations. Standard zircons 91500 and Mud Tank were also analyzed for monitoring the accuracy and precision of the instruments, with analytical ${ }^{176} \mathrm{Hf} /{ }^{177} \mathrm{Hf}$ ratios of $0.282320 \pm 14$ $(2 \mathrm{SE}, \mathrm{n}=47)$ and $0.282520 \pm 6(2 \mathrm{SE}, \mathrm{n}=66)$, respectively. These results are consistent with the solution data of Woodhead and Hergt (2005) and MC-ICP-MS results of Griffin and others (2006). Initial ${ }^{176} \mathrm{Hf} /{ }^{177} \mathrm{Hf}$ ratios were calculated using measured ${ }^{176} \mathrm{Lu} /{ }^{177} \mathrm{Hf}$ ratios and the ${ }^{176} \mathrm{Lu}$ decay constant of $1.867 \times 10^{-11} \mathrm{yr}^{-1}$ (Söderlund and others, 2004). The chondritic values of ${ }^{176} \mathrm{Lu} /{ }^{177} \mathrm{Hf}=0.0332$ and ${ }^{176} \mathrm{Hf} /{ }^{177} \mathrm{Hf}=0.282772$ (Blichert-Toft and Albarède, 1997) were utilized for $\varepsilon_{\mathrm{Hf}}$ calculation.

In-situ zircon Hf isotopes for samples 10ZJS101 (Matou monzogranite), 10ZJS104 (Shanghekou syenogranite), 10ZJS115 (mafic enclave from the Muchen Complex), 10ZJS116 (quartz monzonite from the Muchen Complex), 10ZJS125 (porphyritic syenogranite from the Muchen Complex), 10ZJS135 (Sheyang syenogranite), 10ZJS143 (Jiuhua porphyry) and 10ZJS149 (Shangsanzhi porphyry) were analyzed with a Nu Plasma multi-collector ICP-MS equipped with a New Wave Research $213 \mathrm{~nm}$ laser ablation system (He as carrier gas) at the Institute of Geochemistry, Chinese Academy of Sciences (Guiyang). The MC-ICPMS was first optimized with JMC-475 standard solution, using a Nu Instruments DSN-100 Desolvating Nebuliser System. The analyses were conducted on zircons with laser spots of $60 \mu \mathrm{m}$ diameter, repetition rate of $10 \mathrm{~Hz}$, ablation time of $60 \mathrm{~s}$, and laser energy of $0.155 \mathrm{~mJ} /$ pulse. The interferences of ${ }^{176} \mathrm{Lu}$ and ${ }^{176} \mathrm{Yb}$ on ${ }^{176} \mathrm{Hf}$ were corrected by applying ${ }^{176} \mathrm{Yb} /{ }^{173} \mathrm{Yb}=0.78696$ (Thirlwall and Anczkiewicz, 2004) and ${ }^{176} \mathrm{Lu} /{ }^{175} \mathrm{Lu}=0.02656$ (Chu and others, 2002). Mass bias was corrected by the exponential law. The mass discrimination coefficients of $\mathrm{Yb}(\mathrm{Lu})$ and Hf were calculated from ${ }^{173} \mathrm{Yb} /{ }^{171} \mathrm{Yb}$ and ${ }^{179} \mathrm{Hf} /{ }^{177} \mathrm{Hf}$. The ${ }^{173} \mathrm{Yb} /{ }^{171} \mathrm{Yb}$ and ${ }^{179} \mathrm{Hf}$ / ${ }^{177} \mathrm{Hf}$ ratios used in calculations were 1.12346 (Thirlwall and Anczkiewicz, 2004) and 0.7325 (Chu and others, 2002), respectively. Standard zircon 91500 was analyzed once every 10 unknowns to monitor the reproducibility and the stability of the instrument, and yielded a weighted average ratio of ${ }^{176} \mathrm{Hf} /{ }^{177} \mathrm{Hf}=0.282308 \pm 4(2 \mathrm{SE})$. 
RESULTS

\section{Zircon U-Pb Ages and Hf Isotopes}

The zircon LA-ICPMS and SHRIMP U-Pb data are presented in Appendix tables A1 (http:/ / earth.geology.yale.edu/ ajs/SupplementaryData/2014/02ZhuTableA.1.docx) and A2 (http://earth.geology.yale.edu/ ajs/SupplementaryData/2014/03ZhuTableA.2. docx) and the zircon Hf results are listed in Appendix table A3 (http://earth.geology. yale.edu/ ajs/SupplementaryData/2014/04ZhuTableA.3.docx). The results for individual samples, including representative CL images, are presented in figure 3. All the $\mathrm{U}-\mathrm{Pb}-\mathrm{Hf}$ results, together with some previously published data, are summarized in figure 4A. Most zircon grains have high $\mathrm{Th} / \mathrm{U}$ ratios and show well-developed oscillatory zoning in CL images, indicating their magmatic origin. Some zircons from the most siliceous granites, for example, the Shanghekou syenogranite (10ZJS104), have extremely high $\mathrm{U}$ and Th contents (up to $1-2$ wt.\%), which is probably related to low solubility of $\mathrm{U}$ in highly polymerized granitic melt (Farges and others, 1992), and the high whole-rock U/Zr ratios in these rocks. For instance, the whole-rock $\mathrm{U} / \mathrm{Zr}$ ratio of the Shangkekou syenogranite (10ZJS104) is 0.066; however, the ratios are only 0.018 to 0.020 for the Muchen monzogranite. The weighted mean ${ }^{206} \mathrm{~Pb} /{ }^{238} \mathrm{U}$ age of the dominant zircon population of each sample is interpreted to be the crystallization age of that sample. Except for inherited zircons, the values of $\varepsilon \mathrm{Hf}(\mathrm{t})$ were calculated using weighted mean ages from the zircon $\mathrm{U}-\mathrm{Pb}$ isotopic analyses for each sample. Uncertainties are quoted at $2 \mathrm{SE}$ (or 95\% confidence interval) for the weighted mean ages and $\varepsilon \mathrm{Hf}(\mathrm{t})$.

Matou monzogranite.-Zircon U-Pb isotopic analyses were carried out on two samples from the Matou monzogranite (10ZJS099 and 10ZJS101). Twenty-one analyses were conducted on twenty-one zircons from sample 10ZJS099 (fig. 3A). Th contents are 75 to $1194 \mathrm{ppm}$ and $\mathrm{U}$ contents are 66 to $741 \mathrm{ppm}$, with $\mathrm{Th} / \mathrm{U}=0.15-2.07$. Seventeen analyses are clustered on concordia and record a ${ }^{206} \mathrm{~Pb} /{ }^{238} \mathrm{U}$ weighted mean age of $101 \pm 1 \mathrm{Ma}(\mathrm{MSWD}=0.57)$. Spot 10ZJS099-14 is discordant and was therefore rejected from the calculation. Three inherited zircons are present. Spot 10ZJS099-9, with a ${ }^{207} \mathrm{~Pb} /{ }^{206} \mathrm{~Pb}$ age of $1741 \pm 23 \mathrm{Ma}$, implies the involvement of Paleoproterozoic basement materials. Spots 10ZJS099-6 and 10ZJS099-13, with ${ }^{206} \mathrm{~Pb} /{ }^{238} \mathrm{U}$ ages of $130 \pm 2 \mathrm{Ma}$ and $217 \pm 3 \mathrm{Ma}$, respectively, are also xenocrysts.

Twenty U-Pb analyses were conducted on twenty zircons from sample 10ZJS101 (fig. 3B). Th contents are 149 to $804 \mathrm{ppm}$ and $\mathrm{U}$ contents are 69 to $370 \mathrm{ppm}$, with $\mathrm{Th} / \mathrm{U}=1.14$ to 2.82 . Fifteen analyses yield a weighted mean ${ }^{206} \mathrm{~Pb} /{ }^{238} \mathrm{U}$ age of $101 \pm 1$ Ma (MSWD = 0.78). Spots 10ZJS101-12, 16, 17 are discordant and were rejected from the age calculation. Spots 10ZJS101-3 and 10ZJS101-10 have ages of $205 \pm 3 \mathrm{Ma}$ and $206 \pm 3 \mathrm{Ma}$, respectively, indicating incorporation of Triassic grains. Nineteen Hf isotopic analyses were obtained (fig. 3B). The two Triassic inherited zircons have $\varepsilon \mathrm{Hf}$ (t) values of -4.0 and -3.0 . For the zircons with a crystallization age of $101 \pm 1 \mathrm{Ma}$, there are two strongly negative values $(-15.8$ and -10.6$)$, whereas the remaining 15 zircons range between -1.8 and -6.2 .

Shanghekou syenogranite.-Twenty-one U-Pb analyses were conducted on twentyone zircons from the Shanghekou syenogranite (10ZJS104, fig. 3C). Th and U contents in most zircons show a range to high values (137-13904 ppm and 93-26112 ppm, respectively), with $\mathrm{Th} / \mathrm{U}=0.39-2.03$. Spots 10ZJS104-4a, 11a and 21a were rejected from the age calculation because of discordance. Spots 10ZJS104-7a and 18a, with concordant ${ }^{206} \mathrm{~Pb} /{ }^{238} \mathrm{U}$ ages of $148 \pm 2 \mathrm{Ma}$ and $151 \pm 2 \mathrm{Ma}$, respectively, are interpreted as inherited zircons. The remaining sixteen analyses cluster on concordia and yield a weighted mean ${ }^{206} \mathrm{~Pb} /{ }^{238} \mathrm{U}$ age of $130 \pm 1 \mathrm{Ma}(\mathrm{MSWD}=1.05)$. Seventeen $\mathrm{Hf}$ isotopic analyses were conducted on grains with concordant U-Pb ages. Fifteen concordant analyses have $\varepsilon \mathrm{Hf}(\mathrm{t})$ values ranging between -7.5 and -18.7 . The two inherited zircons have $\varepsilon \mathrm{Hf}(\mathrm{t})$ values of -10.0 and -9.8 . 

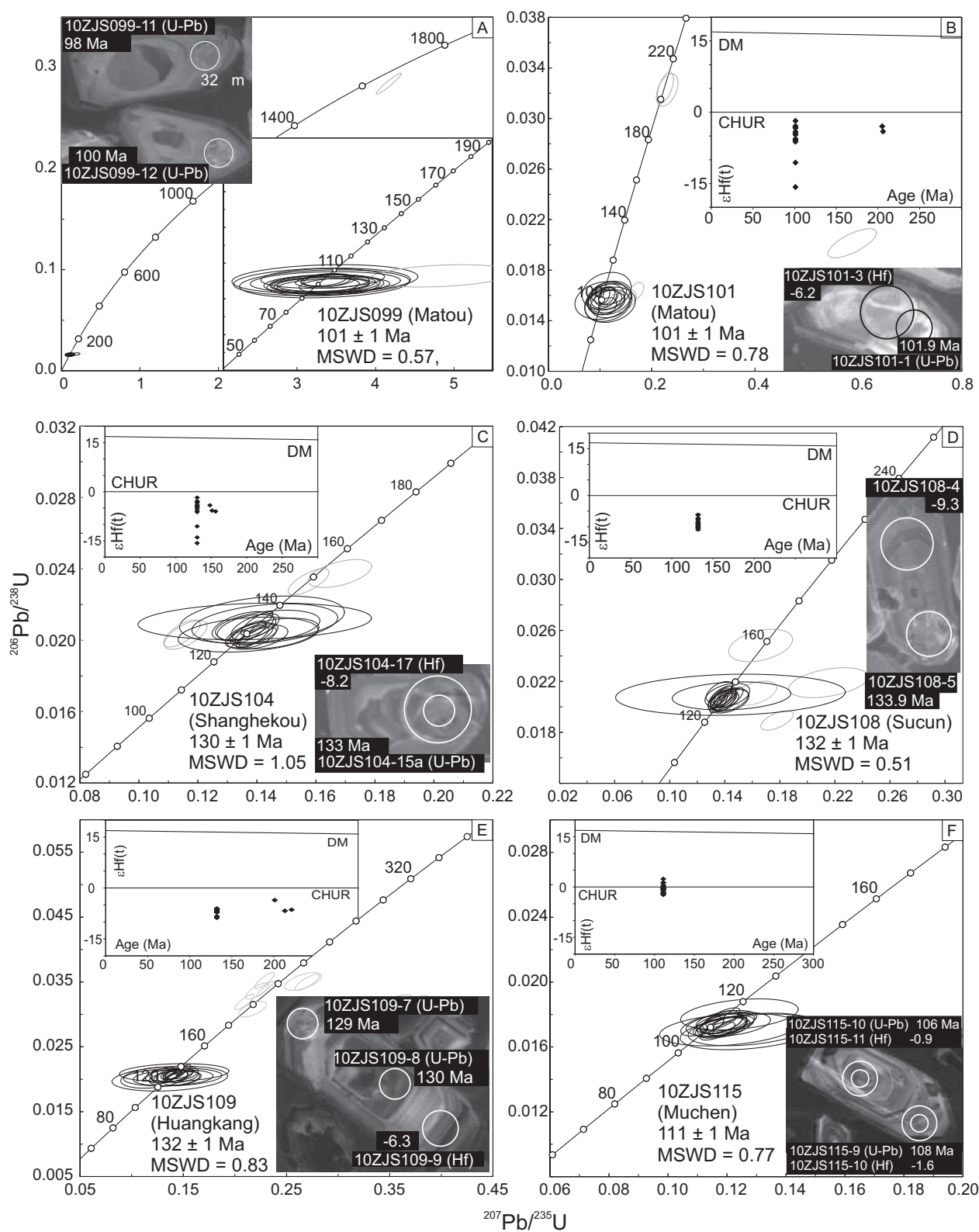

Fig. 3. Zircon CL images, zircon LA-ICPMS/SHIRMP U-Pb results and zircon MC-LA-ICPMS Hf isotopic results (where available) for eighteen Mesozoic granitic samples from western Zhejiang Province. In CL images, the oscillatory zoning of zircons shows their magmatic origin. Small circles (30 $\mu \mathrm{m}$ for SHRIMP and $32 \mu \mathrm{m}$ for LA-ICPMS ) indicate the analytical location for U-Pb isotopic analyses, with $2 \mathrm{SE}$. Larger circles $(35,50$ or $60 \mu \mathrm{m})$ in the CL images show the analytical positions of Hf isotope analyses, with $\varepsilon H f(t)$ values at $2 \mathrm{SE}$. On the concordia diagrams, the spots represented by gray error ellipses (2 SD) were excluded from the calculation of the mean age. (A-B): Matou monzogranite; (C) Shanghekou syenogranite; (D) Sucun syenogranite; (E) Huangkang synogranite; (F) MME within Muchen quartz monzonite (10ZJS116); 

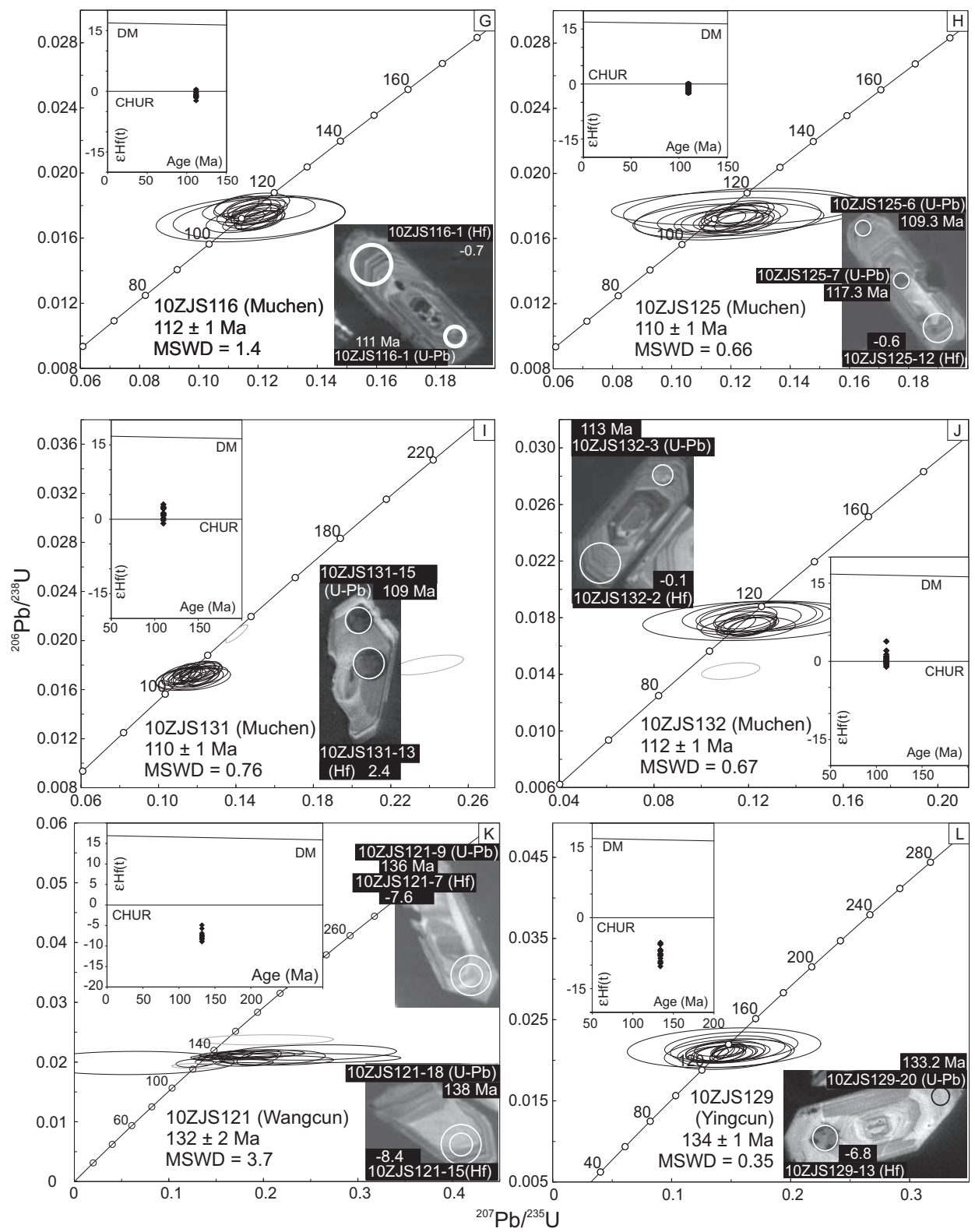

Fig. 3 (continued). (G) Muchen quartz monzonite; (H) Wangcun syenogranite (SHRIMP); (I) Muchen porphyry; (J) Yingcun porphyry; (K) Muchen quartz monzonite; (L) Muchen quartz monzonite;

Sucun syenogranite.-Twenty-three U-Pb analyses were conducted on 23 zircons from the Sucun syenogranite (10ZJS108, fig. 3D). The zircons have Th contents of 58 to $3096 \mathrm{ppm}$ and $\mathrm{U}$ contents of 41 to $4768 \mathrm{ppm}$, with $\mathrm{Th} / \mathrm{U}=0.65-2.27$. Spots 10ZJS108-03, 08, 09 are discordant and were rejected from the age calculation. Spots 10ZJS108-06 and 10ZJS108-04 are older than the rest and are inherited grains. The other 18 analyses cluster on concordia and yield a weighted mean ${ }^{206} \mathrm{~Pb} /{ }^{238} \mathrm{U}$ age of $132 \pm$ 

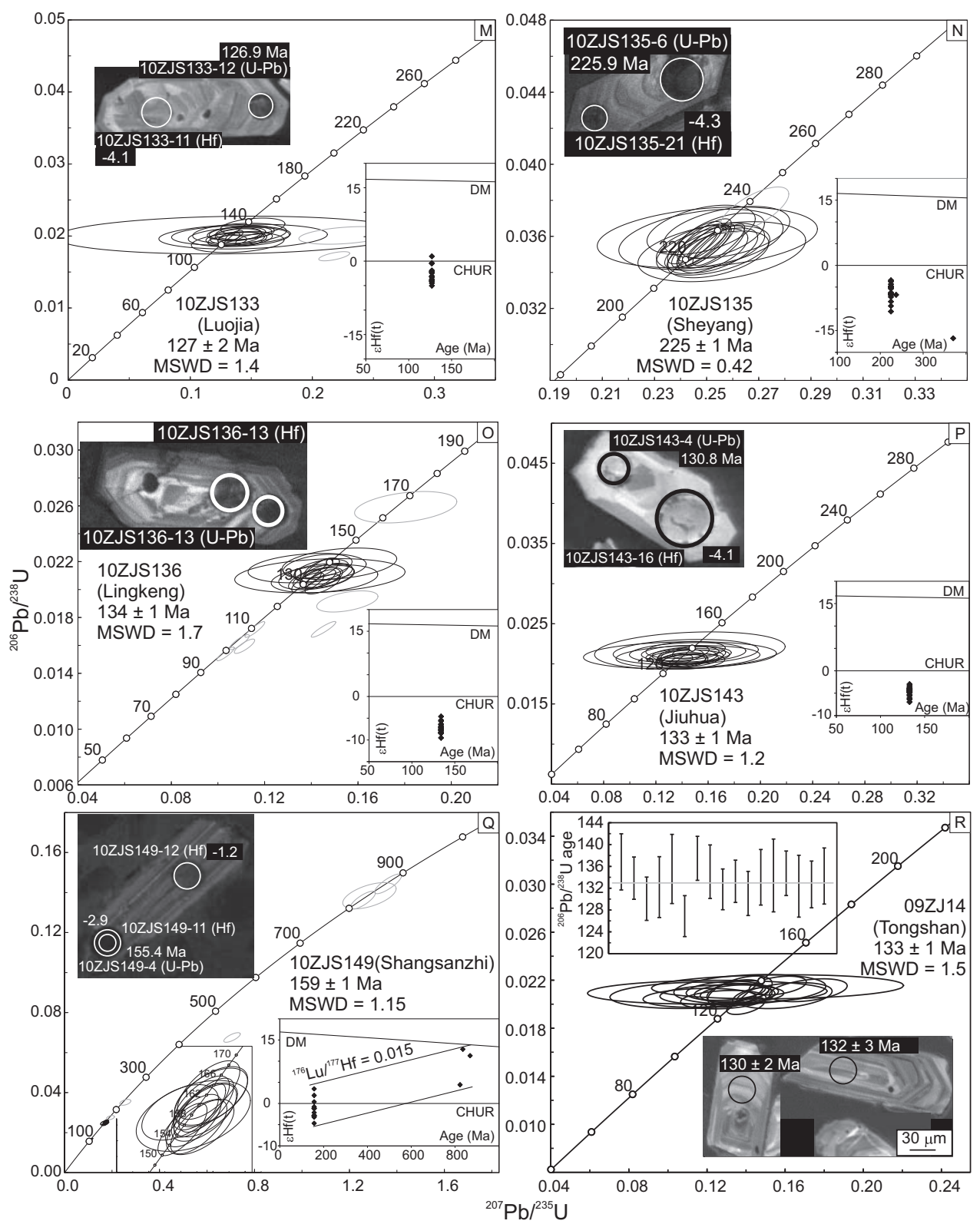

Fig. 3 (continued). (M) Luojia porphyry; (N) Sheyang syenogranite; (O) Lingkeng syenogranite; (P) Jiuhua porphyry; (Q) Shangsanzhi porphyry; (R) Tongshan syenogranite (SHRIMP).

$1 \mathrm{Ma}(\mathrm{MSWD}=0.51)$. Eleven Hf isotopic analyses were obtained from these grains and $\varepsilon \mathrm{Hf}(\mathrm{t})$ values range from -6.1 to -10.4 .

Huangkang syenogranite. - Thirty U-Pb analyses were conducted on twenty-nine zircons from the Huangkang syenogranite (10ZJS109, fig. 3E). Th and U contents are 51 to $5085 \mathrm{ppm}$ and 44 to $4963 \mathrm{ppm}$, respectively, with $\mathrm{Th} / \mathrm{U}=0.72-1.51$. There are two main age groups of zircon. The older group $(\mathrm{n}=10)$ have discordant ${ }^{206} \mathrm{~Pb} /{ }^{238} \mathrm{U}$ 

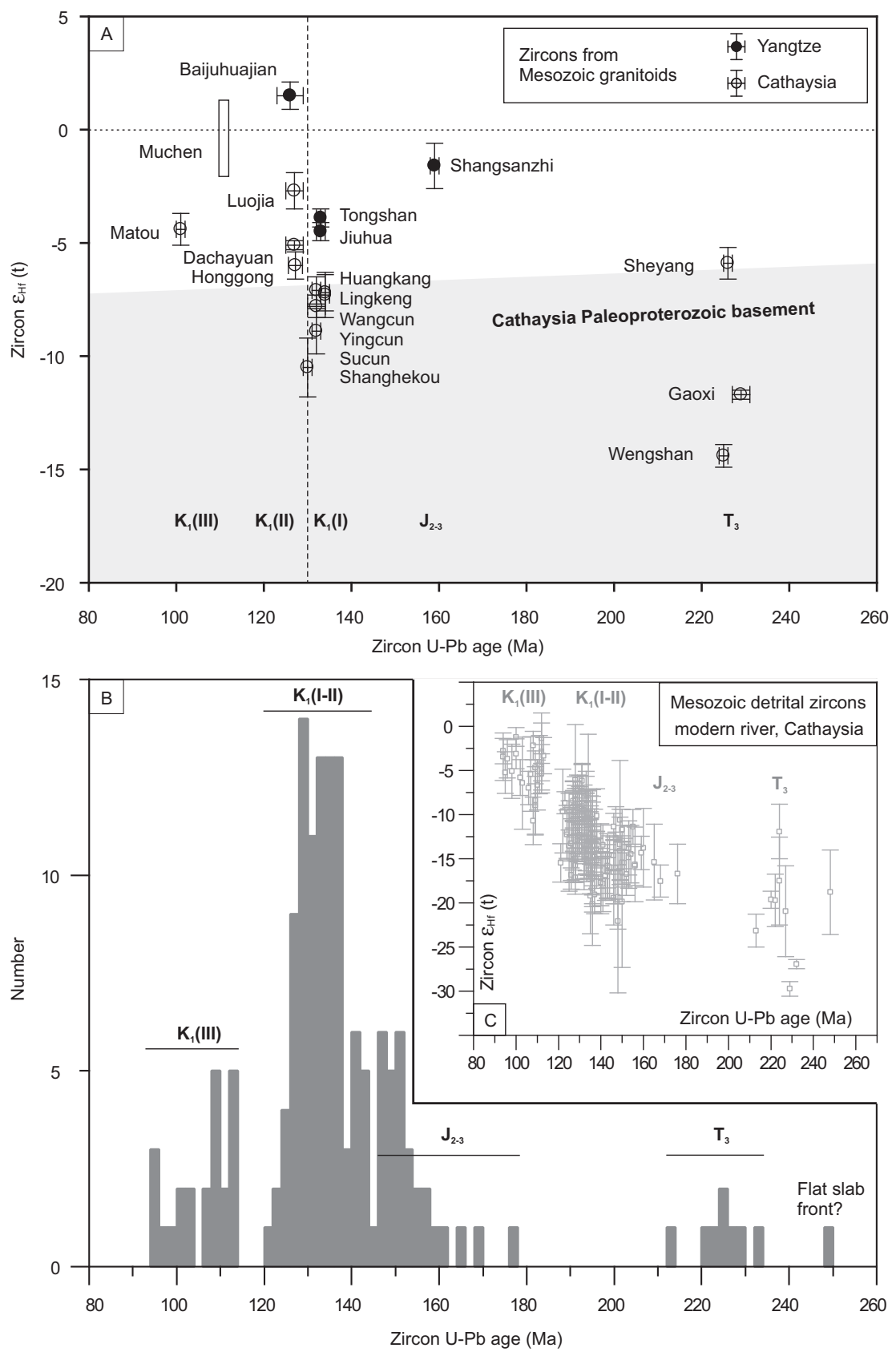

Fig. 4. (A) Zircon $\varepsilon H f(t)$ versus zircon $\mathrm{U}-\mathrm{Pb}$ ages for the Mesozoic granitic rocks in western Zhejiang Province, at 2 standard errors. The Hf isotopic compositions of the Paleoproterozoic crustal rocks of the Cathaysia Block are based on data from Yu and others (2009) and Xia and others (2012); the upper limit is constrained by data from Xiang and others $(2008)$, assuming ${ }^{176} \mathrm{Lu} /{ }^{177} \mathrm{Hf}=0.022$ for their amphibolite. The dash line at $130 \mathrm{Ma}$ is the best estimate of the boundary between the $\mathrm{K}_{1}(\mathrm{I})$ and $\mathrm{K}_{1}$ (II) granitic rocks; (B) Age spectrum of detrital zircons with Mesozoic ages in the study region (Cathaysia Block) (Xu and others, 2007); (C) Zircon $\varepsilon \mathrm{Hf}(\mathrm{t})$ versus zircon U-Pb ages for the same detrital zircons, $\varepsilon \mathrm{Hf}(\mathrm{t})$ values were recalculated with a decay constant of $1.867 \times 10^{-11} \mathrm{yr}^{-1}$ (Söderlund and others, 2004). 
ages of 223 to $196 \mathrm{Ma}$, and are inherited grains, whereas the younger concordant group $(\mathrm{n}=19)$ has a weighted mean ${ }^{206} \mathrm{~Pb} /{ }^{238} \mathrm{U}$ age of $132 \pm 1 \mathrm{Ma}(\mathrm{MSWD}=0.83)$. Spot 10ZJS109-19 records a ${ }^{206} \mathrm{~Pb} /{ }^{238} \mathrm{U}$ age of $166 \pm 2 \mathrm{Ma}$. Fifteen Hf isotopic analyses were obtained, with three zircons from the older group having $\varepsilon \mathrm{Hf}(\mathrm{t})$ values of -6.7 , -6.4 and -3.6 and twelve zircons from the younger group having $\varepsilon \mathrm{Hf}(\mathrm{t})$ values ranging between -8.8 and -6.1 .

Muchen Complex.-Zircons from five samples of the Muchen Complex were analyzed by LA-ICPMS and MC-ICPMS, including one enclave sample. In contrast to the other samples, zircon ages and $\varepsilon H f(t)$ values within individual samples show less of a spread. Our results are consistent with the zircon age and Hf isotopic results of Liu and others (2011) for an MME and a quartz monzonite sample.

Twenty U-Pb isotopic analyses were conducted on eighteen zircons from sample 10ZJS115, a mafic enclave (fig. 3F). Th and U contents are 178 to $1627 \mathrm{ppm}$ and 146 to $653 \mathrm{ppm}$, respectively, with $\mathrm{Th} / \mathrm{U}=1.02-2.54$. All analyses plot on concordia. The weighted mean ${ }^{206} \mathrm{~Pb} /{ }^{238} \mathrm{U}$ age is $111 \pm 1 \mathrm{Ma}(\mathrm{MSWD}=0.77)$. Twenty Hf isotopic analyses were conducted on sixteen zircons with U-Pb analyses (four zircons have two analyses) and $\varepsilon H f(t)$ values range from -2.3 to 2.4 .

Twenty U-Pb analyses were conducted on twenty zircons from sample 10ZJS116, a quartz monzonite (fig. 3G). Th and U contents are 164 to $906 \mathrm{ppm}$ and 107 to 589 $\mathrm{ppm}$, respectively, with $\mathrm{Th} / \mathrm{U}=1.28-2.22$. All analyses plot on or near concordia. The weighted mean ${ }^{206} \mathrm{~Pb} /{ }^{238} \mathrm{U}$ age of the 20 zircons is $112 \pm 1$ Ma $(\mathrm{MSWD}=1.4$ ). Eighteen $\mathrm{Hf}$ isotopic analyses were obtained and $\varepsilon \mathrm{Hf}(\mathrm{t})$ values range from -2.3 to 0.4 .

Seventeen U-Pb analyses were conducted on fifteen zircons from sample 10ZJS125, a porphyritic syenogranite (fig. $3 \mathrm{H})$, which is the most siliceous rock $\left(\mathrm{SiO}_{2}=72.18 \%\right.$ ) sampled from the Muchen Complex. Th and U contents are 95 to $478 \mathrm{ppm}$ and 66 to $566 \mathrm{ppm}$, respectively, with $\mathrm{Th} / \mathrm{U}=0.43-2.00$. All analyses plot on or near concordia. The weighted mean ${ }^{206} \mathrm{~Pb} /{ }^{238} \mathrm{U}$ age is $110 \pm 1 \mathrm{Ma}(\mathrm{MSWD}=0.66)$. Thirteen $\mathrm{Hf}$ isotopic analyses were conducted and $\varepsilon \mathrm{Hf}(\mathrm{t})$ values range from -2.6 to 0.2 .

Twenty-four U-Pb analyses were conducted on twenty-four zircons from sample 10ZJS131, a quartz monzonite (fig. 3I). Th and U contents are 151 to $4031 \mathrm{ppm}$ and 108 to $1065 \mathrm{ppm}$, respectively, with $\mathrm{Th} / \mathrm{U}=1.02-3.78$. Most analyses plot on or near concordia, although spot 10ZJS131-11 was rejected due to its strong discordance. One zircon (10ZJS131-6) has an older ${ }^{206} \mathrm{~Pb} /{ }^{238} \mathrm{U}$ age of $131 \pm 2 \mathrm{Ma}$. The other 22 analyses yield a weighted mean ${ }^{206} \mathrm{~Pb} /{ }^{238} \mathrm{U}$ age of $110 \pm 1 \mathrm{Ma}(\mathrm{MSWD}=0.76)$. Fifteen $\mathrm{Hf}$ isotopic analyses were obtained. $\varepsilon \mathrm{Hf}(\mathrm{t})$ values range from -0.9 to 3.0. The age of spot 10ZJS131-11 was assumed to be 110 Ma for the calculation.

Sixteen U-Pb analyses were conducted on fifteen zircons from sample 10ZJS132, a quartz monzonite (fig. 3J). Th and U contents are 70 to $522 \mathrm{ppm}$ and 90 to $413 \mathrm{ppm}$, respectively, with $\mathrm{Th} / \mathrm{U}=0.70-1.63$. Excluding one discordant analysis that has a younger age (Spot 10ZJS132-13), the weighted mean ${ }^{206} \mathrm{~Pb} /{ }^{238} \mathrm{U}$ age of the remaining fifteen analyses is $112 \pm 1 \mathrm{Ma}(\mathrm{MSWD}=0.67)$. Ten Hf isotopic analyses were conducted and $\varepsilon \mathrm{Hf}(\mathrm{t})$ values range from -1.0 to 3.8 .

Wangcun syenogranite.-Sample 10ZJS121 was analyzed using SHRIMP II. Twenty $\mathrm{U}-\mathrm{Pb}$ analyses were obtained from 20 zircons (fig. 3K) and Hf isotopic analyses were conducted on fifteen of them. Th and $\mathrm{U}$ contents are 105 to $938 \mathrm{ppm}$ and 113 to $872 \mathrm{ppm}$, respectively, with $\mathrm{Th} / \mathrm{U}=0.51-1.77$. Spot 10ZJS121-17 has a high content of common $\mathrm{Pb}(11 \%)$ and a strongly discordant age (not shown in the concordia diagram), and hence was rejected. Spot 10ZJS121-10 has a concordant ${ }^{206} \mathrm{~Pb} /{ }^{238} \mathrm{U}$ age of $151 \pm 2 \mathrm{Ma}$, indicating it is an inherited zircon. Spot 10ZJS121-8 was rejected because it has a younger ${ }^{206} \mathrm{~Pb} /{ }^{238} \mathrm{U}$ age $(124 \mathrm{Ma})$ than the main group, which was possibly caused by lead loss as indicated by cracks in the zircon. The remaining 
seventeen analyses cluster on concordia and yield a weighted mean ${ }^{206} \mathrm{~Pb} /{ }^{238} \mathrm{U}$ age of $132 \pm 2 \mathrm{Ma}(\mathrm{MSWD}=3.7)$. $\varepsilon \mathrm{Hf}(\mathrm{t})$ values range from -4.9 to -9.0 .

Yingcun porphyry.-Twenty $\mathrm{U}-\mathrm{Pb}$ and fourteen $\mathrm{Hf}$ analyses were conducted on 20 zircons from the Yingcun porphyry (10ZJS129, fig. 3L). Th and U contents are 172 to $1046 \mathrm{ppm}$ and 119 to $902 \mathrm{ppm}$, respectively, with $\mathrm{Th} / \mathrm{U}=1.08-1.96$. All analyses fall on or near concordia and record a weighted mean ${ }^{206} \mathrm{~Pb} /{ }^{238} \mathrm{U}$ age of $134 \pm 1 \mathrm{Ma}$ $(\mathrm{MSWD}=0.35)$. $\varepsilon \mathrm{Hf}(\mathrm{t})$ values range from -5.3 to -9.3 .

Luojia porphyry.-Twenty analyses were conducted on nineteen zircons from the Luojia porphyry (10ZJS133, fig. 3M). Th contents are 39 to $1124 \mathrm{ppm}$ and U contents are 24 to $682 \mathrm{ppm}$, with $\mathrm{Th} / \mathrm{U}=0.82-3.76$. Except for spots 10ZJS133-13 and 10ZJS133-20 that are strongly discordant, the remaining eighteen analyses yield a weighted mean ${ }^{206} \mathrm{~Pb} /{ }^{238} \mathrm{U}$ age of $127 \pm 2 \mathrm{Ma}(\mathrm{MSWD}=1.4)$. Thirteen Hf isotopic analyses were obtained and $\varepsilon \mathrm{Hf}(\mathrm{t})$ values range from -4.2 to 1.0.

Sheyang syenogranite. - Twenty-two U-Pb and twenty-one $\mathrm{Hf}$ analyses were carried out on 22 zircons from the Sheyang syenogranite (10ZJS135, fig. 3N). The zircons have Th contents of 72 to $1089 \mathrm{ppm}$ and $\mathrm{U}$ contents of 35 to $920 \mathrm{ppm}$, with $\mathrm{Th} / \mathrm{U}=$ 0.75-2.95. Spot 10ZJS135-19 with a discordant ${ }^{206} \mathrm{~Pb} /{ }^{238} \mathrm{U}$ age of $370 \pm 5 \mathrm{Ma}$ is an inherited grain. The ${ }^{206} \mathrm{~Pb} /{ }^{238} \mathrm{U}$ age of spot $10 \mathrm{ZJS} 135-21$ is $237 \pm 3$ : it is also interpreted as an inherited grain. The remaining 20 analyses cluster on concordia and yield a weighted mean ${ }^{206} \mathrm{~Pb} /{ }^{238} \mathrm{U}$ age of $225 \pm 1$ Ma with $\mathrm{MSWD}=0.42$. The $\varepsilon \mathrm{Hf}(\mathrm{t})$ values of the two inherited zircons (370 Ma and $237 \mathrm{Ma}$ ) are -16.8 and -6.8 , respectively; the $\varepsilon H f(t)$ values of the remaining zircons range from -3.4 to -10.6 .

Lingkeng syenogranite.-Twenty-four U-Pb analyses were conducted on twenty-three zircons from the Lingkeng syenogranite (10ZJS136, fig. 3O) and Hf analyses were conducted on eleven of them. Th and U contents are 133 to 10225 ppm and 79 to 8512 ppm, respectively. Spots 10ZJS136-04, 05, 06, 09, and 17, with ${ }^{206} \mathrm{~Pb} /{ }^{238} \mathrm{U}$ ages of ca. $100 \mathrm{Ma}$, are probably the result of $\mathrm{Pb}$ loss due to their high contents of $\mathrm{U}$ and $\mathrm{Th}$ and they are assumed to have the crystallization age of the Lingkeng syenogranite in the $\varepsilon H f(t)$ calculations. Spot 10ZJS136-20 has a discordant ${ }^{206} \mathrm{~Pb} /{ }^{238} \mathrm{U}$ age of $122 \pm 2 \mathrm{Ma}$. There is also a zircon with a concordant ${ }^{206} \mathrm{~Pb} /{ }^{238} \mathrm{U}$ age of $165 \mathrm{Ma}$, representing an inherited Jurassic zircon. The remaining seventeen analyses cluster on concordia and record a weighted mean ${ }^{206} \mathrm{~Pb} /{ }^{238} \mathrm{U}$ age of $134 \pm 1 \mathrm{Ma}(\mathrm{MSWD}=1.7)$. $\varepsilon \mathrm{Hf}(\mathrm{t})$ values range from -4.6 to -9.5 .

Jiuhua porphyry.-Twenty U-Pb analyses and seventeen $\mathrm{Hf}$ analyses were conducted on 20 zircons from the Jiuhua porphyry (10ZJS143, fig. 3P). Th and U contents are 47 to $366 \mathrm{ppm}$ and 32 to $176 \mathrm{ppm}$, respectively, with $\mathrm{Th} / \mathrm{U}$ ratios of 1.14-2.27. All spots are concordant and the weighted mean ${ }^{206} \mathrm{~Pb} /{ }^{238} \mathrm{U}$ age is $133 \pm 1 \mathrm{Ma}(\mathrm{MSWD}=1.2$ ). $\varepsilon H f(t)$ values range from -3.0 to -7.0 . The weighted average of $\varepsilon H f(t),-4.8 \pm 0.5$, is consistent with the analytical result $(-4.76 \pm 0.49)$ of Wong and others $(2011)$ on the same porphyry.

Shangsanzhi porphyry.-Twenty-one U-Pb analyses were conducted on 18 zircons from the Shangsanzhi porphyry (10ZJS149, fig. 3Q). Apart from spot 10ZJS149-20, the analyzed zircons have Th contents of 134 to $649 \mathrm{ppm}$ and $\mathrm{U}$ contents of 128 to 1180 ppm. In contrast, zircon 10ZJS149-20 has a very high U content (9925 ppm), a low $\mathrm{Th} / \mathrm{U}$ ratio of 0.03 and a concordant ${ }^{206} \mathrm{~Pb} /{ }^{238} \mathrm{U}$ age of $106 \mathrm{Ma}$, which is possibly related to Cretaceous hydrothermal processes. Spots 10ZJS149-02, 10ZJS149-03 and 10ZJS149-07 have concordant ${ }^{206} \mathrm{~Pb} /{ }^{238} \mathrm{U}$ ages of $823 \pm 10 \mathrm{Ma}, 836 \pm 15 \mathrm{Ma}$ and $869 \pm$ $11 \mathrm{Ma}$, respectively. Spots 10ZJS149-5, 10ZJS149-16 and 10ZJS149-18 have ${ }^{206} \mathrm{~Pb} /{ }^{238} \mathrm{U}$ ages of $223 \pm 4 \mathrm{Ma}, 422 \pm 6 \mathrm{Ma}$ and $175 \pm 3 \mathrm{Ma}$, respectively; all grains are interpreted as xenocrysts. The remaining fourteen analyses cluster on concordia and yield a weighted mean ${ }^{206} \mathrm{~Pb} /{ }^{238} \mathrm{U}$ age of $159 \pm 1 \mathrm{Ma}(\mathrm{MSWD}=1.15)$, which is consistent with 
the result $(155.6 \pm 2.5 \mathrm{Ma})$ of Chen $(2011)$ on the same porphyry using the zircon LA-ICPMS method. Nineteen Hf isotopic analyses were conducted on fifteen zircons. The $\varepsilon H f(t)$ values for the three Neoproterozoic zircons are 4.4, 11.3 and 12.8. The $\varepsilon H f(t)$ values of the Jurassic zircons range from -4.6 to 3.5 .

Tongshan syenogranite.-Eighteen U-Pb isotopic analyses were conducted on 18 zircons from the Tongshan syenogranite (09ZJ14, fig. 3R) using the SHRIMP method. Th and $\mathrm{U}$ contents are 43 to $319 \mathrm{ppm}$ and 86 to $602 \mathrm{ppm}$, respectively, with $\mathrm{Th} / \mathrm{U}=$ $0.30-0.81$. One inherited zircon has a ${ }^{206} \mathrm{~Pb} /{ }^{238} \mathrm{U}$ age of $327 \pm 9 \mathrm{Ma}$. The remaining 17 zircons yield a weighted mean ${ }^{206} \mathrm{~Pb} /{ }^{238} \mathrm{U}$ age of $133 \pm 1 \mathrm{Ma}(\mathrm{MSWD}=1.5)$. This result is consistent with the zircon SHRIMP ages (130 \pm 3 Ma and $129 \pm 2 \mathrm{Ma})$ of Jiang and others (2011) on the same pluton.

The ages of the five magmatic groups and the gaps between them are generally consistent with the age spectrum of the Mesozoic detrital zircons from a modern river (the Oujiang River) to the southeast of the study region (fig. 4B, Xu and others, 2007). The evolution trends of $\mathrm{Hf}$ isotopes are also similar, showing a rise in $\varepsilon \mathrm{Hf}(\mathrm{t})$ during the Early Cretaceous (fig. 4C).

\section{Whole-rock Major and Trace Elements}

Major elements. - The most notable feature of the major element data (table 2) is that each magmatic stage has distinct chemical compositions (fig. 5), although the samples in this study are all high-K series granitoids (fig. 5A). Based on their age and whole-rock geochemistry, five distinct groups of granitic rocks are identified. They are denoted by $\mathrm{T}_{3}$ (Late Triassic, 230-215 Ma), J2-3 (Middle-Late Jurassic, 170-150 Ma), $\mathrm{K}_{1}$ (I) (the first stage in the Early Cretaceous, 140-130 Ma), $\mathrm{K}_{1}$ (II) (the second stage in the Early Cretaceous, 130-125 Ma) and $\mathrm{K}_{1}$ (III) (the third stage in the Early Cretaceous, 115-100 Ma).

The $\mathrm{T}_{3}$ samples have moderate $\mathrm{SiO}_{2}$ contents (66-71\%) and the highest $\mathrm{K}_{2} \mathrm{O}$ contents amongst all the Mesozoic samples (fig. 5A). Apart from the Jingju syenogranite, they tend to have molar $\mathrm{Al}_{2} \mathrm{O}_{3} /\left(\mathrm{CaO}+\mathrm{Na}_{2} \mathrm{O}+\mathrm{K}_{2} \mathrm{O}\right)>1.05$ and molar $\mathrm{K}_{2} \mathrm{O} /$ $\mathrm{Na}_{2} \mathrm{O}$ ratios $>1$ (fig. 5B). A lower $\mathrm{A} / \mathrm{CNK}$ ratio for the Jingju syenogranite is associated with the occurrence of amphibole. The Suichang and Wengshan syenogranites have moderate $\mathrm{FeO}_{\text {total }} /\left(\mathrm{MgO}+\mathrm{FeO}_{\text {total }}\right)$ ratios $(\sim 0.8)$. The Jingju syenogranite has much higher $\mathrm{Fe} / \mathrm{Mg}$ ratios and also higher $\mathrm{K}_{2} \mathrm{O}$ contents. The $\mathrm{T}_{3}$ samples mainly plot in the field of ferroan granitic rocks in figure $5 \mathrm{C}$.

Similar to the $\mathrm{T}_{3}$ samples, the $\mathrm{J}_{2-3}$ samples have moderate $\mathrm{SiO}_{2}$ contents $(65-73 \%)$; however, their $\mathrm{K}_{2} \mathrm{O}$ contents and $\mathrm{FeO}_{\text {total }} /\left(\mathrm{FeO}_{\text {total }}+\mathrm{MgO}\right)$ ratios are lower. Apart from one analysis from the Tongcun porphyry, all the Jurassic samples plot in the field of magnesian granitic rocks (fig. 5C).

The $\mathrm{K}_{1}$ (I) samples mostly have high $\mathrm{SiO}_{2}$ contents (>73\%, fig. 5A). The molar $\mathrm{Al}_{2} \mathrm{O}_{3} /\left(\mathrm{CaO}+\mathrm{Na}_{2} \mathrm{O}+\mathrm{K}_{2} \mathrm{O}\right)$ ratios are around unity with most results ranging from 1 to 1.05 , which is consistent with their mineral assemblage being mostly quartz and feldspar. Molar $\mathrm{K}_{2} \mathrm{O} / \mathrm{Na}_{2} \mathrm{O}$ ratios are generally less than unity and $\mathrm{K}_{2} \mathrm{O}$ contents in most samples are less than 5 percent. They are ferroan granites with $\mathrm{FeO}_{\text {total }} /$ $\left(\mathrm{FeO}_{\text {total }}+\mathrm{MgO}\right)$ ratios $>0.8$, which are the highest among all the five groups.

The $\mathrm{K}_{1}$ (II) samples have moderate to high $\mathrm{SiO}_{2}$ contents (64-78\%). The majority of samples have $\mathrm{K}_{2} \mathrm{O}>5$ percent but highly fractionated samples from the Baijuhuajian pluton have relatively low $\mathrm{K}_{2} \mathrm{O}$ contents (4-5\%). Their molar $\mathrm{Al}_{2} \mathrm{O}_{3} /(\mathrm{CaO}+$ $\left.\mathrm{Na}_{2} \mathrm{O}+\mathrm{K}_{2} \mathrm{O}\right)$ and $\mathrm{K}_{2} \mathrm{O} / \mathrm{Na}_{2} \mathrm{O}$ ratios are scattered. They are ferroan granites with $\mathrm{FeO}_{\text {total }} /\left(\mathrm{FeO}_{\text {total }}+\mathrm{MgO}\right)$ ratios $>0.8$.

The $\mathrm{K}_{1}$ (III) samples have variable $\mathrm{SiO}_{2}$ contents (57-72\%). The molar $\mathrm{Al}_{2} \mathrm{O}_{3} /$ $\left(\mathrm{CaO}+\mathrm{Na}_{2} \mathrm{O}+\mathrm{K}_{2} \mathrm{O}\right)$ ratios are between 0.85 and 1.05 , but generally less than 1 . The molar $\mathrm{K}_{2} \mathrm{O} / \mathrm{Na}_{2} \mathrm{O}$ ratios are lower than unity. $\mathrm{K}_{2} \mathrm{O}$ contents (4-6\%) are comparable to 
TABLE 2

Whole-rock major (wt.\%) and trace element (ppm) analytical results

\begin{tabular}{|c|c|c|c|c|c|c|c|}
\hline \multirow[t]{2}{*}{$\begin{array}{c}\text { Age } \\
\text { Sample }\end{array}$} & \multirow{2}{*}{$\begin{array}{c}225 \mathrm{Ma} \\
\text { Sheyang } \\
\text { syenogranite } \\
\text { 10ZJS135 }\end{array}$} & \multirow{2}{*}{$\begin{array}{c}157 \mathrm{Ma} \\
\text { Shangsanzhi } \\
\text { porphyry } \\
\text { 10ZJS149 } \\
\end{array}$} & \multirow{2}{*}{$\begin{array}{c}136 \mathrm{Ma} \\
\text { Sucun } \\
\text { syenogranite } \\
\text { 10ZJS108 } \\
\end{array}$} & \multirow{2}{*}{$\begin{array}{c}134 \mathrm{Ma} \\
\text { Yingcun } \\
\text { porphyry } \\
10 Z J S 129 \\
\end{array}$} & \multirow{2}{*}{$\begin{array}{c}\text { 134 Ma } \\
\text { Lingkeng } \\
\text { syenogranite } \\
\text { 10ZJS136 } \\
\end{array}$} & \multicolumn{2}{|c|}{$\begin{array}{c}133 \mathrm{Ma} \\
\text { Tongshan } \\
\text { syenogranite }\end{array}$} \\
\hline & & & & & & 09ZJ13 & 09ZJ14 \\
\hline $\mathrm{SiO}_{2}$ & 67.64 & 68.43 & 75.36 & 70.22 & 74.44 & 76.05 & 76.1 \\
\hline $\mathrm{TiO}_{2}$ & 0.52 & 0.34 & 0.14 & 0.36 & 0.21 & 0.11 & 0.16 \\
\hline $\mathrm{Al}_{2} \mathrm{O}_{3}$ & 14.97 & 14.56 & 12.25 & 14.16 & 12.84 & 12.38 & 12.67 \\
\hline $\mathrm{Fe}_{2} \mathrm{O}_{3} \mathrm{t}$ & 3.75 & 1.31 & 1.55 & 2.95 & 1.76 & 1.13 & 1.43 \\
\hline $\mathrm{MnO}$ & 0.06 & 0.03 & 0.04 & 0.06 & 0.04 & 0.02 & 0.02 \\
\hline $\mathrm{MgO}$ & 0.73 & 0.62 & 0.01 & 0.55 & 0.21 & 0.08 & 0.23 \\
\hline $\mathrm{CaO}$ & 1.48 & 2.69 & 0.63 & 1.6 & 0.74 & 0.5 & 0.13 \\
\hline $\mathrm{Na}_{2} \mathrm{O}$ & 2.9 & 2.65 & 3.43 & 3.52 & 3.53 & 3.33 & 2.98 \\
\hline $\mathrm{K}_{2} \mathrm{O}$ & 6.03 & 4.98 & 5.41 & 5.17 & 5.12 & 5.61 & 5.14 \\
\hline $\mathrm{P}_{2} \mathrm{O}_{5}$ & 0.16 & 0.1 & 0.01 & 0.11 & 0.06 & 0.02 & 0.03 \\
\hline LOI & 1.64 & 3.85 & 0.9 & 0.82 & 0.76 & 0.58 & 0.91 \\
\hline Total & 99.88 & 99.56 & 99.73 & 99.53 & 99.72 & 99.8 & 99.82 \\
\hline $\mathrm{Sc}$ & 6.7 & 4.4 & 4.2 & 6 & 2.8 & 2 & 3.8 \\
\hline $\mathrm{V}$ & 20.8 & 29.5 & 1.1 & 15.8 & 8.2 & 3.4 & 3.5 \\
\hline $\mathrm{Cr}$ & 3.5 & 6.65 & 0.6 & 1.75 & 0.7 & 0.74 & \\
\hline $\mathrm{Co}$ & 4.53 & 2.89 & 0.22 & 3.09 & 1.37 & 0.68 & 4 \\
\hline $\mathrm{Ni}$ & 2.1 & 2.8 & 0.3 & 0.8 & 0.4 & & \\
\hline $\mathrm{Cu}$ & 6 & 3.5 & 2.1 & 4 & 1.2 & 2.2 & \\
\hline $\mathrm{Zn}$ & 70 & 22 & 26 & 54.1 & 20 & 14.5 & \\
\hline $\mathrm{Ga}$ & 22.3 & 20.2 & 21 & 19 & 18.8 & 18.6 & 18.5 \\
\hline $\mathrm{Rb}$ & 193 & 93.6 & 347 & 204 & 342 & 352 & 212 \\
\hline $\mathrm{Sr}$ & 302 & 312 & 20.9 & 255 & 134 & 23.2 & 83 \\
\hline $\mathrm{Y}$ & 27 & 7.3 & 60 & 38.1 & 50 & 93.1 & 30.8 \\
\hline $\mathrm{Zr}$ & 385 & 146 & 223 & 260 & 160 & 82 & 138 \\
\hline $\mathrm{Nb}$ & 21.3 & 6.6 & 37.5 & 20.9 & 31.4 & 43.6 & 20.8 \\
\hline $\mathrm{Cs}$ & 5.47 & 4.76 & 2.2 & 2.56 & 3.08 & 5.34 & 2.09 \\
\hline $\mathrm{Ba}$ & 962 & 828 & 38 & 673 & 356 & 97 & 438 \\
\hline $\mathrm{La}$ & 122 & 27.7 & 69.5 & 79.6 & 40.7 & 22.1 & 28.2 \\
\hline $\mathrm{Ce}$ & 227 & 50.6 & 138 & 143 & 77 & 49.4 & 58.1 \\
\hline $\operatorname{Pr}$ & 27.2 & 5.65 & 16.4 & 15.7 & 8.9 & 6.37 & 7.66 \\
\hline $\mathrm{Nd}$ & 87.7 & 20.1 & 58.7 & 56 & 32.2 & 25.1 & 31.2 \\
\hline $\mathrm{Sm}$ & 14.26 & 3.26 & 12.78 & 9.9 & 7.19 & 7.24 & 7.02 \\
\hline $\mathrm{Eu}$ & 1.87 & 0.91 & 0.13 & 1.3 & 0.61 & 0.28 & 0.41 \\
\hline $\mathrm{Gd}$ & 10.2 & 2.44 & 11.3 & 8.42 & 7 & 8.4 & 6.7 \\
\hline $\mathrm{Tb}$ & 1.21 & 0.3 & 1.79 & 1.21 & 1.21 & 1.69 & 1.04 \\
\hline Dy & 5.4 & 1.43 & 10.5 & 6.61 & 7.4 & 11.8 & 5.86 \\
\hline Ho & 0.96 & 0.26 & 1.96 & 1.27 & 1.54 & 2.66 & 1.1 \\
\hline Er & 2.67 & 0.63 & 5.9 & 3.7 & 4.64 & 8.6 & 3.01 \\
\hline $\mathrm{Tm}$ & 0.33 & 0.092 & 0.86 & 0.53 & 0.76 & 1.52 & 0.41 \\
\hline $\mathrm{Yb}$ & 2.29 & 0.57 & 6.09 & 3.68 & 5.48 & 10.3 & 2.67 \\
\hline $\mathrm{Lu}$ & 0.32 & 0.078 & 0.84 & 0.54 & 0.79 & 1.67 & 0.4 \\
\hline $\mathrm{Hf}$ & 9.9 & 4.01 & 8.3 & 7.34 & 5.6 & 4.05 & 5.56 \\
\hline $\mathrm{Ta}$ & 1 & 0.45 & 2.8 & 1.45 & 3.1 & 4.89 & 1.72 \\
\hline $\mathrm{Pb}$ & 32.7 & 13.3 & 37.9 & 27 & 21.3 & 30.1 & 42.2 \\
\hline $\mathrm{Th}$ & 36.8 & 9.47 & 42.5 & 27.6 & 38.1 & 29.4 & 26.85 \\
\hline $\mathrm{U}$ & 5 & 2.45 & 10.8 & 3.12 & 7.2 & 14 & 3.78 \\
\hline
\end{tabular}


TABle 2

(continued)

\begin{tabular}{|c|c|c|c|c|c|c|c|}
\hline \multirow[t]{2}{*}{$\begin{array}{c}\text { Age } \\
\text { Sample }\end{array}$} & \multirow{2}{*}{$\begin{array}{c}133 \mathrm{Ma} \\
\text { Tongshan } \\
\text { syenogranite } \\
\text { 09ZJ15 } \\
\end{array}$} & \multicolumn{3}{|c|}{$\begin{array}{c}133 \mathrm{Ma} \\
\text { Wangcun } \\
\text { syenogranite }\end{array}$} & \multirow{2}{*}{$\begin{array}{c}132 \mathrm{Ma} \\
\text { Huangkang } \\
\text { syenogranite } \\
\text { 10ZJS109 } \\
\end{array}$} & \multirow{2}{*}{$\begin{array}{c}130 \mathrm{Ma} \\
\text { Shanghekou } \\
\text { syenogranite } \\
\text { 10ZJS104 }\end{array}$} & \multirow{2}{*}{$\begin{array}{c}129 \mathrm{Ma} \\
\text { Luojia } \\
\text { porphyry } \\
\text { 10ZJS133 } \\
\end{array}$} \\
\hline & & 10ZJS119 & 10ZJS121 & 10ZJS122 & & & \\
\hline $\mathrm{SiO}_{2}$ & 74.06 & 69.82 & 69.85 & 73.86 & 73.38 & 75.79 & 74.09 \\
\hline $\mathrm{TiO}_{2}$ & 0.18 & 0.45 & 0.44 & 0.24 & 0.22 & 0.09 & 0.28 \\
\hline $\mathrm{Al}_{2} \mathrm{O}_{3}$ & 12.6 & 14.44 & 14.37 & 12.88 & 12.6 & 12.75 & 12.1 \\
\hline $\mathrm{Fe}_{2} \mathrm{O}_{3} \mathrm{t}$ & 1.65 & 3.51 & 3.42 & 1.86 & 1.9 & 1.2 & 2.65 \\
\hline $\mathrm{MnO}$ & 0.05 & 0.05 & 0.04 & 0.05 & 0.05 & 0.05 & 0.07 \\
\hline $\mathrm{MgO}$ & 0.09 & 0.6 & 0.45 & 0.14 & 0.27 & 0 & 0.13 \\
\hline $\mathrm{CaO}$ & 0.7 & 0.34 & 0.32 & 0.45 & 0.92 & 0.49 & 0.35 \\
\hline $\mathrm{Na}_{2} \mathrm{O}$ & 3.56 & 3.61 & 3.61 & 2.38 & 3.58 & 4.22 & 3.25 \\
\hline $\mathrm{K}_{2} \mathrm{O}$ & 4.84 & 5.46 & 5.67 & 6.41 & 4.68 & 4.62 & 5.08 \\
\hline $\mathrm{P}_{2} \mathrm{O}_{5}$ & 0.04 & 0.14 & 0.13 & 0.07 & 0.06 & 0.01 & 0.04 \\
\hline LOI & 1.98 & 1.35 & 1.44 & 1.26 & 2.04 & 0.61 & 1.56 \\
\hline Total & 99.75 & 99.75 & 99.73 & 99.61 & 99.71 & 99.83 & 99.58 \\
\hline $\mathrm{Sc}$ & 1.9 & 7.1 & 6.7 & 3.4 & 2.9 & 1.7 & 3.1 \\
\hline $\mathrm{V}$ & 6.9 & 20.1 & 20.1 & 7.5 & 8.1 & 0.6 & 4.8 \\
\hline $\mathrm{Cr}$ & & 2.4 & 1.8 & 0.8 & 0.8 & 0.6 & 1.1 \\
\hline $\mathrm{Co}$ & 1.8 & 3.71 & 2.97 & 1.62 & 1.51 & 0.1 & 1.2 \\
\hline $\mathrm{Ni}$ & & 1.4 & 0.8 & 0.5 & 0.5 & 0.3 & 0.7 \\
\hline $\mathrm{Cu}$ & & 7.2 & 4.4 & 3.9 & 1.8 & 1.1 & 3 \\
\hline $\mathrm{Zn}$ & & 67 & 65 & 63 & 26 & 31 & 103 \\
\hline $\mathrm{Ga}$ & 17.9 & 18.9 & 18.5 & 17.5 & 18.8 & 23.1 & 25.4 \\
\hline $\mathrm{Rb}$ & 295 & 203 & 207 & 299 & 322 & 484 & 248 \\
\hline $\mathrm{Sr}$ & 33 & 177 & 202 & 86.8 & 132 & 4.9 & 54.3 \\
\hline $\mathrm{Y}$ & 40.1 & 48 & 25 & 38 & 58 & 92 & 75 \\
\hline $\mathrm{Zr}$ & 130 & 258 & 267 & 202 & 169 & 126 & 441 \\
\hline $\mathrm{Nb}$ & 20.6 & 20.3 & 20.4 & 22.6 & 42.8 & 62.1 & 52.8 \\
\hline Cs & 9.81 & 2.42 & 2.87 & 4.38 & 3.85 & 3.32 & 1.51 \\
\hline $\mathrm{Ba}$ & 83 & 887 & 768 & 497 & 322 & 5 & 183 \\
\hline $\mathrm{La}$ & 29.7 & 121 & 55.6 & 67.4 & 46.5 & 12.7 & 130 \\
\hline $\mathrm{Ce}$ & 66.3 & 152 & 95 & 117 & 87 & 39 & 244 \\
\hline $\operatorname{Pr}$ & 8.46 & 24.7 & 11.7 & 13.2 & 10.2 & 5.7 & 29.9 \\
\hline $\mathrm{Nd}$ & 31.9 & 80.7 & 41.1 & 46.1 & 37.4 & 24.4 & 98.6 \\
\hline $\mathrm{Sm}$ & 6.88 & 14.32 & 7.34 & 8.54 & 8.54 & 9.45 & 18.12 \\
\hline $\mathrm{Eu}$ & 0.25 & 2.22 & 0.98 & 0.86 & 0.6 & 0.042 & 0.62 \\
\hline $\mathrm{Gd}$ & 6.55 & 12.2 & 5.6 & 7.4 & 8 & 10.5 & 15.4 \\
\hline $\mathrm{Tb}$ & 1.21 & 1.73 & 0.82 & 1.09 & 1.42 & 2.05 & 2.33 \\
\hline Dy & 7.44 & 9 & 4.6 & 6.1 & 8.8 & 13.8 & 13.1 \\
\hline Ho & 1.54 & 1.58 & 0.85 & 1.17 & 1.82 & 2.76 & 2.55 \\
\hline $\mathrm{Er}$ & 4.87 & 4.56 & 2.71 & 3.61 & 5.82 & 8.83 & 7.48 \\
\hline $\mathrm{Tm}$ & 0.8 & 0.61 & 0.4 & 0.53 & 0.95 & 1.39 & 1.07 \\
\hline $\mathrm{Yb}$ & 5.54 & 4.03 & 2.75 & 3.77 & 6.59 & 10.04 & 7.38 \\
\hline $\mathrm{Lu}$ & 0.875 & 0.56 & 0.4 & 0.54 & 0.96 & 1.47 & 1.05 \\
\hline Hf & 5.81 & 7 & 7.3 & 6.2 & 6.2 & 8.2 & 12.7 \\
\hline $\mathrm{Ta}$ & 2.57 & 1.3 & 1.4 & 1.8 & 4.2 & 4.9 & 3.3 \\
\hline $\mathrm{Pb}$ & 25.7 & 29 & 23.9 & 35.7 & 24.3 & 45.3 & 29.2 \\
\hline $\mathrm{Th}$ & 34.69 & 23.7 & 26.4 & 32.3 & 42.3 & 48.1 & 39.9 \\
\hline $\mathrm{U}$ & 6.63 & 3.2 & 3.3 & 4.4 & 11.5 & 8.3 & 6.6 \\
\hline
\end{tabular}


TABLE 2

(continued)

\begin{tabular}{|c|c|c|c|c|c|c|c|c|}
\hline \multirow[t]{2}{*}{$\begin{array}{c}\text { Age } \\
\text { Sample }\end{array}$} & \multicolumn{6}{|c|}{$\begin{array}{c}110 \sim 112 \mathrm{Ma} \\
\text { Muchen } \\
\text { Complex }\end{array}$} & \multicolumn{2}{|c|}{$\begin{array}{c}102 \mathrm{Ma} \\
\text { Matou } \\
\text { monzogranite }\end{array}$} \\
\hline & 10ZJS-115 & -116 & -124 & -125 & -131 & -132 & 10ZJS099 & 10ZJS101 \\
\hline $\mathrm{SiO}_{2}$ & 52.22 & 65.63 & 60.75 & 72.18 & 62.1 & 68.45 & 67.03 & 67.05 \\
\hline $\mathrm{TiO}_{2}$ & 1.13 & 0.41 & 0.82 & 0.2 & 0.64 & 0.29 & 0.56 & 0.58 \\
\hline $\mathrm{Al}_{2} \mathrm{O}_{3}$ & 17.1 & 16.25 & 17.31 & 13.6 & 16.06 & 14.8 & 15.5 & 15.71 \\
\hline $\mathrm{Fe}_{2} \mathrm{O}_{3} \mathrm{t}$ & 9.74 & 3.93 & 5.01 & 2.25 & 5.33 & 3.77 & 3.44 & 3.56 \\
\hline $\mathrm{MnO}$ & 0.21 & 0.11 & 0.1 & 0.09 & 0.13 & 0.1 & 0.1 & 0.09 \\
\hline $\mathrm{MgO}$ & 3.72 & 0.87 & 1.1 & 0.22 & 1.87 & 0.48 & 1.01 & 1.14 \\
\hline $\mathrm{CaO}$ & 7.29 & 2.11 & 2.34 & 0.63 & 3.8 & 1.17 & 2.39 & 2.7 \\
\hline $\mathrm{Na}_{2} \mathrm{O}$ & 3.82 & 4.17 & 4.73 & 3.85 & 3.59 & 4.15 & 4.15 & 3.96 \\
\hline $\mathrm{K}_{2} \mathrm{O}$ & 3.41 & 5.71 & 5.67 & 5.58 & 5.08 & 5.93 & 4.17 & 4.32 \\
\hline $\mathrm{P}_{2} \mathrm{O}_{5}$ & 0.71 & 0.2 & 0.3 & 0.06 & 0.34 & 0.12 & 0.21 & 0.21 \\
\hline LOI & 0.91 & 0.53 & 1.7 & 1 & 0.7 & 0.74 & 1.38 & 0.57 \\
\hline Total & 100.25 & 99.92 & 99.85 & 99.66 & 99.64 & 100 & 99.93 & 99.88 \\
\hline $\mathrm{Sc}$ & 15.7 & 4.3 & 8 & 2.2 & 9.1 & 2.9 & 4.8 & 5.1 \\
\hline $\mathrm{V}$ & 202 & 41.9 & 34.1 & 8.8 & 95.6 & 21.4 & 49 & 52.1 \\
\hline $\mathrm{Cr}$ & 1.54 & 0.9 & 2 & 0.6 & 6.3 & 1.5 & 3.5 & 3.7 \\
\hline $\mathrm{Co}$ & 22.5 & 5.17 & 5.07 & 1.37 & 11.4 & 3.4 & 4.62 & 5.65 \\
\hline $\mathrm{Ni}$ & 3.8 & 0.8 & 1.1 & 0.4 & 5 & 1 & 2.6 & 3.6 \\
\hline $\mathrm{Cu}$ & 35.5 & 3.7 & 6.9 & 3.6 & 16.9 & 3.8 & 8.7 & 5.7 \\
\hline $\mathrm{Zn}$ & 108 & 61 & 75 & 86 & 74 & 61 & 59 & 49 \\
\hline $\mathrm{Ga}$ & 18.4 & 18.8 & 19.4 & 19.7 & 17.9 & 17.9 & 18.5 & 19.8 \\
\hline $\mathrm{Rb}$ & 207 & 219 & 160 & 298 & 215 & 240 & 144 & 147 \\
\hline $\mathrm{Sr}$ & 968 & 463 & 607 & 164 & 591 & 366 & 538 & 618 \\
\hline $\mathrm{Y}$ & 27.4 & 35 & 24 & 55 & 30 & 33 & 15 & 14 \\
\hline $\mathrm{Zr}$ & 283 & 239 & 249 & 261 & 230 & 271 & 166 & 209 \\
\hline $\mathrm{Nb}$ & 11.8 & 25.1 & 22.2 & 53.4 & 24.1 & 20.5 & 15.4 & 16.5 \\
\hline Cs & 11.9 & 3.44 & 2.17 & 2.02 & 4.49 & 3.45 & 3.55 & 2.05 \\
\hline $\mathrm{Ba}$ & 635 & 572 & 1416 & 222 & 514 & 518 & 973 & 931 \\
\hline $\mathrm{La}$ & 37.3 & 69.6 & 46.9 & 82.3 & 47.9 & 54.6 & 44 & 63.1 \\
\hline $\mathrm{Ce}$ & 69.9 & 120 & 82 & 155 & 87 & 95 & 81 & 100 \\
\hline $\operatorname{Pr}$ & 8.73 & 13.3 & 9.6 & 17.8 & 9.9 & 10.8 & 8.9 & 10.3 \\
\hline $\mathrm{Nd}$ & 36.7 & 46.4 & 37.4 & 61.3 & 37 & 38.9 & 31.8 & 34.5 \\
\hline $\mathrm{Sm}$ & 7.81 & 8.44 & 7.29 & 11.3 & 7.03 & 7.04 & 5.32 & 5.32 \\
\hline $\mathrm{Eu}$ & 2.38 & 1.31 & 2.54 & 0.5 & 1.51 & 1.01 & 1.32 & 1.31 \\
\hline $\mathrm{Gd}$ & 7.11 & 7.2 & 6.1 & 9.5 & 6.1 & 6.3 & 4.3 & 4.3 \\
\hline $\mathrm{Tb}$ & 1 & 1.05 & 0.87 & 1.49 & 0.91 & 0.94 & 0.59 & 0.55 \\
\hline Dy & 5.3 & 5.9 & 4.7 & 8.6 & 4.9 & 5.3 & 3 & 2.7 \\
\hline Ho & 0.93 & 1.12 & 0.88 & 1.73 & 0.94 & 1.08 & 0.56 & 0.52 \\
\hline $\mathrm{Er}$ & 2.74 & 3.54 & 2.58 & 5.38 & 2.87 & 3.35 & 1.71 & 1.55 \\
\hline $\mathrm{Tm}$ & 0.37 & 0.54 & 0.37 & 0.84 & 0.42 & 0.51 & 0.24 & 0.22 \\
\hline $\mathrm{Yb}$ & 2.42 & 3.76 & 2.59 & 6.19 & 3.22 & 3.89 & 1.73 & 1.68 \\
\hline $\mathrm{Lu}$ & 0.35 & 0.55 & 0.39 & 0.95 & 0.48 & 0.59 & 0.24 & 0.27 \\
\hline $\mathrm{Hf}$ & 6.36 & 6.5 & 5.8 & 9.2 & 6.4 & 7.9 & 4.5 & 5.7 \\
\hline $\mathrm{Ta}$ & 0.78 & 1.8 & 1.2 & 3.6 & 1.9 & 1.6 & 1.1 & 1.2 \\
\hline $\mathrm{Pb}$ & 26.7 & 21 & 19.7 & 34.6 & 20.3 & 18.8 & 23.8 & 21.8 \\
\hline $\mathrm{Th}$ & 8.42 & 19.5 & 8.53 & 43.6 & 19.9 & 26.7 & 17.2 & 26 \\
\hline $\mathrm{U}$ & 2.46 & 4.1 & 1.4 & 6.9 & 3.8 & 5.1 & 2.9 & 4.2 \\
\hline
\end{tabular}



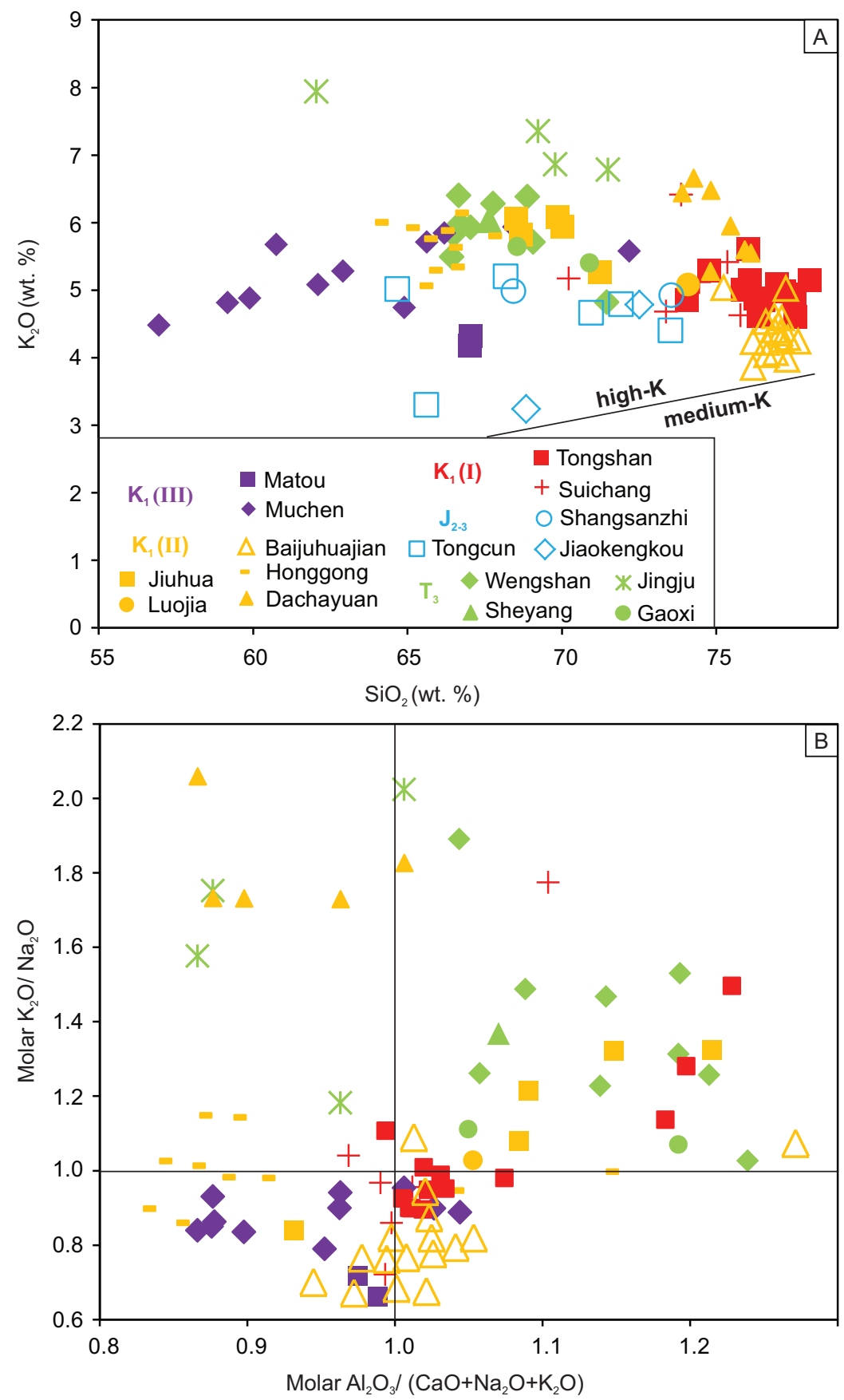

Fig. 5. Whole-rock geochemical results for the Mesozoic samples from western Zhejiang Province. All results use the same symbols as in figure $5 \mathrm{~A}$ and "+" (Suichang) represents the $\mathrm{K}_{1}(\mathrm{I})$ samples from the Lingkeng, Huangkang, Sucun, Shanghekou, Yingcun and Wangcun intrusions: (A) $\mathrm{K}_{2} \mathrm{O}$ versus $\mathrm{SiO}_{2}$; (B) molar $\mathrm{K}_{2} \mathrm{O} / \mathrm{Na}_{2} \mathrm{O}$ and $\mathrm{Al}_{2} \mathrm{O}_{3} /\left(\mathrm{CaO}+\mathrm{Na}_{2} \mathrm{O}+\mathrm{K}_{2} \mathrm{O}\right)$; 

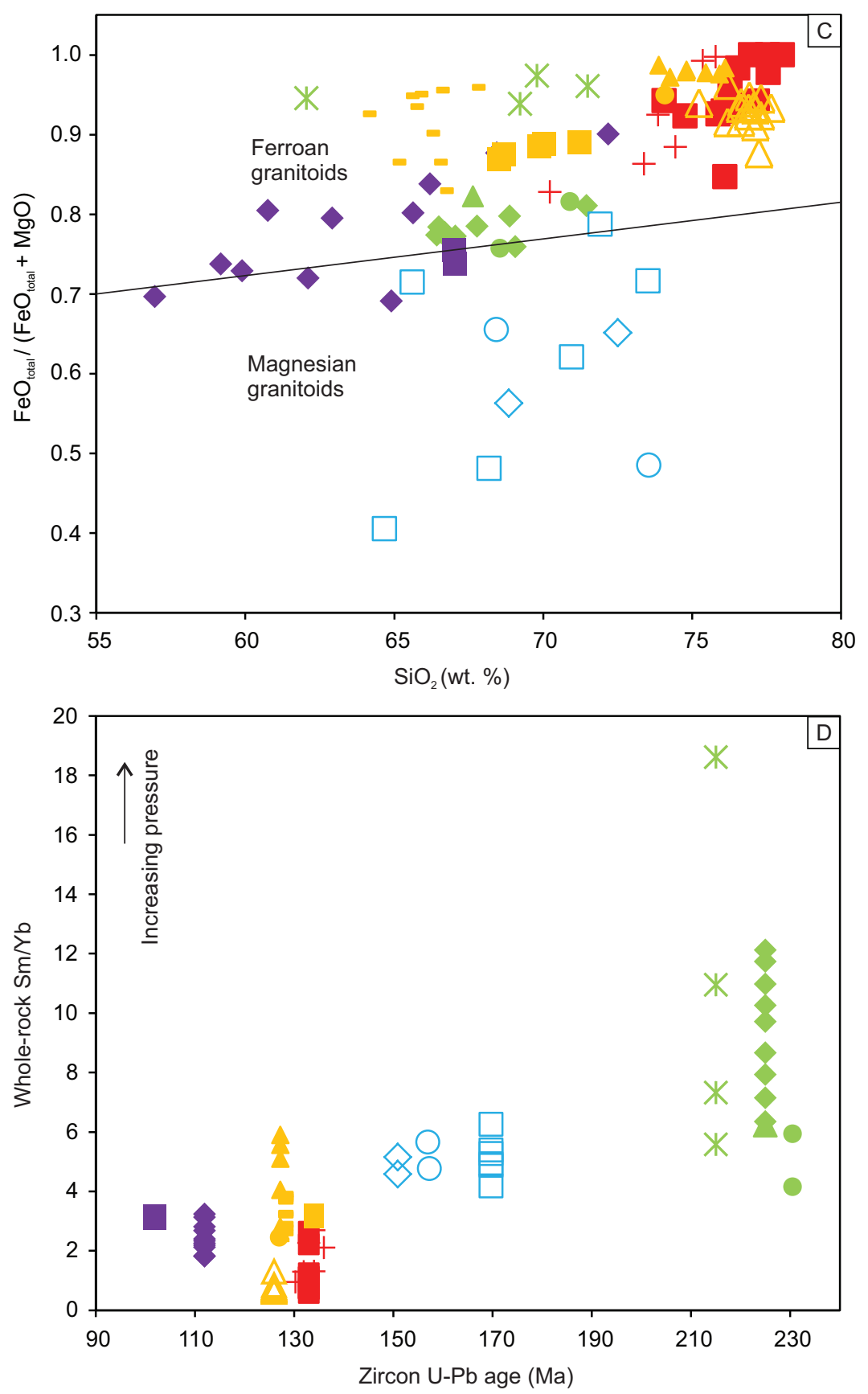

Fig. 5 (continued). (C) $\mathrm{FeO}_{\text {total }} /\left(\mathrm{FeO}_{\text {total }}+\mathrm{MgO}\right)$ versus $\mathrm{SiO}_{2}$, after Frost and others (2011); (D) $\mathrm{Sm} / \mathrm{Yb}$ ratio versus age;

$\mathrm{J}_{2-3}$ and $\mathrm{K}_{1}$ (I) samples, but lower than $\mathrm{T}_{3}$ and $\mathrm{K}_{1}$ (II) samples. On the $\mathrm{FeO}_{\text {total }} /$ $\left(\mathrm{FeO}_{\text {total }}+\mathrm{MgO}\right)$ versus $\mathrm{SiO}_{2}$ diagram, they straddle the boundary between ferroan and magnesian rocks (fig. 5C). 


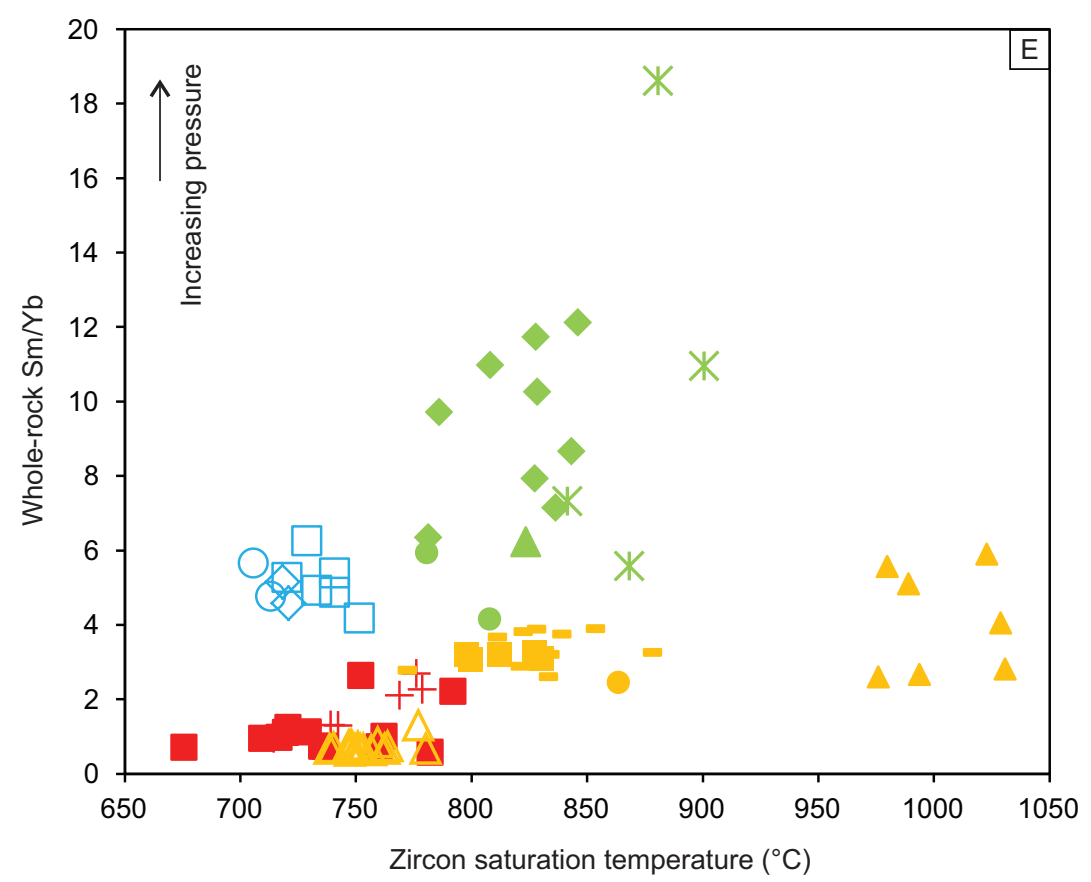

Fig. 5 (continued). (E) $\mathrm{Sm} / \mathrm{Yb}$ ratio versus zircon saturation temperatures, based on Boehnke and others (2013), excluding the mantle-derived $\mathrm{K}_{1}$ (III) rocks and assuming $\mathrm{M}=1.6$ (Miller and others, 2003) for the altered $\mathrm{J}_{2-3}$ samples.

Trace elements. - The whole-rock trace element analytical results are listed in table 2. Like major element results, each age group has a distinctive trace element pattern (fig. 6). The results are normalized to the global average upper continental crust (UCC, Rudnick and Gao, 2003), in groups of large ion lithophile elements, rare earth elements, high field strength elements and transition metal elements. The most significant differences in trace element compositions among the five groups are in REE, Ba, Sr, Eu, HFSE elements (Nb, Ta, Zr, Hf) and V/Co. All five groups have lower transition metal contents than the global average of continental upper crust. In addition, there are $\mathrm{Ni}$ and $\mathrm{Cr}$ depletions relative to other transition metal elements. Such a "W" shape pattern in the normalized diagrams has been explained by high binding energies of $\mathrm{Ni}$ and $\mathrm{Cr}$ in the ferromagnesian minerals (Allègre and Michard, 1974). From the Triassic to Early Cretaceous, there is a general decreasing trend in the $\mathrm{Sm} / \mathrm{Yb}$ ratio (fig. 5D).

For the $\mathrm{T}_{3}$ samples (fig. $6 \mathrm{~A}$ ), $\mathrm{Ba}, \mathrm{Sr}, \mathrm{Eu}, \mathrm{U}$ and $\mathrm{Pb}$ are depleted, but LREE, Th, Hf and $\mathrm{Zr}$ are relatively enriched. LREE/HREE ratios are the highest among all 5 groups, with $\mathrm{Sm} / \mathrm{Yb}=5-12$. Their $\mathrm{Ga} / \mathrm{Al}$ ratios are 2.8 to 3.5. Cr and $\mathrm{Ni}$ are depleted relative to other transition metal elements, with $(\mathrm{V} / \mathrm{Co})_{\mathrm{UCC}}=\sim 1$.

The $\mathrm{J}_{2-3}$ samples (fig. 6B) are also enriched in LREE relative to HREE, with $\mathrm{Sm} / \mathrm{Yb}=4-7$. They have the lowest REE contents among all the five groups. Both the Tongcun and Shangsanzhi samples show positive Eu anomalies. One sample from the Shangsanzhi porphry has $\mathrm{Ga} / \mathrm{Al}=2.6$. There is enrichment in $\mathrm{V}$, with $(\mathrm{V} / \mathrm{Co})_{\mathrm{UCC}}>1$. These trace element results are consistent with those reported by Chen (2011) for the Shangsanzhi porphyry.

The $\mathrm{K}_{1}$ (I) samples (fig. 6C) are strongly depleted in $\mathrm{Ba}, \mathrm{Sr}, \mathrm{Eu}, \mathrm{Zr}$, Hf and transition metals, but have high contents of $\mathrm{Rb}, \mathrm{Th}, \mathrm{U}, \mathrm{Pb}, \mathrm{Nb}$ and $\mathrm{Ta}$. They are also 

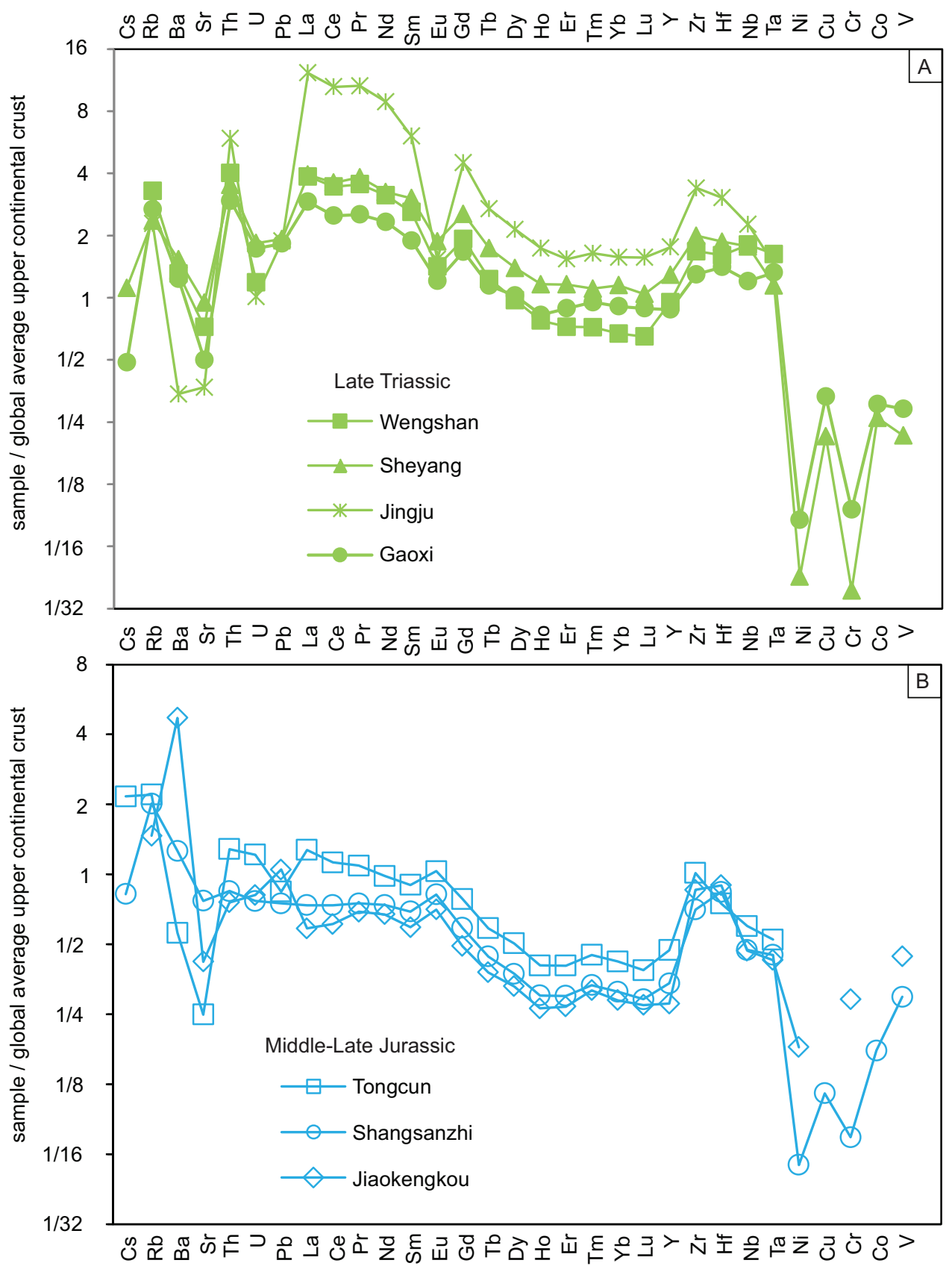

Fig. 6. Trace element patterns of the Mesozoic granitic samples from western Zhejiang Province, normalized to the global average continental upper crust (Rudnick and Gao, 2003). All data represent average composition. (A) $\mathrm{T}_{3}$ granites; (B) $\mathrm{J}_{2-3}$ porphyries;

enriched in HREE relative to LREE and MREE, with $\mathrm{Sm} / \mathrm{Yb}<3$. The samples from the Tongshan syenogranite and the Shanghekou porphyry show notably depletions in LREE. $(\mathrm{V} / \mathrm{Co})_{\mathrm{UCC}}$ values are $\sim 1$. They have $\mathrm{Ga} / \mathrm{Al}$ ratios of 2.4 to 6.4. 

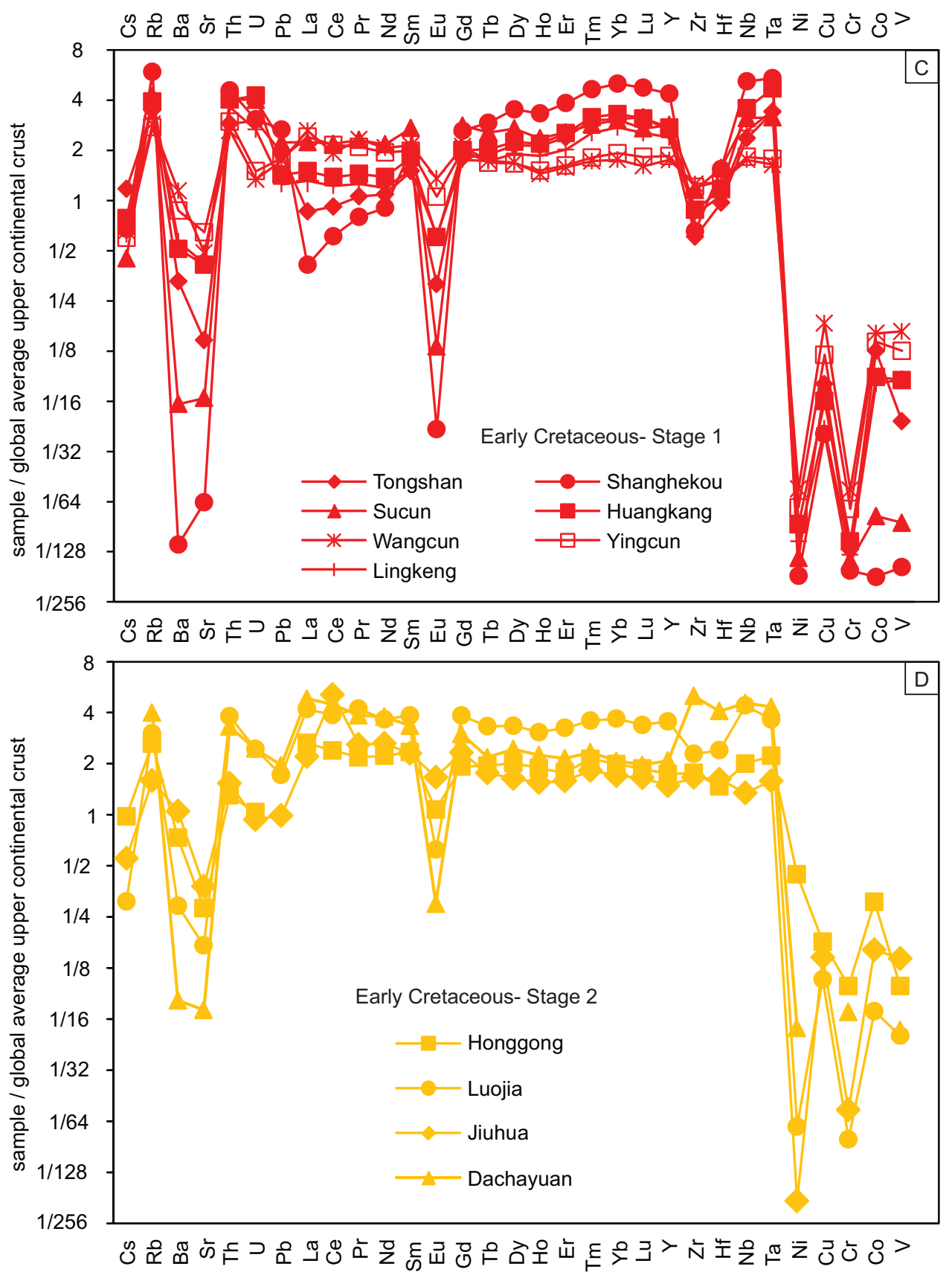

Fig. 6 (continued). (C) $\mathrm{K}_{1}$ (I) granitic rocks; (D) $\mathrm{K}_{1}$ (II) porphyries;

The $\mathrm{K}_{1}$ (II) samples (fig. 6D) have flat REE patterns, with $\mathrm{Sm} / \mathrm{Yb}=2-4$ and they are depleted in $\mathrm{Ba}, \mathrm{Sr}$ and $\mathrm{Eu}$. Their $\mathrm{Ga} / \mathrm{Al}$ ratios are 2.1 to 4.3. Relative to the $\mathrm{K}_{1}$ (I) samples, they have higher $\mathrm{Zr}$ and $\mathrm{Hf}$ but lower $\mathrm{Nb}$ and $\mathrm{Ta}$ contents, which reflect 

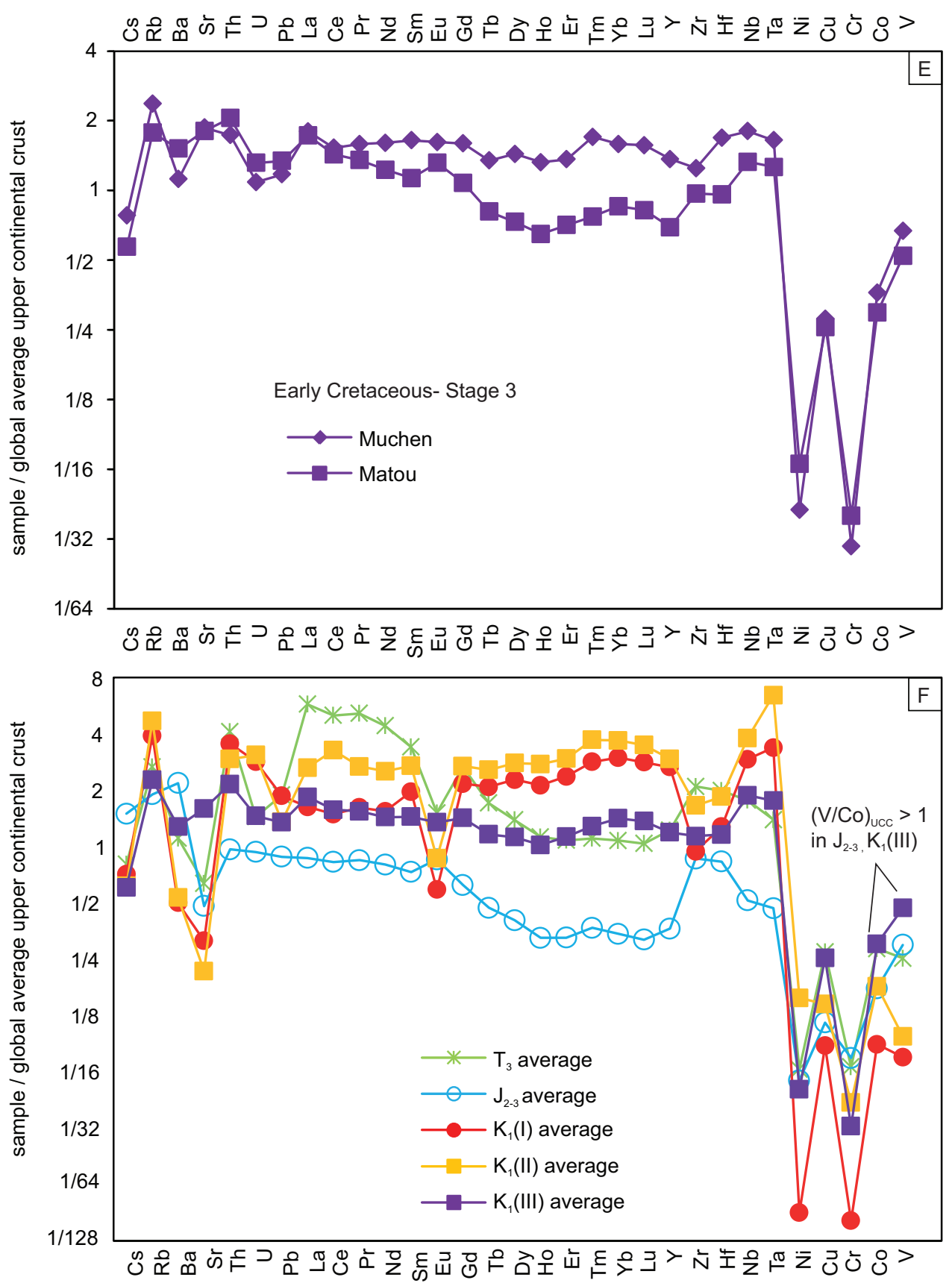

Fig. 6 (continued). (E) $\mathrm{K}_{1}$ (III) granites; (F) A comparison of the average of the different stages.

different geochemical behavior of the high field strength elements. $(\mathrm{V} / \mathrm{Co})_{\mathrm{UCC}}$ values are less than 1.

The $\mathrm{K}_{1}$ (III) samples (fig. 6E) show flat trace element patterns, similar to those of the $\mathrm{J}_{2-3}$ samples. The contents of most trace elements are comparable to those of the 
global average upper continental crust and their $\mathrm{Sm} / \mathrm{Yb}$ ratios are between 2 and 4 . Their $\mathrm{Ga} / \mathrm{Al}$ ratios are the lowest amongst the five groups (2.1-2.7). These samples also have the highest contents of transition metal elements among the five groups. Like the $\mathrm{J}_{2-3}$ samples, the $\mathrm{K}_{1}$ (III) samples are enriched in $\mathrm{V}$, with $(\mathrm{V} / \mathrm{Co})_{\mathrm{UCC}}>1$.

DISCUSSION

\section{Petrogenetic Constraints}

The five geochemically distinct groups of granitic rocks (figs. 5 and 6) in western Zhejiang Province can be distinguished based on their ages, which range from the Triassic to the Early Cretaceous (fig. 4A). The different isotopic and elemental compositions of the five groups reflect different source-temperature-pressure-waterredox conditions in the continental lithosphere. In the following discussion, the sources are constrained by zircon Hf isotopes. Figures $4 \mathrm{~A}$ and $4 \mathrm{C}$ show that the granitoids in the northwest of the study region have $\varepsilon H f(t)>-5$, which is significantly higher than those from the southeast part of the study region-the Cathaysia Block (as low as -30 ). The data support the interpretation that the basement rocks of the two regions are mainly of Neoproterozoic ( $\mathrm{Li}$ and others, 2009) and Paleoproterozoic (Yu and others, 2009) age, respectively.

Water content in granitic magmas will affect the stability of certain mafic minerals, such as amphibole and titanite (Richards, 2011) and the solubility of plagioclase (especially the An component) (Conrad and others, 1988), therefore controlling the trace element patterns (Bachmann and Bergantz, 2008).

The initial magma temperatures of the samples are estimated by zircon saturation geothermometry (Watson, 1979; Boehnke and others, 2013). The $\mathrm{J}_{2-3}$ samples have low $\mathrm{Zr}$ contents but still have inherited zircons (an average of 1/4 of the total analyzed grains for the three porphyries; Zeng and others, 2013; Li and others, 2013a; fig. 3Q of this study). Their magmas were therefore likely to be wet and cold (Miller and others, 2003). The zircon saturation thermometry may thus overestimate the initial magma temperatures of these rocks.

In contrast, inherited zircons are rarely found in the $\mathrm{T}_{3}, \mathrm{~K}_{1}(\mathrm{I})$ and $\mathrm{K}_{1}$ (II) samples. The $\mathrm{T}_{3}$ and $\mathrm{K}_{1}$ (II) rocks have high $\mathrm{Zr}$ contents: 200 to $780 \mathrm{ppm}$ and 270 to $1140 \mathrm{ppm}$, respectively. Such high values imply that zircons in the source regions probably approached complete dissolution and the zircon saturation temperatures either approximate or slightly underestimate the initial temperatures of crustal melts (see fig. 4 of Miller and others, 2003). The $\mathrm{K}_{1}(\mathrm{I})$ rocks have low $\mathrm{Zr}$ contents $(80-280 \mathrm{ppm})$ and low-temperature geochemical characteristics (low $\mathrm{MgO}, \mathrm{Ba}, \mathrm{Sr}, \mathrm{Eu}$ and transition metal contents; fig. 6C), and therefore the $\mathrm{K}_{1}(\mathrm{I})$ magmas should have initially been saturated in zircon. The zircon saturation temperatures for the $\mathrm{K}_{1}(\mathrm{I})$ magmas are therefore reasonable estimations of initial magma temperatures. The $\mathrm{K}_{1}$ (III) magmas, especially the basic (MME) and intermediate ones, were most likely zirconundersaturated mantle-derived magmas, and the zircon saturation temperatures would therefore significantly underestimate the initial magma temperatures.

The MREE/HREE ratio is regarded as a relatively reliable index of melting/ fractionation pressures for magmas, as it is mainly controlled by the proportion of residual garnet (Qian and Hermann, 2013). Although garnet can be stable as a peritectic product in melts from sedimentary sources at relatively low pressures, high contents of peritectic garnet and high magma $\mathrm{Sm} / \mathrm{Yb}$ ratios still imply high pressures (Vielzeuf and Montel, 1994). An extensive data set from the Andes shows that the maximum value of the MREE/HREE ratio is a good indicator of crustal thickness (Mamani and others, 2010). Few Mesozoic S-type granitoids in South China have high $\mathrm{Sm} / \mathrm{Yb}$ ratios (Qi and others, 2007; Wang and others, 2007; Huang and others, 2011). In the study region, all the Triassic samples have high $\mathrm{Sm} / \mathrm{Yb}$ ratios, whereas all the 
$\mathrm{K}_{1}$ (I) samples that share similar $\varepsilon \mathrm{Hf}(\mathrm{t})$ values (fig. $4 \mathrm{~A}$ ) have much lower $\mathrm{Sm} / \mathrm{Yb}$ ratios (fig. 5D). Such variations cannot be accounted for by differences in the magma sources. We have therefore used the $\mathrm{Sm} / \mathrm{Yb}$ ratio to qualitatively constrain the melting pressures for the $\mathrm{T}_{3}, \mathrm{~J}_{2-3}$ and $\mathrm{K}_{1}(\mathrm{I}-\mathrm{II})$ samples, and the fractionation pressures for $\mathrm{K}_{1}$ (III) samples (see further discussion below on partial melting/fractional crystallization).

The ratio of a pair of transition metal elements ( $\mathrm{V}$ and Co) is used for redox condition estimation. The partition coefficient of $\mathrm{V}$ in major ferromagnesian minerals significantly decreases with oxygen fugacity (Shervais, 1982). In contrast, with $\mathrm{E}^{\circ}\left(\mathrm{Co}^{3+}, \mathrm{Co}^{2+}\right)=+1.92 \mathrm{~V}$, cobalt is expected to be divalent in most geological environments (p. 665, Goldschmidt, 1958; p. 27-A-4, Wedepohl, 1973) and is a compatible element in high-temperature ferromagnesian silicate minerals.

Late Triassic magmatism: $T_{3}$. - The high $\mathrm{Sm} / \mathrm{Yb}$ ratios of the Late Triassic granites (4-19; fig. 5D), based on the estimation of Kay and Mpodozis (2001), probably reflect high melting pressures and a crustal thickeness of approximately 45 to $50 \mathrm{~km}$. The granites of this stage are mainly strongly peraluminous (fig. 5B), which is a common characteristic of dehydration melts (Patiño Douce and Beard, 1995). They are depleted in $\mathrm{Sr}$ and $\mathrm{Eu}$ (fig. 6A), reflecting the low solubility of plagioclase under water-deficient conditions (Conrad and others, 1988). The high temperatures estimated for the Late Triassic granites using zircon saturation thermometry $\left(800-900{ }^{\circ} \mathrm{C}\right.$, fig. $5 \mathrm{E}$ ) are consistent with dehydration melting rather than water-fluxed melting. The $\mathrm{T}_{3}$ rocks are ferroan granites, which are generally produced in intraplate environments (Frost and Frost, 2008). For the 215 Ma Jingju syenogranite, the occurrence of amphibole and associated low $\mathrm{A} / \mathrm{CNK}$ ratios implies a higher melting temperature $\left(\sim 850-900{ }^{\circ} \mathrm{C}\right)$ than the earlier $\sim 225$ Ma granites $\left(\sim 800-850{ }^{\circ} \mathrm{C}\right)$, suggesting that dehydration melting was triggered by amphibole breakdown (Whitney, 1988; Beard and Lorgren, 1991). The magnetic susceptibilities of the $T_{3}$ granites are relatively low (fig. 7), suggesting that the granites were generated in relatively reducing conditions. Their negative zircon $\varepsilon \mathrm{Hf}(\mathrm{t})$ values indicate that mantle materials were not significantly involved in the melting processes and the source is likely to be the Paleoproterozoic basement (Yu and others, 2009).

The Wengshan and Jingju syenogranites were classified as aluminous A-type granites by Sun and others (2011) and Li and others (2012a), based on their high whole-rock $\mathrm{Ga} / \mathrm{Al}$ ratios (Whalen and others, 1987). Those two studies further argued that the $\mathrm{T}_{3}$ granites were generated in a transtensional tectonic setting. However, such high $\mathrm{Ga} / \mathrm{Al}$ ratios could reflect other factors rather than a lower pressure. High melting pressures under dehydration conditions result in high modal garnet (Patiño Douce and Beard, 1995) and it has been shown that Ga is notably depleted in garnet relative to plagioclase and other rock-forming minerals (DeVore, 1955; O'Hara, 1961). As a result, the melt tends to become richer in $\mathrm{Ga}$. Another factor is the relatively stable An-rich plagioclase in the source under dry melting conditions. $\mathrm{Ga}$ and $\mathrm{Al}$ both form complexes with oxygen and they are network formers for silicate minerals (Ringwood, 1955). Since the $\mathrm{Ga}$ ion has a larger radius than $\mathrm{Al}, \mathrm{GaO}_{4}{ }^{5-}$ tends to accumulate in the melt relative to $\mathrm{AlO}_{4}{ }^{5-}$ (Goldschmidt, 1958). The phenomenon can also be understood by the lower melting point of $\mathrm{NaGaSi}_{3} \mathrm{O}_{8}\left(1015^{\circ} \mathrm{C}\right.$, Goldsmith, 1950) than plagioclase. Goodman (1972) noticed that later-formed Ab-rich plagioclase has higher Ga contents than earlier-formed An-rich plagioclase, which implies that Ga tends to be scavenged by low melting point Al-bearing minerals such as Ab-rich plagioclase and alkali feldspar. Therefore, under water-deficient conditions with low An solubility and a low degree of partial melting, alkali feldspar granites and syenogranites tend to have high $\mathrm{Ga} / \mathrm{Al}$ ratios. The same explanation can be applied to the $\mathrm{K}_{1}$ (I-II) A-type granitic rocks (for example, Wong and others, 2009; Yang and others, 2013) and we argue that 


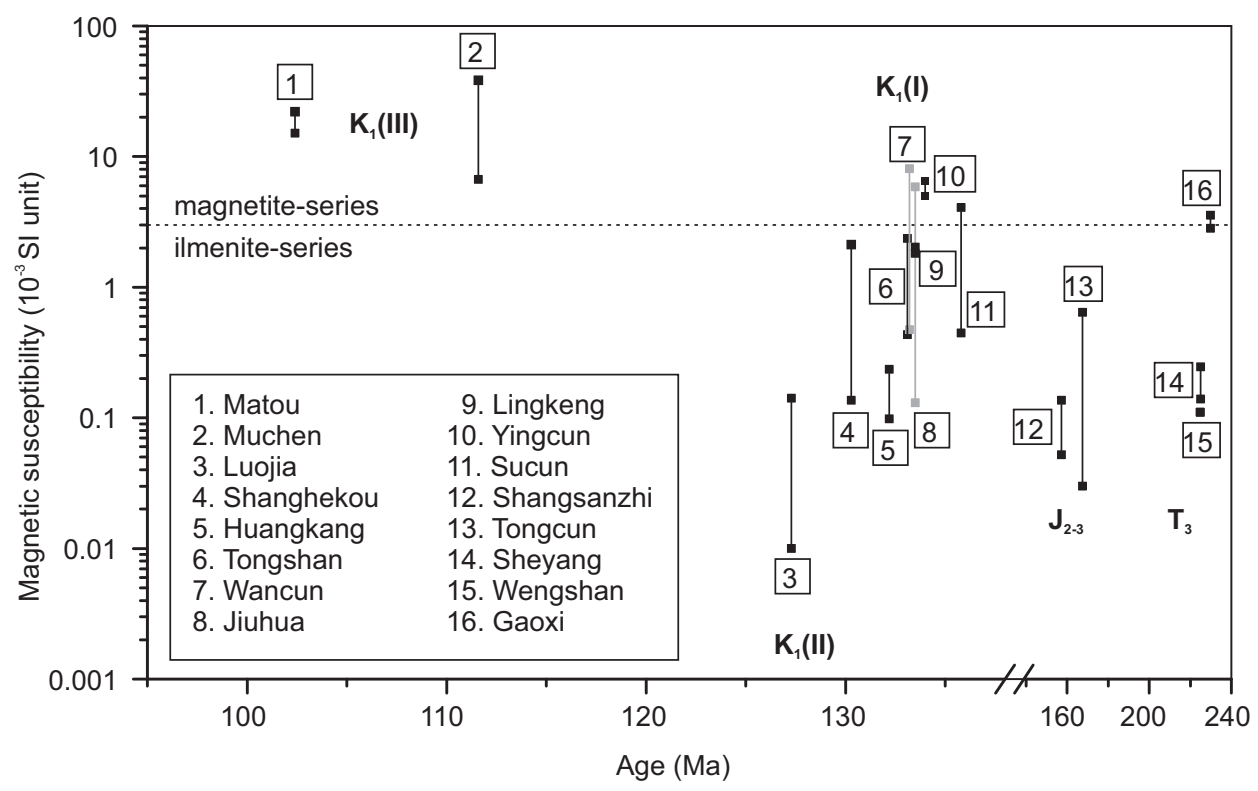

Fig. 7. Magnetic susceptibility versus age plot for the Mesozoic samples from western Zhejiang Province. The boundary between the magnetite and ilmenite series granitoids is from Ishihara and others (2000).

the $\mathrm{Ga} / \mathrm{Al}$ ratios are not relevant to the crustal melting pressure, at least in our study area. Overall, the $T_{3}$ granites were generated by high temperature and high pressure dehydration melting in a reduced lower crust.

Middle-Late Jurassic magmatism: $J_{2-3}$. - The zircon $\mathrm{Hf}$ isotope results alone cannot distinguish whether the $\mathrm{J}_{2-3}$ porphyries were derived from a metasomatic mantle, or from Neoproterozoic crustal rocks [see discussions on $\mathrm{K}_{1}$ (III) samples and fig. 3Q]. However, the prophyries have low zircon saturation temperatures (fig. 5E) and many inherited Neoproterozoic zircons (Li and others, 2013a; Zeng and others, 2013), and therefore more likely represent crust-derived granitic melts saturated in zirconium (Miller and others, 2003). This is consistent with the low Ti-in-zircon temperatures of the Tongcun porphyries $\left(<781^{\circ} \mathrm{C}\right.$, Qiu and others, 2013).

No mafic enclaves and coeval mafic rocks have been found associated with the $\mathrm{J}_{2-3}$ intrusions, and there is no evidence for any direct involvement of mantle-derived magmas in the genesis of the $\mathrm{J}_{2-3}$ granitic porphyries. The fact that the $\mathrm{J}_{2-3}$ granitic porphyries are Mo-bearing also implies they were most likely generated from a crust that had a much higher content of Mo than the mantle (Palme and O'Neill, 2003). The $\mathrm{Sm} / \mathrm{Yb}$ ratios of the Jurassic porphyries are lower than for the Triassic granites, but still higher than the Cretaceous ones (fig. 5E), suggesting that these granitic porphyries were also generated in thickened crust. A high water flux would be required to generate such low-temperature melts from the Neoproterozoic materials in a thickened lower crust.

The properties of the $\mathrm{J}_{2-3}$ granitic porphyries suggest that the melting processes involved high contents of water and high oxygen fugacities. For example, these porphyries are not depleted in Eu and are magnesian rocks that are typical products of wet arc environments (Frost and others, 2011). Also, their low $\mathrm{Zr}$ contents were likely caused by water-fluxed melting processes. Their trace element patterns resemble those of felsic rocks produced in a cold-wet-oxidized environment (Bachmann and Bergantz, 
2008). These rocks have porphyritic textures, which were possibly controlled by high water contents and earlier water saturation because "crystallization under vaporsaturated conditions will cause a shorter temperature range and finer grain size" (Whitney, 1988). As Qiu and others (2013) reported for the Tongcun porphyry, there are no $\mathrm{Eu}$ anomalies in the zircon $\mathrm{REE}$ patterns, which indicate a high $\mathrm{Eu}^{3+} / \mathrm{Eu}^{2+}$ ratio in the magma and therefore a highly oxidized environment during zircon crystallization. $\log \left(f \mathrm{O}_{2}\right)$ is $\mathrm{FMQ}+2.7$ based on the zircon Ce anomaly, which is much higher than that of the $\mathrm{K}_{1}(\mathrm{I})$ samples, for example, the Shangjieshou porphyry with FMQ - 1.1 (Qiu and others, 2013). A high V/Co ratio is observed in the Shangsanzhi porphyry that was likely generated from water-fluxed melting. However, in the $\mathrm{T}_{3}$ granites formed by dehydration melting, this signature is less obvious or absent. Such a high $\mathrm{V} / \mathrm{Co}$ ratio reflects a relatively oxidized condition that lowered the partition coefficients of $\mathrm{V}$ in mafic minerals. To summarize, the results indicate that the $\mathrm{J}_{2-3}$ granites were generated at low temperatures and high pressures through water-fluxed melting in an oxidized lower crust.

First stage of Early Cretaceous magmatism: $K_{1}(I)$.- These granitic rocks are highly felsic syenogranites that are depleted in anorthite and ferromagnesian components. Strong depletions in $\mathrm{Ba}, \mathrm{Sr}$ and $\mathrm{Eu}$, and the impoverishment in transition metal elements, imply low temperatures and/or depletion in volatile components. They belong to the ferroan granitic rocks, which are typically generated in intraplate environments. The decreased V/Co ratios and significantly increased REE contents relative to the $\mathrm{J}_{2-3}$ porphyries also imply a reduced and water-deficient melting environment (Bachmann and Bergantz, 2008). The A-type affinities (high whole-rock $\mathrm{Ga} / \mathrm{Al}$ ratios) of the $\mathrm{K}_{1}(\mathrm{I})$ granitic rocks were likely caused by the low-degree dehydration melting at relatively low temperatures $\left(700-800{ }^{\circ} \mathrm{C}\right.$, fig. $\left.5 \mathrm{E}\right)$. The low LREE/HREE ratios of the $\mathrm{K}_{1}(\mathrm{I})$ granitic rocks can be interpreted as a result of low-pressure partial melting. Low $\mathrm{Sm} / \mathrm{Yb}$ ratios (fig. $5 \mathrm{E}$ ) are generally linked to a thin crust (Kay and Mpodozis, 2001; Mamani and others, 2010), where garnet is unstable and does not fractionate rare earth elements. Since feldspars are important hosts for LREE during partial melting (Villaseca and others, 2007), the depletion of feldspar components (table 1) in low-pressure melts (Tuttle and Bowen, 1958; Gualda and Ghiorso, 2013) will also cause relative LREE depletion.

Samples from the Tongshan syenogranite and the Shanghekou porphyry are notably depleted in LREE. Miller and Mittlefehldt (1982) attributed such a phenomenon to the fractionation of LREE-rich minerals: notably monazite or allanite. Since both minerals contain considerable amounts of $\mathrm{Th}$, their fractionation will not only deplete LREE but also Th. We did not find such results within individual intrusions or between intrusions. We note that low LREE content is associated with low $\mathrm{Ba}, \mathrm{Sr}, \mathrm{Eu}, \mathrm{Zr}$ and transition metals (fig. 6C). All these elements are generally depleted in lowtemperature granitic melts. Because the beryllium-feldspar component tends to be stable as a solid phase at low temperature (Rankama and Sahama, 1950), the substitution of $\mathrm{K}^{+}\left(\mathrm{Na}^{+}\right)-\mathrm{Si}^{4+}$ by $\mathrm{LREE}^{3+}-\mathrm{Be}^{2+}$ will cause LREE depletion. Therefore, we interpret the low LREE property of some $\mathrm{K}_{1}(\mathrm{I})$ granitic rocks as being mainly caused by low magma temperatures.

It has been shown that dehydration melting is responsible for producing both the $\mathrm{T}_{3}$ and $\mathrm{K}_{1}$ (I) granitic rocks, but at different temperatures and pressures. Comparing the $\mathrm{T}_{3}$ and $\mathrm{K}_{1}$ (I) samples from the Cathaysia Block, their $\varepsilon \mathrm{Hf}(\mathrm{t})$ values are comparable and therefore suggest that both were sourced from the Paleoproterozoic basement (fig. 4). It can be inferred that different melting temperatures of the $\mathrm{T}_{3}$ syenogranites and $\mathrm{K}_{1}(\mathrm{I})$ syenogranites were largely controlled by different melting depths (and thus pressures; fig. 5E). 
Overall, the results indicate that the $\mathrm{K}_{1}(\mathrm{I})$ granitic rocks were produced from low temperature and low pressure dehydration melting in a reduced lower crust.

Second stage of Early Cretaceous magmatism: $K_{1}(I)$.- - Although overlapping to some extent, the $\mathrm{K}_{1}(\mathrm{II})$ porphyries mainly formed after $130 \mathrm{Ma}$, whereas all the $\mathrm{K}_{1}(\mathrm{I})$ granitic rocks formed before $130 \mathrm{Ma}$. However, more significant are their differences in petrology, geochemistry and isotopic compositions. Except for the highly fractionated Baijuhuajian pluton, the $\mathrm{K}_{1}$ (II) porphyries have lower $\mathrm{SiO}_{2}$ and higher $\mathrm{K}_{2} \mathrm{O}$ contents than the $\mathrm{K}_{1}(\mathrm{I})$ samples. Moreover, their $\mathrm{Sm} / \mathrm{Yb}$ ratios and $\mathrm{Zr}$ contents reveal their higher melting pressures and temperatures $\left(>800{ }^{\circ} \mathrm{C}\right)$. Coeval rhyolites in this region (Yang and others, 2013) also have high $\mathrm{Zr}$ contents and indicate high temperature. Like the $\mathrm{T}_{3}$ granites, the $\mathrm{K}_{1}$ (II) porphyries contain alkali feldspar megacrysts (fig. 2). In contrast, most $K_{1}(I)$ samples show medium-grained textures.

Relative to the $\mathrm{K}_{1}(\mathrm{I})$ samples, $\mathrm{Sr}$ and $\mathrm{Eu}$ are less depleted in the $\mathrm{K}_{1}(\mathrm{II})$ samples (fig. 6D), suggesting increased solubility of the An component with temperature. Higher ferromagnesian contents and $\mathrm{Mg} / \mathrm{Fe}$ ratios also reveal their higher melting temperatures. These geochemical characteristics support the view that the $\mathrm{K}_{1}$ (II) rocks were produced through dehydration melting, but at higher temperature than the $\mathrm{K}_{1}(\mathrm{I})$ rocks. The $\mathrm{K}_{1}(\mathrm{II})$ samples have higher $\mathrm{Zr} / \mathrm{Nb}$ ratios than the $\mathrm{K}_{1}(\mathrm{I})$ samples. Although tetravalent $\mathrm{Zr}$ and $\mathrm{Hf}$ and pentavalent $\mathrm{Nb}$ and $\mathrm{Ta}$ are all high field strength elements, their geochemical behaviors are different during crustal melting. During low-temperature crustal partial melting, zircon behaves as a refractory mineral; the Nband Ta-bearing minerals, in contrast, are low melting point components in the melt. The increased $\mathrm{Zr} / \mathrm{Nb}$ ratios of the $\mathrm{K}_{1}$ (II) samples compared to the $\mathrm{K}_{1}(\mathrm{I})$ samples can be simply explained by a higher degree of partial melting at higher temperatures. Comparing the $\mathrm{T}_{3}$ and $\mathrm{K}_{1}$ (II) samples with similar $\mathrm{SiO}_{2}$ contents, we find they have similar major and trace element characteristics, except that the $\mathrm{K}_{1}$ (II) samples have lower $\mathrm{Sm} / \mathrm{Yb}$ ratios. The $\mathrm{T}_{3}$ and $\mathrm{K}_{1}$ (II) granitic rocks were likely generated at similar high temperatures but at different depths.

Another significant change that occurred during the formation of the $\mathrm{K}_{1}(\mathrm{I})$ and $\mathrm{K}_{1}$ (II) rocks is the increase of initial ${ }^{176} \mathrm{Hf} /{ }^{177} \mathrm{Hf}$ ratios (fig. $4 \mathrm{~A}$ ). The ages and $\mathrm{Hf}$ isotopes of the detrital zircons from the Cathaysia Block reveal a similar trend (fig. 4C). We attribute this to the involvement of mantle-derived materials in the source of the $\mathrm{K}_{1}$ (II) magmas.

Under high temperature conditions, enhanced zircon solubilities in the granitic melt result in high HREE contents due to high HREE contents in zircon. Relative to the $\mathrm{K}_{1}(\mathrm{I})$ rocks, the increased melting pressures of the $\mathrm{K}_{1}(\mathrm{II})$ porphyries (but not high enough to stabilize garnet) increase feldspar components in the granitic melt and therefore LREE contents. Therefore, the $\mathrm{K}_{1}$ (II) porphyries have high REE contents and flat REE patterns. Such REE characteristics (with negative anomalies in Eu) support that these rocks were hot, dry, reduced magmas (Bachmann and Bergantz, 2008). Low V/Co ratios also indicate that the sources were relatively reduced.

In summary, the $\mathrm{K}_{1}$ (II) rocks were produced from high-temperature dehydration melting in a reduced lower crust. The sources of the $\mathrm{K}_{1}(\mathrm{II})$ rocks were possibly more refractory and had more depleted $\mathrm{Hf}$ isotopic compositions than those of the $\mathrm{K}_{1}(\mathrm{I})$ rocks, suggesting mantle input during the $\mathrm{K}_{1}(\mathrm{I}-\mathrm{II})$ stage.

Third stage of Early Cretaceous magmatism: $K_{1}(I I I)$. - Geochemically, the $\mathrm{K}_{1}(\mathrm{III})$ samples bear similarities to the $\mathrm{J}_{2-3}$ samples in terms of major and trace element composition. Like the $\mathrm{J}_{2-3}$ samples, they have low $\mathrm{SiO}_{2}$ contents, high Fe-Mg-Ti contents and low $\mathrm{FeO}_{\text {total }} /\left(\mathrm{FeO}_{\text {total }}+\mathrm{MgO}\right)$ ratios. The $\mathrm{K}_{1}(\mathrm{III})$ and $\mathrm{J}_{2-3}$ samples also have subparallel trace element patterns (fig. 6). Compared with the earlier waterdeficient $\mathrm{K}_{1}$ (II) rocks (for example, the Honggong quartz syenitic porphyry and the Jiuhua porphyry, figs. $6 \mathrm{D}$ and $6 \mathrm{E}$ ), the felsic samples of the $\mathrm{K}_{1}$ (III) rocks (such as the 
Matou monzogranite) are not depleted in $\mathrm{Sr}$ and $\mathrm{Eu}$, implying an increase in magma water content from $\mathrm{K}_{1}$ (II) to $\mathrm{K}_{1}$ (III), whereby the liquidus and solidus of plagioclase decreased (Bowen, 1913; Yoder and others, 1957; Moore and Carmichael, 1998, p. 313). The stability of amphibole in these metaluminous $\mathrm{K}_{1}$ (III) granites also reflects high water contents (Naney, 1983; Annen and others, 2006; Behrens and Gaillard, 2006). Like the $\mathrm{J}_{2-3}$ granitic prophyries, the low REE contents of the $\mathrm{K}_{1}$ (III) granites likely reflect the stability of titanite and amphibole during partial melting and/or fractional crystallization in a wet and oxidized environment (Bachmann and Bergantz, 2008). Nonetheless, there is likely a source variation between the $\mathrm{J}_{2-3}$ and $\mathrm{K}_{1}$ (III) rocks because the Muchen Complex shows the rare occurrence of inherited zircons (Liu and others, 2013; this study). Therefore, most samples from the Muchen Complex were initially high-temperature, mantle-derived magmas that were undersaturated in zirconium. Also, abundant magmatic mafic enclaves are evidence for extensive involvement of mafic magmas in their genesis.

The magnetic susceptibilities of the $\mathrm{K}_{1}$ (III) samples are higher than samples from the other four stages (fig. 7). That is the case even for the highly felsic $\mathrm{K}_{1}$ (III) granites, consistent with their relatively high magnetite contents and high $\mathrm{V} / \mathrm{Co}$ ratios. Therefore, the $\mathrm{K}_{1}$ (III) granites were produced in an oxidized environment, under which the following reaction is shifted to the right-hand side (Wones, 1989): hedenbergite + ilmenite + oxygen $\leftrightarrow$ titanite + magnetite + quartz. These pieces of evidence reveal that the $\mathrm{K}_{1}$ (III) granites, like the $\mathrm{J}_{2-3}$ porphyries, were generated in a wet and oxidized environment with water-fluxed melting as the major mechanism. The $\mathrm{K}_{1}$ (III) granites have lower $\mathrm{Ga} / \mathrm{Al}$ ratios (2.1-2.7) than the other groups. Since these rocks have high An contents, the $\mathrm{Ga} / \mathrm{Al}$ ratios decrease because anorthite has a much higher $\mathrm{Al}$ content and lower Ga content than sodic plagioclase (Goodman, 1972).

In this study, the Hf isotopic analyses on zircons from samples with different $\mathrm{SiO}_{2}$ contents from the Muchen Complex give relatively uniform results (fig. 8A). Liu and others (2011) reported similar data and argued that magma differentiation was a result of mixing between crust-derived and depleted mantle-derived magmas, whereby the Hf isotopes were well mixed. Although the property of isotopic homogenization across chemical diversity is theoretically one of the fundamentals of isotope geochemistry (Allègre, 2008), the heterogeneity of zircon Hf isotopic compositions at a hand specimen scale (this study; Wong and others, 2011) reflects considerable kinetic difficulties. Therefore, the homogeneity of zircon Hf isotopic compositions in the Muchen Complex (with a scale of tens of kilometers) was unlikely caused by crust-level mixing. Most Early Cretaceous basalts in Zhejiang Province have enriched Sr-Nd isotopic compositions (Qin, ms, 2007; Cui and others, 2011) and the zircon Hf isotopic compositions of the MMEs and intermediate rocks in the Muchen Complex were likely inherited from their enriched mantle sources.

For the felsic rocks in the Muchen Complex, Liu and others (2011) noted that the zircon $\varepsilon H f(t)$ values of a quartz monzonite sample were more positive than those of the MME sample. This implies that the source of the Muchen Complex was heterogeneous and the source rock of the quartz monzonite had even more depleted Hf isotopic compositions. Noting that all the other Mesozoic granitoid samples from the Cathaysia Block have negative zircon $\varepsilon H f(t)$ values (fig. 4), it is unlikely that the quartz monzonite sample with positive zircon $\varepsilon H f(t)$ values (Liu and others, 2011) was sourced from the older lower crustal materials. The felsic samples in this study (Samples 10ZJS125 and 10ZJS132) also show more depleted Hf isotopic compositions than the older granitoids. Therefore, the felsic rocks in the Muchen Complex, like the MME and intermediate rocks, were also sourced from the oxidized and enriched mantle materials rather than the continental lower crust. 

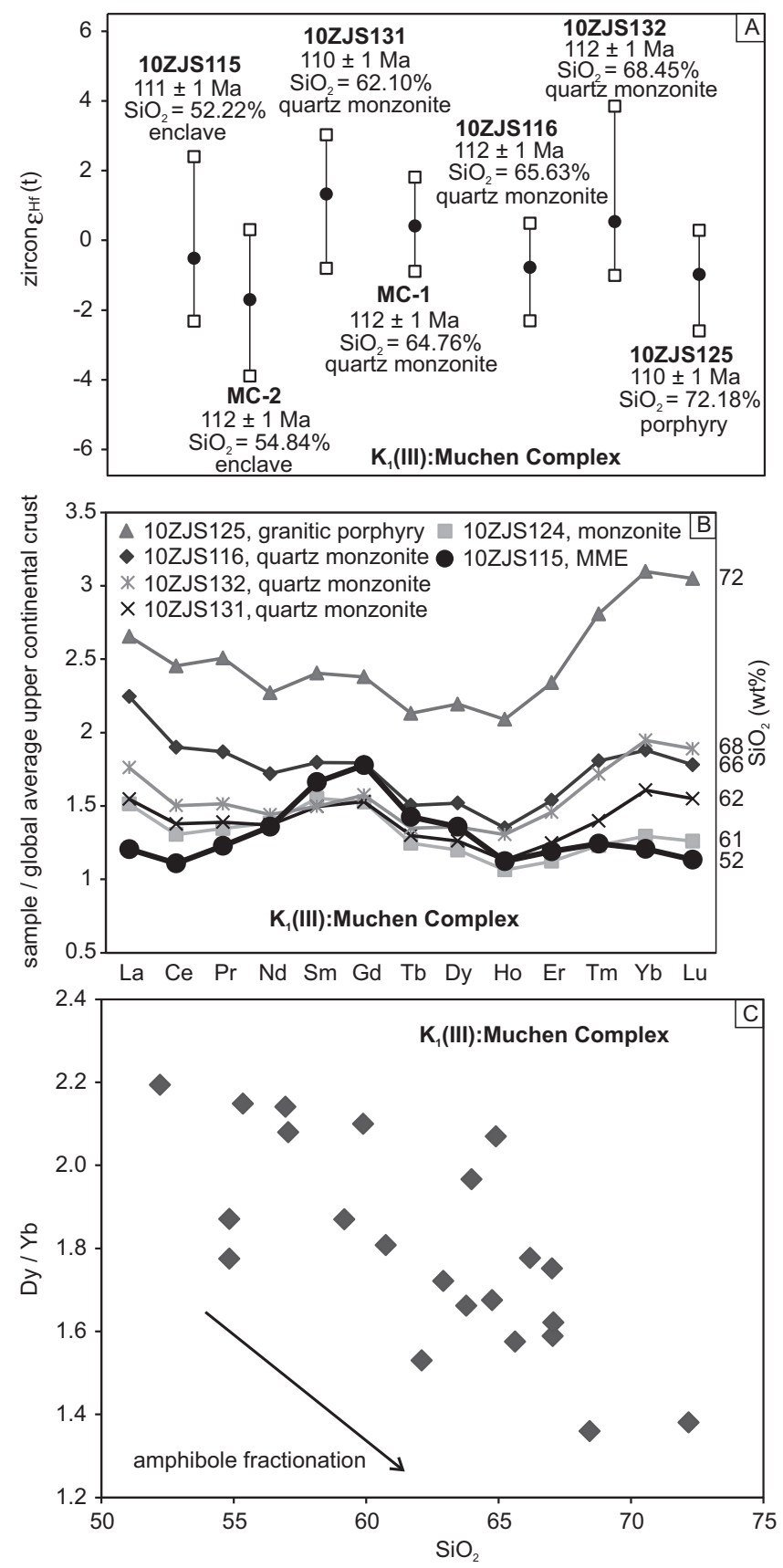

Fig. 8. (A) Zircon $\varepsilon H f(t)$ of seven samples from the Muchen Complex, with filled dots representing the average values. Samples MC-1 and MC-2 are from Liu and others (2011). Note that there is no significant change in their initial Hf isotopic compositions. (B) REE distribution patterns for the six samples in this study, showing a general increasing trend in REE contents with $\mathrm{SiO}_{2}$ and a MREE peak in the mafic enclave. (C) Whole-rock Dy/Yb versus $\mathrm{SiO}_{2}$ plot for the Muchen Complex, including all the previously published data (Lu, 2007; Liu and others, 2011; Liu and others, 2013). A decrease in Dy/ $\mathrm{Yb}$ with increasing $\mathrm{SiO}_{2}$ indicates fractional crystallization of amphibole. 
The cogenetic characteristic of the Muchen Complex is further supported by its continuous range in magnetic susceptibility and linear major element trends on Harker diagrams (Lu, 2007). Initial ${ }^{87} \mathrm{Sr} /{ }^{86} \mathrm{Sr}$ of the adjacent $105 \mathrm{Ma}$ Shangyutou basalt, the MMEs in the Muchen Complex and Muchen quartz monzonite are 0.7059, 0.7062 to 0.7065 and 0.7058 to 0.7070 , respectively; $\varepsilon N d(\mathrm{t})$ values are $-0.95,-2.6$ to -0.6 and -3.2 to -2.4 , respectively (Liu and others, 2013; Yun-Wen Yu, Zhejiang Geological Survey, 2011, personal communication). The Sr-Nd isotopic data also support a single mantle source (with some crustal contamination) for the $\mathrm{K}_{1}$ (III) basalts, MMEs and granitic rocks.

Figure $8 \mathrm{~B}$ shows that the REE patterns of the intermediate and felsic samples are subparallel but the MME sample has a significant peak of MREE compared with the other samples. If we regard the MME as closer to the primary magma composition for the Muchen Complex, this phenomenon and the decrease in the $\mathrm{Dy} / \mathrm{Yb}$ ratio with increase in $\mathrm{SiO}_{2}$ (fig. 8C) should reflect the fractionation of amphibole, which sequestered MREE (Davidson and others, 2007; Richards, 2011).

\section{Tectonic Constraints from Granitic Petrogenesis}

Below we present a case that petrogenetic results from the region can best be explained by the model of flat-slab subduction and foundering ( $\mathrm{Li}$ and $\mathrm{Li}, 2007$ ) in South China during the Mesozoic.

Triassic: crustal thickening above a flat slab.-Mesozoic magmatic rocks in southeastern South China are generally regarded as the products of paleo-Pacific plate subduction (for example, Jahn and others, 1990; Zhou and Li, 2000), although there is no consensus on when subduction started. The high-K characteristics (fig. 5A) and predominantly negative $\varepsilon \mathrm{Hf}(\mathrm{t})$ values (fig. $4 \mathrm{~A}$ ) of the Mesozoic granitoids are associated with a mature continental crust in the region, and do not support the existence of a deep sea between the Yangtze and Cathaysia blocks during the Late Permian-Early Triassic (Xiao and He, 2005). The extensive Triassic folds, thrusts and local metamorphism in the region (for example, $\mathrm{Li}$ and Li, 2007) imply a mountain-building crustal thickening event in western Zhejiang Province during that time, which generated the Late Triassic granites with high melting temperatures and high $\mathrm{Sm} / \mathrm{Yb}$ ratios. The occurrence of wet and oxidized $226 \mathrm{Ma}$ quartz monzonite implies that the orogeny was most likely caused by oceanic plate subduction (Zhu and others, 2013). However, the region was about $600 \mathrm{~km}$ from the continental margin, which is much further inland than an orogenic-magmatic belt associated with a normal continental arc (for example, the NE Honshu arc and the Sunda arc). However, it is consistent with a flat-slab or shallow-angle subduction, similar to the Peruvian and Pampean flat-slab subduction in the Andes (for example, Ramos and Folguera, 2009). The U-Pb ages, Hf isotopes and $\mathrm{O}$ isotopes of detrital zircons from the hinterland of South China support the view that Permian magmatism was caused by a normal arc along the continental margin (fig. 9A, Li and others, 2012b).

There are some fundamental differences between the flat-slab subduction (Li and Li, 2007) and shallow-angle subduction (Zhou and Li, 2000) models. One significant difference is that for flat-slab subduction, the oceanic lithosphere is coupled with the overlying continental lithosphere, dramatically reducing the conductive heat from the asthenospheric mantle and exerting a strong cooling effect on the basal continental lithosphere (Dumitru and others, 1991). Another consequence of flat-slab subduction is thickening of the overriding continental plate (fig. 9B) because of its strong coupling with the propagating flat-slab (for example, Fromm and others, 2004; Orozco and others, 2013). Regional metamorphism and crustal partial melting may therefore result.

The flat-slab subduction model can explain the petrogenesis of the Triassic granites found in the region. At the front of the flat-slab, the fluid released from the 

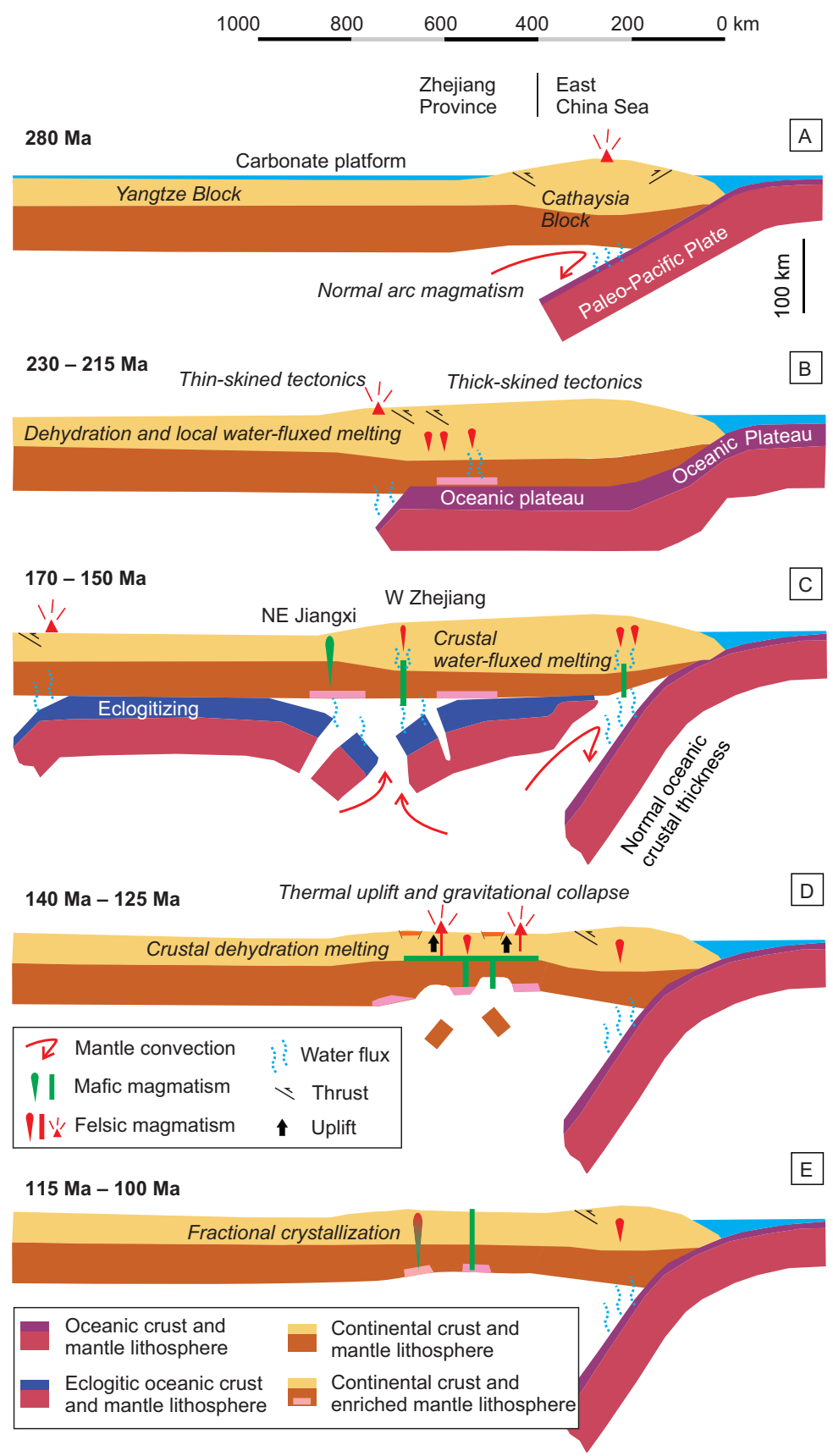

Fig. 9. Tectonic model for southeastern China during the Mesozoic, modified after Li and Li (2007) and $\mathrm{Li}$ and others (2012b). (A) Permian: normal subduction and arc magmatism (Li and others, 2006; $\mathrm{Li}$ and others, 2012b). (B) $\mathrm{T}_{3}$ : flat-slab subduction caused the thickening of the continental crust in Zhejiang Province and dehydration melting in the lower crust. Fluids and hydrous silicate melts released from the flat slab caused mantle metasomatism and some local crustal water-fluxed melting (Zhu and others, 2013). (C) $\mathrm{J}_{2-3}$ : foundering of the eclogitic flat slab caused water-fluxed melting of the oxidized and hydrous continental crust. (D) $\mathrm{K}_{1}$ (I-II): extension and, possibly delamination, of the continental lithosphere generated large amounts of felsic igneous rocks from crustal dehydration melting. (E) $\mathrm{K}_{1}$ (III): melting of the hydrous and enriched continental lithospheric mantle. 
slab could have triggered melting in the continental lithospheric mantle when it had not cooled down (fig. 9B). The 254 Ma Tieshan and 242 Ma Yangfang syenites (Wang and others, 2005b) were possibly generated by this process. The high $\mathrm{V} / \mathrm{Co}$ ratios (9.4-23.0 for the Tieshan syenite and 5.5-16.1 for the Yangfang syenite) reflect strongly oxidized environments related to the subduction process. The detrital zircon spectrum also records an Early Triassic thermal event (fig. 4C). Therefore, the front of the flat-slab likely reached the study region by the Early Triassic.

Since the overriding continental crust was thickened during flat-slab subduction, its geothermal gradient increased and Triassic regional medium- to high-grade (up to granulite facies) metamorphism occurred (Li and Li, 2007; Yu and others, 2009; Xia and others, 2012). The recrystallized rims of the zircons from some metamorphic rocks recorded almost the same age as the $T_{3}$ granites of this study, implying that both the $T_{3}$ metamorphism and granites were generated in the thickened crust, although fluids or melts from the flat-slab may have caused local metasomatism and water-fluxed melting in the lower crust (Zhu and others, 2013). Triassic high-grade metamorphism and crustal melting occurred dominantly to the southeast of the Jiang-Shao Fault (fig. 1C). To the northwest of the fault, the 280 (?) to $200 \mathrm{Ma}$ Indosinian orogenic event is shown mainly as a thin-skinned fold-and-thrust belt (for example, Xiao and He, 2005; Wang and others, 2005a; Li and Li, 2007). The fact that only the coastal belt of the Cathaysia Block (in Zhejiang and possibly Fujian provinces) recorded widespread high-grade metamorphism and partial melting supports the view that thick-skinned deformation was caused by flat-slab subduction rather than the amalgamation of the Yangtze and Cathaysia blocks (Xiao and He, 2005).

Another tectonic model for the Triassic of South China is the collision between the South China and Indochina blocks (Zhou and others, 2006). However, an oxidized continental lithosphere can be explained by flat-slab subduction, but not a continental collision over a thousand kilometers away. Some Triassic granitic rocks near the coast of South China (fig. 1A) have high V/Co ratios, such as the $226 \mathrm{Ma}$ Dashuang quartz monzonite in eastern Zhejiang Province (6.3-6.7, Zhu and others, 2013), the $226 \mathrm{Ma}$ Jintan biotite granite in central Jiangxi Province (6.4-10.5, Li, ms, 2011), the $234 \mathrm{Ma}$ and 220 Ma Guikeng granite in southern Fujian Province (6.0-20.8, Mao and others, 2011), the Triassic Dayinchang granite in northern Fujian Province (8.3-20.3, Wang and others, 2013) and the 237 Ma Qiongzhong granite in Hainan Province (5.7-23.1, Ge, ms, 2003). In contrast, thirteen Triassic granitic intrusions from Hunan Province have low and uniform V/Co ratios (5.0-6.4, Wang and others, 2007). It thus appears that the Triassic granitic rocks near the coast were more oxidized than those in the hinterland, which again can best be explained by the subduction of an oxidized oceanic plate.

Middle Jurassic: foundering of the flat slab.-Since the continental lithosphere was continually cooled down by the flat slab after the Triassic crustal melting and high-grade metamorphism, the decreasing geothermal gradient is no longer favorable to magmatism, resulting in a magmatic hiatus in the Early Jurassic. Further crustal melting did not occur until the next water-fluxing and/or heating event. During the Jurassic, the eclogitizing of oceanic crust (with oceanic plateaux) started to cause the flat slab to break up and founder ( $\mathrm{Li}$ and $\mathrm{Li}, 2007$; fig. 9C). Heat and water caused melting of the overriding continental lithosphere, with heat being provided by upwelling asthenosphere through the slab window, and the water being from the hydrous metasomatic continental lithospheric mantle and/or the foundering oceanic slab. The 170 to 150 Ma porphyries in western Zhejiang Province were mainly derived from melting of Neoproterozoic crustal rocks. In eastern Zhejiang Province, the Nd and Hf isotopes of the earlier $180 \mathrm{Ma}$ Xiepu granite (Li and others, 2012c) and the 177 Ma Maonong dacitic tuff (Liu and others, 2012) show that they were sourced from the 
Paleoproterozoic basement of the Cathaysia Block as were the Late Triassic granitoids (also see fig. 4C for detrital zircon records), and they were probably triggered by basaltic underplating following the slab break-off (Ferrari, 2004; Li and others, 2012c; Meng and others, 2012).

Early Cretaceous: lithospheric extension.-Since the Early Cretaceous, the tectonics of the South China Block is characterized by strong extension (Li, 2000; Zhou and others, 2006). In western Zhejiang Province, the extension of the lithosphere is evident from the development of the "Gan-Hang Rift" during this period, which approximately followed the Jiang-Shao Fault Zone (Gilder and others, 1991). The location of the "Gan-Hang Rift" is shown in Goodell and others (1991). The $\mathrm{K}_{1}(\mathrm{I})$ rocks in this study had lower melting pressures than their $\mathrm{T}_{3}$ and $\mathrm{J}_{2-3}$ counterparts, consistent with stronger extension during $\mathrm{K}_{1}$ time. Increased geothermal gradients in the extensional continental lithosphere, and possibly basaltic underplating, were responsible for the extensive crustal melting during $\mathrm{K}_{1}$ (I-II), with no significant addition of external water. This indicates that foundering of the flat-slab was completed by the Early Cretaceous (fig. 9D). The extensional tectonics, such as the Gan-Hang Rift and many other graben in the region, were probably promoted by two coupled mechanisms: cessation of horizontal compression due to steep subduction of the paleo-Pacific plate, and gravitation collapse following the foundering of the eclogized oceanic flat-slab (figs. 9C-9D), similar to the early Basin and Range Province in North America (Howell, 1995, p. 12; Humphreys, 2009) and the Jurassic Nanling Range in China (Li and Li, 2007). Thermal uplifting exhumed the Precambrian metamorphic rocks and Late Triassic intrusions in the region, upon which the Early Cretaceous strata were deposited.

The $\mathrm{K}_{1}$ (III) basaltic and andesitic rocks (including the MME samples) in western Zhejiang Province, such as those from the Muchen Complex and the Pujiang basaltic andesite (Qin, ms, 2007), share similar trace element patterns with those from other active continental margins, such as the Nowitna (Alaska, Moll-Stalcup and Arth, 1989), San Juan (Colorado, Lipman and others, 1978; Lipman, 1987) and Pocho (Sierras Pampeanas, Kay and Gordillo, 1994) volcanic fields in the North and East Pacific (fig. 10). There are two general models for such high-K arc-like magmas far away from the trench. One is low-angle subduction (Lipman and others, 1978); the other is melting of an enriched continental lithospheric mantle during lithospheric extension (Davis and Hawkesworth, 1993; Humphreys and others, 2003). The Early Cretaceous tectonics in South China was dominated by extension with no evidence for shallow-angle subduction. Furthermore, Hf is generally immobile during subduction-dehydration processes. The $\varepsilon H f(t)$ values of most $\mathrm{K}_{1}(\mathrm{III})$ basaltic and andesitic rocks are approximately zero or weakly negative, indicating they were unlikely sourced from the asthenospheric mantle wedge. Therefore, the second model is more realistic. TriassicEarly Jurassic flat-slab subduction likely resulted in the metasomatism of the continental lithospheric mantle, which melted and produced arc-like magmas during $\mathrm{K}_{1}$ (III) (fig. 9E), with some of these mafic magmas trapped in the cogenetic granitic magmas as enclaves. Compared to $\mathrm{J}_{2-3}$, the continental lithosphere was much hotter during $\mathrm{K}_{1}$ (III), which facilitated the fractional crystallization of mantle-derived magmas in the crust.

\section{CONCLUSIONS}

Based on a new petrogenetic analysis, we divide the Mesozoic granitic rocks of western Zhejiang Province into a five-stage evolutionary sequence, representing a typical Andean-type orogenic cycle (for example, Ramos, 2009). Our results show that the properties of granitoids are mainly determined by their sources and temperaturepressure-water-redox conditions during melting and fractionation processes.

The Late Triassic $\left(\mathrm{T}_{3}\right)$ granites in western Zhejiang Province were produced from high temperature and high pressure dehydration melting in the lower crust (fig. 9B). 


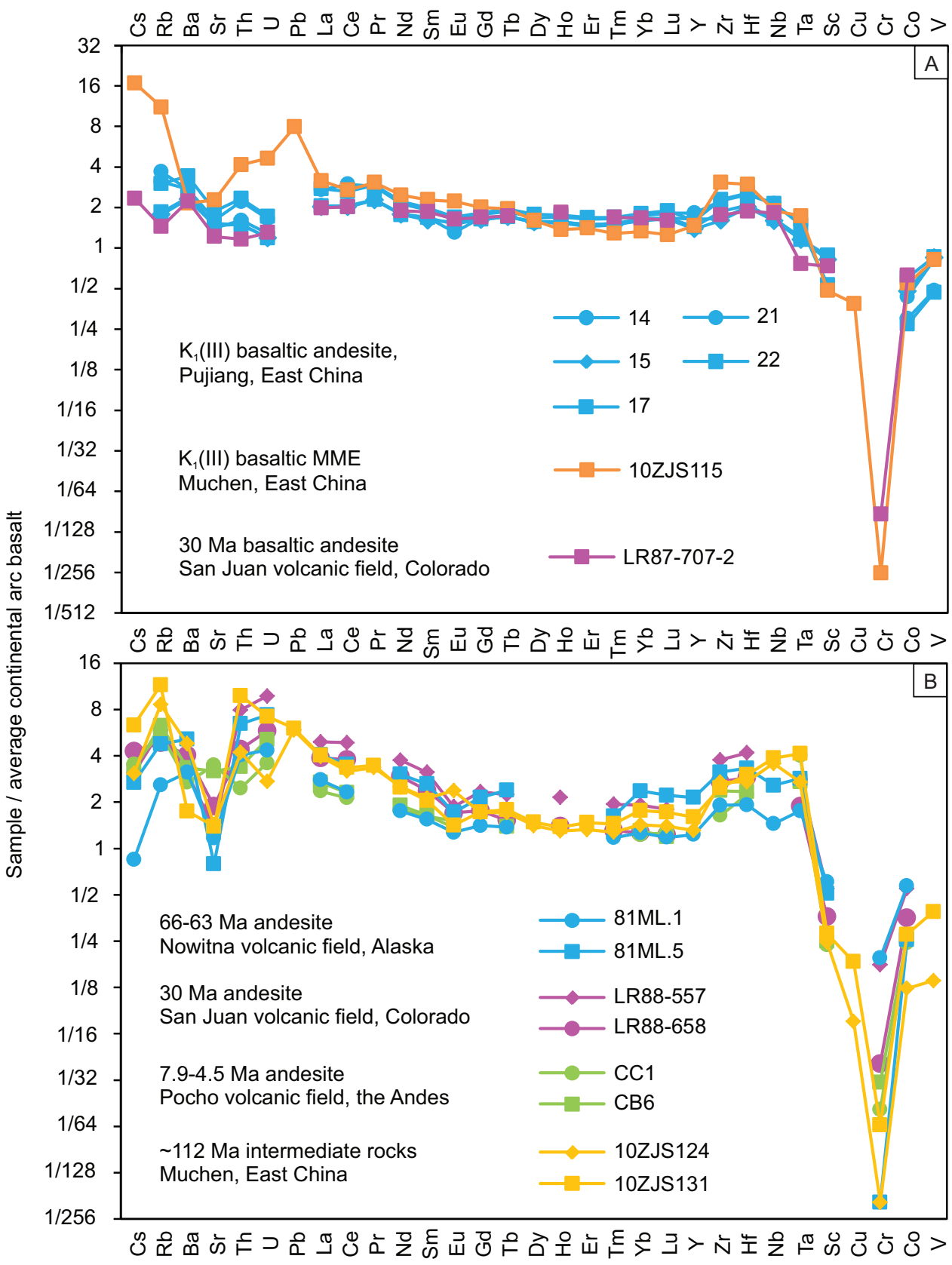

Fig. 10. Comparisons between the $\mathrm{K}_{1}$ (III) mafic (A) and intermediate (B) rocks in our study area and those from other active continental margins that likely underwent flat-slab subduction (Moll-Stalcup and Arth, 1989, Nowitna; Kay and Gordillo, 1994, Pocho; Lipman, 2004, 2006, San Juan). The data for the average continental arc basalt and Pujiang basaltic andesite are from Kelemen and others (2003) and Qin (ms, 2007), respectively.

The high pressure and high temperature were the result of crustal thickening caused by flat-slab subduction of the paleo-Pacific Plate, which cooled and metasomatised the 
continental lithosphere at the same time. The Middle and Late Jurassic $\left(\mathrm{J}_{2-3}\right)$ porphyries were generated from low temperature and high pressure water-fluxed melting of the oxidized lower crust (fig. 9C). The low temperature was caused by Triassic thermal insulation of the flat-slab prior to its foundering. Since the Early Cretaceous (figs. 9D-9E), the continental lithosphere in South China has undergone strong extension as a result of roll-back of the paleo-Pacific Plate. The first stage of granitic rocks in the Early Cretaceous $\left[\mathrm{K}_{1}(\mathrm{I})\right]$ was the result of low-temperature and low-pressure dehydration melting in the attenuated crust. The low temperatures were determined by the low pressures due to lithospheric thinning. The second stage granitic rocks in the Early Cretaceous $\left[\mathrm{K}_{1}(\mathrm{II})\right]$ were produced by similar processes to the $\mathrm{K}_{1}(\mathrm{I})$ granitic rocks, but from more refractory crustal materials. Mantle materials were possibly involved before or during the melting process. The third stage of granitic magmatism in the Early Cretaceous $\left[\mathrm{K}_{1}(\mathrm{III})\right]$ formed by fractionation of hydrous and oxidized basaltic magmas, which were generated from the subcontinental lithospheric mantle.

\section{ACKNOWLEDGMENTS}

Two anonymous reviewers provided constructive and helpful comments that significantly improved the paper. We are indebted to Wen-Tao Hong, Lei Liu, Bing Wu and Yan Xia from Nanjing University for their assistance during field work and zircon LA-ICPMS analyses; to Meng-Qun Zhang of Nanjing University for assistance with XRF analyses; to Yong-Sheng Liu of the China University of Geosciences, and Li-Ping Lin, Hai-Zhen Wei and Tao Yang of Nanjing University, for assistance with trace element analyses; to Hong-Feng Tang and Ming-Liang Wang of the Institute of Geochemistry, Chinese Academy of Sciences, and An-Jun Lin of Nanjing University, for assistance with zircon Hf analyses. Yun-Wen Yu of the Zhejiang Geological Survey kindly provided the age and geochemical data for the Shangyutou basalt. This work was financially supported by the National Basic Research Program of China (2012CB416701), the Natural Science Foundation of China (41072043) and Australian Research Council Discovery Project grant (DP110104799). This is TIGeR publication No. 493 and contribution 363 from the ARC Centre of Excellence for Core to Crust Fluid Systems (http://www.ccfs.mq.edu.au/).

\section{Appendices}

TABLE A1

http:/ / earth.geology.yale.edu/ ajs/SupplementaryData/2014/02ZhuTableA.1.docx

TABLE A2

http:/ / earth.geology.yale.edu/ ajs/SupplementaryData/2014/03ZhuTableA.2.docx

TABLE A3

http:/ / earth.geology.yale.edu/ ajs/SupplementaryData/2014/04ZhuTableA.3.docx

REFERENCES

Allègre, C. J., 2008, Isotope Geology: Cambridge, Cambridge University Press, 512 p.

Allègre, C. J., and Michard, G., 1974, Introduction to Geochemistry: Dordrecht, Boston, D. Reidel Publishing Company, 142 p.

Andersen, T., 2002, Correction of common lead in U-Pb analyses that do not report ${ }^{204} \mathrm{~Pb}$ : Chemical Geology, v. 192, n. 1-2, p. 59-79, http://dx.doi.org/10.1016/S0009-2541(02)00195-X

Annen, C., Blundy, J. D., and Sparks, R. S. J., 2006, The genesis of intermediate and silicic magmas in deep crustal hot zones: Journal of Petrology, v. 47, n. 3, p. 505-539, http://dx.doi.org/10.1093/petrology/ egi084

Bachmann, O., and Bergantz, G. W., 2008, Rhyolites and their source mushes across tectonic settings: Journal of Petrology, v. 49, n. 12, p. 2277-2285, http://dx.doi.org/10.1093/petrology/egn068

Beard, J. S., and Lorgren, G. E., 1991, Dehydration melting and water-saturated melting of basaltic and 
andesitic greenstones and amphibolites at 1, 3, and 6.9 kb: Journal of Petrology, v. 32, n. 2, p. 365-401, http://dx.doi.org/10.1093/petrology/32.2.365

Behrens, H., and Gaillard, F., 2006, Geochemical aspects of melts: Volatiles and redox behavior: Elements, v. 2, n. 5, p. 275-280, http://dx.doi.org/10.2113/gselements.2.5.275

Black, L. P., and Gulson, B. L., 1978, The age of the Mud Tank carbonatite, Strangways Range, Northern Territory: BMR Journal of Australian Geology and Geophysics, v. 3, p. 227-232.

Black, L. P., Kamo, S. L., Allen, C. M., Davis, D. W., Aleinikoff, J. N., Valley, J. W., Mundil, R., Campbell, I. H., Korsch, R. J., Williams, I. S., and Foudoulis, C., 2004, Improved ${ }^{206} \mathrm{~Pb} /{ }^{238}$ U microprobe geochronology by the monitoring of a trace-element-related matrix effect; SHRIMP, ID-TIMS, ELA-ICP-MS and oxygen isotope documentation for a series of zircon standards: Chemical Geology, v. 205, n. 1-2, p. 115-140, http://dx.doi.org/10.1016/j.chemgeo.2004.01.003

Blichert-Toft, J., and Albarède, F., 1997, The Lu-Hf isotope geochemistry of chondrites and the evolution of the mantle-crust system: Earth and Planetary Science Letters, v. 148, n. 1-2, p. 243-258, http:// dx.doi.org/10.1016/S0012-821X(97)00040-X

Boehnke, P., Watson, E. B., Trail, D., Harrison, T. M., and Schmitt, A. K., 2013, Zircon saturation re-revisited: Chemical Geology, v. 351, p. 324-334, doi:10.1016/j.chemgeo.2013.05.028, http://dx.doi.org/10.1016/ j.chemgeo.2013.05.028

Bowen, N. L., 1913, The melting phenomena of the plagioclase feldspars: American Journal of Science, Series 4, v. 35, n. 210, p. 577-599, http://dx.doi.org/10.2475/ajs.s4-35.210.577

_ 1928, The Evolution of the Igneous Rocks: Princeton, New Jersey, Princeton University Press, 332 p.

Castro, A., Moreno-Ventas, I., and de la Rosa, J. D., 1991, H-type (hybrid) granites: a proposed revision of the granite-type classification and nomenclature: Earth-Science Reviews, v. 31, n. 3-4, p. 237-253, http:// dx.doi.org/10.1016/0012-8252(91)90020-G

Chappell, B., and White, A., 1974, Two contrasting granite types: Pacific Geology, v. 8, p. 173-174.

Charvet, J., Lapierre, H., and Yu, Y.-W., 1994, Geodynamic significance of the Mesozoic volcanism of southeastern China: Journal of Southeast Asian Earth Sciences, v. 9, n. 4, p. 387-396, http://dx.doi.org/ 10.1016/0743-9547(94)90050-7

Chen, C., Lee, C., and Shinjo, R., 2008, Was there Jurassic Paleo-Pacific subduction in South China? Constraints from ${ }^{40} \mathrm{Ar} /{ }^{39} \mathrm{Ar}$ dating, elemental and $\mathrm{Sr}-\mathrm{Nd}-\mathrm{Pb}$ isotopic geochemistry of the Mesozoic basalts: Lithos, v. 106, n. 1-2, p. 83-92, http:/ /dx.doi.org/10.1016/j.lithos.2008.06.009

Chen, S.-Q., ms, 2011, Discussion on the Yangshan Epoch rock characteristics and ore-forming background in Zhejiang Kaihua region: Beijing, China University of Geosciences, M. S. thesis, 53 p (in Chinese with English abstract).

Chu, N.-C., Taylor, R. N., Chavagnac, V., Nesbitt, R. W., Boella, R. M., Milton, J. A., German, C. R., Bayon, G., and Burton, K., 2002, Hf isotope ratio analysis using multi-collector inductively coupled plasma mass spectrometry: an evaluation of isobaric interference corrections: Journal of Analytical Atomic Spectrometry, v. 17, p. 1567-1574, http://dx.doi.org/10.1039/b206707b

Conrad, W. K., Nicholls, I. A., and Wall, V. J., 1988, Water-saturated and -undersaturated melting of metaluminous and peraluminous crustal compositions at $10 \mathrm{~kb}$ : Evidence for the origin of silicic magmas in the Taupo Volcanic Zone, New Zealand, and other occurrences: Journal of Petrology, v. 29, n. 4, p. 765-803, http://dx.doi.org/10.1093/petrology/29.4.765

Cui, Y.-R., Xie, Z., Wang, B., Chen, J.-F., Yu, Y.-W., and He, J.-F., 2011, Geochemical characteristics of the Late Mesozoic basalts in Southeastern Zhejiang Province and constraints on magma source materials: Geological Journal of China Universities, v. 17, p. 492-512 (in Chinese with English abstract).

Davidson, J., Turner, S., Handley, H., Macpherson, C., and Dosseto, A., 2007, Amphibole "sponge" in arc crust?: Geology, v. 35, n. 9, p. 787-790, http://dx.doi.org/10.1130/G23637A.1

Davis, J., and Hawkesworth, C., 1993, The petrogenesis of 30-20 Ma basic and intermediate volcanics from the Mogollon-Datil Volcanic Field, New Mexico, USA: Contributions to Mineralogy and Petrology, v. 115, n. 2, p. 165-183, http://dx.doi.org/10.1007/BF00321218

DeVore, G. W., 1955, Crystal growth and the distribution of elements: The Journal of Geology, v. 63, n. 5 , p. 471-494, http://dx.doi.org/10.1086/626288

Dumitru, T. A., Gans, P. B., Foster, D. A., and Miller, E. L., 1991, Refrigeration of the western Cordilleran lithosphere during Laramide shallow-angle subduction: Geology, v. 19, n. 11, p. 1145-1148, http:// dx.doi.org/10.1130/0091-7613(1991)019〈1145:ROTWCL >2.3.CO;2

Farges, F., Ponader, C. W., Calas, G., and Brown, G. E., Jr., 1992, Structural environments of incompatible elements in silicate glass/melt systems: II. $\mathrm{U}^{\mathrm{IV}}, \mathrm{U}^{\mathrm{V}}$, and $\mathrm{U}^{\mathrm{VI}}$ : Geochimica et Cosmochimica Acta, v. 56, n. 12, p. 4205-4220, http://dx.doi.org/10.1016/0016-7037(92)90261-G

Ferrari, L., 2004, Slab detachment control on mafic volcanic pulse and mantle heterogeneity in central Mexico: Geology, v. 32, n. 1, p. 77-80, http://dx.doi.org/10.1130/G19887.1

FGS (Fujian Geological Survey), 1972, Regional Geology of Guangfeng area: Fuzhou, Bureau of Geology and Mineral Resources of Fujian Province, $289 \mathrm{p}$ (in Chinese).

Fromm, R., Zandt, G., and Beck, S. L., 2004, Crustal thickness beneath the Andes and Sierras Pampeanas at $30^{\circ} \mathrm{S}$ inferred from Pn apparent phase velocities: Geophysical Research Letters, v. 31, n. 6, L06625, http://dx.doi.org/10.1029/2003GL019231

Frost, B. R., and Frost, C. D., 2008, A geochemical classification for feldspathic igneous rocks: Journal of Petrology, v. 49, n. 11, p. 1955-1969, http://dx.doi.org/10.1093/petrology/egn054

Frost, C. D., and Frost, B. R., 2011, On ferroan (A-type) granites: their compositional variability and modes of origin: Journal of Petrology, v. 52, n. 1, p. 39-53, http://dx.doi.org/10.1093/petrology/egq070

Gao, J.-F., Lu, J.-J., Lai, M.-Y., Lin, Y.-P., and Pu, W., 2003, Analysis of trace elements in rock samples using HR-ICPMS: Journal of Nanjing University (Natural Sciences), v. 39, p. 844-850 (in Chinese with English abstract).

Ge, X.-Y., ms, 2003, Mesozoic magmatism in Hainan Island (SE China) and its tectonic significance: 
geochronology, geochemistry and Sr-Nd isotope evidences: Guangzhou,The Chinese Academy of Sciences, Ph. D. thesis, 87 p. (in Chinese with English abstract).

Gilder, S. A., Keller, G. R., Luo, M., and Goodell, P. C., 1991, Eastern Asia and the Western Pacific timing and spatial distribution of rifting in China: Tectonophysics, v. 197, n. 2-4, p. 225-243, http://dx.doi.org/ 10.1016/0040-1951(91)90043-R

Goldschmidt, V. M., 1958, Geochemistry: Londo, Oxford University Press, 730 p.

Goldsmith, J. R., 1950, Gallium and germanium substitutions in synthetic feldspars: The Journal of Geology, v. 58, n. 5, p. 518-536, http://dx.doi.org/10.1086/625760

Goodell, P. C., Gilder, S., and Fang, X., 1991, A preliminary description of the Gan-Hang failed rift, southeastern China: Tectonophysics, v. 197, n. 2-4, p. 245-255, http://dx.doi.org/10.1016/00401951(91)90044-S

Goodman, R. J., 1972, The distribution of $\mathrm{Ga}$ and $\mathrm{Rb}$ in coexisting groundmass and phenocryst phases of some basic volcanic rocks: Geochimica et Cosmochimica Acta, v. 36, n. 3, p. 303-317, http://dx.doi.org/ 10.1016/0016-7037(72)90025-7

Griffin, W. L., Pearson, N. J., Belousova, E. A., and Saeed, A., 2006, Comment: Hf-isotope heterogeneity in zircon 91500: Chemical Geology, v. 233, n. 3-4, p. 358-363, http://dx.doi.org/10.1016/j.chemgeo. 2006.03.007

Gualda, G. A. R., and Ghiorso, M. S., 2013. Low-pressure origin of high-silica rhyolites and granites. The Journal of Geology, v. 121, n. 5, p. 537-545, http://dx.doi.org/10.1086/671395

He, Z.-Y., and Xu, X.-S., 2012, Petrogenesis of the Late Yanshanian mantle-derived intrusions in southeastern China: Response to the geodynamics of paleo-Pacific plate subduction: Chemical Geology, v. 328, p. 208-221, http://dx.doi.org/10.1016/j.chemgeo.2011.09.014

Howell, D. G., 1995, Principles of Terrane Analysis: New York, Chapman \& Hall, Topics in the Earth Sciences, $245 \mathrm{p}$.

Huang, H.-Q., Li, X.-H., Li, W.-X., and Li, Z.-X., 2011, Formation of high $\mathrm{d}^{18} \mathrm{O}$ fayalite-bearing A-type granite by high-temperature melting of granulitic metasedimentary rocks, southern China: Geology, v. 39, n. 10, p. 903-906, http://dx.doi.org/10.1130/G32080.1

Humphreys, E., 2009, Relation of flat subduction to magmatism and deformation in the Western United States, in Kay, S. M, Ramos, V. A., and Dickinson, W. R., editors: Geological Society of America, Memoirs, v. 204, p. 85-98, http://dx.doi.org/10.1130/2009.1204(04)

Humphreys, E., Hessler, E., Dueker, K., Farmer, G. L., Erslev, E., and Atwater, T., 2003, How Laramide-age hydration of North American lithosphere by the Farallon slab controlled subsequent activity in the western United States: International Geology Review, v. 45, p. 575-595, doi:10.2747/0020-6814.45.7.575

Ishihara, S., Hashimoto, M., and Machida, M., 2000, Magnetite/Ilmenite-series Classification and Magnetic Susceptibility of the Mesozoic-Cenozoic Batholiths in Peru: Resource Geology, v. 50, p. 123-129, http://dx.doi.org/10.1111/j.1751-3928.2000.tb00062.x

Jackson, S. E., Pearson, N. J., Griffin, W. L., and Belousova, E. A., 2004, The application of laser ablation-inductively coupled plasma-mass spectrometry to in situ U-Pb zircon geochronology: Chemical Geology, v. 211, n. 1-2, p. 47-69, http://dx.doi.org/10.1016/j.chemgeo.2004.06.017

Jahn, B.-M., Zhou, X.-H., and Li, J.-L., 1990, Formation and tectonic evolution of Southeastern China and Taiwan: Isotopic and geochemical constraints: Tectonophysics, v. 183, n. 1-4, p. 145-160, http:// dx.doi.org/10.1016/0040-1951(90)90413-3

JGS (Jiangxi Geological Survey), 1980. Regional Geology of Guangfeng area: Jiangxi Province, Bureau of Geology and Mineral Resources of Jiangxi Province, 289 p. (in Chinese).

Jiang, Y.-H., Zhao, P., Zhou, Q., Liao, S.-Y., and Jin, G.-D., 2011, Petrogenesis and tectonic implications of Early Cretaceous S- and A-type granites in the northwest of the Gan-Hang rift, SE China: Lithos, v. 121, n. 1-4, p. 55-73, http://dx.doi.org/10.1016/j.lithos.2010.10.001

Kay, S. M., and Gordillo, C. E., 1994, Pocho volcanic rocks and the melting of depleted continental lithosphere above a shallowly dipping subduction zone in the central Andes: Contributions to Mineralogy and Petrology, v. 117, n. 1, p. 25-44, http://dx.doi.org/10.1007/bf00307727

Kay, S. M., and Mpodozis, C., 2001, Central Andean ore deposits linked to evolving shallow subduction systems and thickening crust: GSA Today, v. 11, p. 4-9, http://dx.doi.org/10.1130/10525173(2001)011<0004:CAODLT $>2.0 . \mathrm{CO} ; 2$

Kelemen, P. B., Hanghøj, K., and Greene, A. R., 2003, One view of the geochemistry of subduction-related magmatic arcs, with an emphasis on primitive andesite and lower crust, in Rudnick, R. L. editor, The Crust: Treatise on Geochemistry, v. 3, p. 593-659, http://dx.doi.org/10.1016/B0-08-043751-6/03035-8

Klein, C., and Philpotts, A. R., 2013, Earth Materials: Introduction to Mineralogy and Petrology: Cambridge, Cambridge University Press, 533 p.

Lapierre, H., Jahn, B.-M., Charvet, J., and Yu, Y.-W., 1997, Mesozoic felsic arc magmatism and continental olivine tholeiites in Zhejiang Province and their relationship with the tectonic activity in southeastern China: Tectonophysics, v. 274, n. 4, p. 321-338, http://dx.doi.org/10.1016/S0040-1951(97)00009-7

Le Maitre, R. W., 2002, Igneous rocks: a classification and glossary of terms: recommendations of the International Union of Geological Sciences, Subcommission on the Systematics of Igneous Rocks: Cambridge, Cambridge University Press, 236 p.

Li, J.-R., 2011, ms, Geochronology, geochemistry and petrogenesis of the Jintan granites from the Xiajiang uranium ore district, Jiangxi: Nanjing, China, Nanjing University, M. S. thesis, 49 p. (in Chinese with English abstract).

Li, P.-J., Yu, X.-Q., Li, H.-Y., Qiu, J.-T., and Zhou, X., 2013a, Jurassic-Cretaceous tectonic evolution of Southeast China: geochronological and geochemical constraints of Yanshanian granitoids: International Geology Review, v. 55, n. 10, p. 1202-1219, http://dx.doi.org/10.1080/00206814.2013.771952

Li, W.-Y., Ma, C.-Q., Liu, Y.-Y., and Robinson, P. T., 2012a, Discovery of the Indosinian aluminum A-type 
granite in Zhejiang Province and its geological significance: Science China Earth Sciences, v. 55, n. 1, p. 13-25, http://dx.doi.org/10.1007/s11430-011-4351-6

Li, X.-H., 2000, Cretaceous magmatism and lithospheric extension in Southeast China: Journal of Asian Earth Sciences, v. 18, n. 1, p. 293-305, http://dx.doi.org/10.1016/s1367-9120(99)00060-7

Li, X.-H., Li, Z.-X., Li, W.-X., and Wang, Y.-J., 2006, Initiation of the Indosinian orogeny in South China: Evidence for a permian magmatic arc on Hainan Island: The Journal of Geology, v. 114, p. 341-353, http://dx.doi.org/10.1086/501222

Li, X.-H., Li, W.-X., Li, Z.-X., and Liu, Y., 2008, 850-790 Ma bimodal volcanic and intrusive rocks in northern Zhejiang, South China: A major episode of continental rift magmatism during the breakup of Rodinia: Lithos, v. 102, n. 1-2, p. 341-357, http://dx.doi.org/10.1016/j.lithos.2007.04.007

Li, X.-H., Li, W.-X., Li, Z.-X., Lo, C.-H., Wang, J., Ye, M.-F., and Yang, Y.-H., 2009, Amalgamation between the Yangtze and Cathaysia Blocks in South China: Constraints from SHRIMP U-Pb zircon ages, geochemistry and Nd-Hf isotopes of the Shuangxiwu volcanic rocks: Precambrian Research, v. 174, n. 1-2, p. 117-128, http://dx.doi.org/10.1016/j.precamres.2009.07.004

Li, X.-H., Li, Z.-X., He, B., Li, W.-X., Li, Q.-L., Gao, Y.-Y., and Wang, X.-C., 2012b, The Early Permian active continental margin and crustal growth of the Cathaysia Block: In situ $\mathrm{U}-\mathrm{Pb}, \mathrm{Lu}-\mathrm{Hf}$ and $\mathrm{O}$ isotope analyses of detrital zircons: Chemical Geology, v. 328, p. 195-207, http://dx.doi.org/10.1016/ j.chemgeo.2011.10.027

Li, X.-H., Li, Z.-X., Li, W.-X., Wang, X.-C., and Gao, Y.-Y., 2013b. Revisiting the "C-type adakites" of the Lower Yangtze River Belt, central eastern China: In-situ zircon Hf-O isotope and geochemical constraints: Chemical Geology, v. 345, p. 1-15, http://dx.doi.org/10.1016/j.chemgeo.2013.02.024

Li, Z.-X., Li, X.-H., Zhou, H.-W., and Kinny, P. D., 2002, Grenvillian continental collision in south China: New SHRIMP U-Pb zircon results and implications for the configuration of Rodinia: Geology, v. 30, n. 2, p. 163-166, http://dx.doi.org/10.1130/0091-7613(2002)030<0163:gccisc $\rangle 2.0 . c o ; 2$

Li, Z.-X., and Li, X.-H., 2007, Formation of the 1300-km-wide intracontinental orogen and postorogenic magmatic province in Mesozoic South China: A flat-slab subduction model: Geology, v. 35, n. 2, p. 179-182, http://dx.doi.org/10.1130/g23193a.1

Li, Z.-X., Li, X.-H., Wartho, J.-A., Clark, C., Li, W.-H., Zhang, C.-L., and Bao, C.-M., 2010, Magmatic and metamorphic events during the early Paleozoic Wuyi-Yunkai orogeny, southeastern South China: New age constraints and pressure-temperature conditions: Geological Society of America Bulletin, v. 122, n. 5-6, B30021.1, http://dx.doi.org/10.1130/b30021.1

Li, Z.-X., Li, X.-H., Chung, S.-L., Lo, C.-H., Xu, X.-S., and Li, W.-X., 2012c, Magmatic switch-on and switch-off along the South China continental margin since the Permian: Transition from an Andean-type to a Western Pacific-type plate boundary: Tectonophysics, v. 532-535, p. 271-290, http://dx.doi.org/10.1016/ j.tecto.2012.02.011

Lipman, P. W., Doe, B. R., Hedge, C. E., and Steven, T. A., 1978, Petrologic evolution of the San Juan volcanic field, southwestern Colorado: $\mathrm{Pb}$ and $\mathrm{Sr}$ isotope evidence: Geological Society of America Bulletin, v. 89, n. 1, p. 59-82, http://dx.doi.org/10.1130/0016-7606(1978) 89<59:peotsj/2.0.co;2

Lipman, P. W., 1987, Rare-earth-element compositions of Cenozoic volcanic rocks in the southern Rocky Mountains and adjacent areas: Washington, D.C., USGS Bulletion 1668.

2004, Chemical Analyses Of Tertiary Volcanic Rocks, Central San Juan Caldera Complex, Southwestern Colorado: USGS Open-File Report 2004-1194.

2006, Geologic Map of the Central San Juan Caldera Cluster, Southwestern Colorado: USGS Geologic Investigations Series I-2799.

Liu, L., Qiu, J.-S., and Li, Z., 2011, Zircon U-Pb age and Hf isotopic compositions of quartz monzonite and enclosed mafic enclaves in Muchen pluton, Zhejiang Province: tracing magma mixing in their petrogenesis: Geological Review, v. 57, p. 327-336 (in Chinese with English abstract).

2013, Origin of mafic microgranular enclaves (MMEs) and their host quartz monzonites from the Muchen pluton in Zhejiang Province, Southeast China: Implications for magma mixing and crustmantle interaction: Lithos, v. 160-161, p. 145-163, http:/ / dx.doi.org/10.1016/j.lithos.2012.12.005

Liu, L., Xu, X.-S., and Zou, H.-B., 2012, Episodic eruptions of the Late Mesozoic volcanic sequences in southeastern Zhejiang, SE China: Petrogenesis and implications for the geodynamics of paleo-Pacific subduction: Lithos, v. 154, p. 166-180, http://dx.doi.org/10.1016/j.lithos.2012.07.002

Liu, Y.-S., Zong, K.-Q., Kelemen, P. B., and Gao, S., 2008, Geochemistry and magmatic history of eclogites and ultramafic rocks from the Chinese continental scientific drill hole: Subduction and ultrahighpressure metamorphism of lower crustal cumulates: Chemical Geology, v. 247, n. 1-2, p. 133-153, http:/ /dx.doi.org/10.1016/j.chemgeo.2007.10.016

Loiselle, M. C., and Wones, D. R., 1979, Characteristics and origin of anorogenic granites: Geological Society of America Abstracts with Programs, v. 11, p. 468.

Lu, C.-Z., 2007, Geochemical characteristics and tectonic implications of Muchen quartz monzonite pluton in Zhejiang Province: Geochimica, v. 36, p. 457-466 (in Chinese with English abstract).

Lu, C.-Z., Wang, Q.-H., Dong, C.-W., and Dong, X.-F., 2006, Geochemical characteristics of the Honggong aluminous A-type granite pluton in Zhejiang Province and its tectonic setting: Geological Journal of China Universities, v. 12, p. 500-506 (in Chinese with English abstract).

Lugwig, K. R., 2008, Isoplot 3.71: Berkeley, California, Berkeley Geochronology Center, 77 p.

2009, Squid 2.5: Berkeley, California, Berkeley Geochronology Center, 110 p.

Mamani, M., Wörner, G., and Sempere, T., 2010, Geochemical variations in igneous rocks of the Central Andean orocline $\left(13^{\circ} \mathrm{S}\right.$ to $\left.18^{\circ} \mathrm{S}\right)$ : Tracing crustal thickening and magma generation through time and space: Geological Society of America Bulletin, v. 122, n. 1-2, p. 162-182, http://dx.doi.org/10.1130/ b26538.1

Mao, J.-R., Takahashi, Y., Kee, W. S., Li, Z.-L., Ye, H.-M., Zhao, X.-L., Liu, K., and Zhou, J., 2011, 
Characteristics and geodynamic evolution of Indosinian magmatism in South China: A case study of the Guikeng pluton: Lithos, v. 127, n. 3-4, p. 535-551, http://dx.doi.org/10.1016/j.lithos.2011.09.011

Meng, L.-F., Li, Z.-X., Chen, H.-L., Li, X.-H., and Wang, X.,-C., 2012, Geochronological and geochemical results from Mesozoic basalts in southern South China Block support the flat-slab subduction model: Lithos, v. 132-133, p. 127-140, http://dx.doi.org/10.1016/j.lithos.2011.11.022

Miller, C. F., and Mittlefehldt, D. W., 1982, Depletion of light rare-earth elements in felsic magmas: Geology, v. 10, n. 3, p. 129-133, http://dx.doi.org/10.1130/0091-7613(1982)10〈129:dolrei $\rangle 2.0 . c 0 ; 2$

Miller, C. F., McDowell, S. M., and Mapes, R. W., 2003, Hot and cold granites? Implications of zircon saturation temperatures and preservation of inheritance: Geology, v. 31, n. 6, p. 529-532, http:// dx.doi.org/10.1130/0091-7613(2003)031<0529:hacgio $\rangle 2.0 . c 0 ; 2$

Moll-Stalcup, E., and Arth, J. G., 1989, The nature of the crust in the Yukon-Koyukuk Province as inferred from the chemical and isotopic composition of five Late Cretaceous to Early Tertiary volcanic fields in western Alaska: Journal of Geophysical Research-Solid Earth, v. 94, n. B11, p. 15989-16020, http:// dx.doi.org/10.1029/JB094iB11p15989

Moore, G., and Carmichael, I. S. E., 1998, The hydrous phase equilibria (to 3 kbar) of an andesite and basaltic andesite from western Mexico: constraints on water content and conditions of phenocryst growth: Contributions to Mineralogy and Petrology, v. 130, n. 3-4, p. 304-319, http://dx.doi.org/ $10.1007 / \mathrm{s} 004100050367$

Naney, M. T., 1983, Phase equilibria of rock-forming ferromagnesian silicates in granitic systems: American Journal of Science, v. 283, n. 10, p. 993-1033, http://dx.doi.org/10.2475/ajs.283.10.993

Nasdala, L., Hofmeister, W., Norberg, N., Martinson, J. M., Corfu, F., Dörr, W., Kamo, S. L., Kennedy, A. K., Kronz, A., Reiners, P. W., Frei, D., Kosler, J., Wan, Y., Götze, J., Häger, T., Kröner, A., and Valley, J. W., 2008, Zircon M257-a homogeneous natural reference material for the ion microprobe U-Pb analysis of zircon: Geostandards and Geoanalytical Research, v. 32, p. 247-265, http://dx.doi.org/10.1111/j.1751908X.2008.00914.x

O'Hara, M. J., 1961, Zoned Ultrabasic and basic gneiss masses in the early Lewisian metamorphic complex at Scourie, Sutherland:Journal of Petrology, v. 2, n. 2, p. 248-276, http://dx.doi.org/10.1093/petrology/ 2.2.248

Orozco, L. A., Favetto, A., Pomposiello, C., Rossello, E., and Booker, J., 2013, Crustal deformation of the Andean foreland at $31^{\circ} 30^{\prime} \mathrm{S}$ (Argentina) constrained by magnetotelluric survey: Tectonophysics, v. 582 , p. 126-139, http://dx.doi.org/10.1016/j.tecto.2012.09.030

Palme, H., and O'Neill, H. St. C., 2003, Cosmochemical estimates of mantle composition, in Carlson, R. W., editor, The Mantle and the Core: Treatise on geochemistry, v. 2, p. 1-38, http://dx.doi.org/10.1016/ B0-08-043751-6/02177-0

Patiño Douce, A. E., and Beard, J. S., 1995, Dehydration-melting of biotite gneiss and quartz amphibolite from 3 to 15 kbar: Journal of Petrology, v. 36, n. 3, p. 707-738, http://dx.doi.org/10.1093/petrology/ 36.3.707

Pearce, J. A., Harris, N. B. W., and Tindle, A. G., 1984, Trace element discrimination diagrams for the tectonic interpretation of granitic rocks: Journal of Petrology, v. 25, n. 4, p. 956-983, http://dx.doi.org/ 10.1093 /petrology/25.4.956

Qi, C.-S., Deng, X.-G., Li, X.-H., Li, W.-X., Yang, Y.-H., and Xie, L.-W., 2007, Origin of the DarongshanShiwandashan S-type granitoid belt from southeastern Guangxi: geochemical and Sr-Nd-Hf isotopic constraints: Acta Petrologica Sinica, v. 23, p. 403-412 (in Chinese with English abstract).

Qian, Q., and Hermann, J., 2013, Partial melting of lower crust at 10-15 kbar: constraints on adakite and TTG formation: Contributions to Mineralogy and Petrology, v. 165, n. 6, p. 1195-1224, http:// dx.doi.org/10.1007/s00410-013-0854-9

Qin, S.-C., ms, 2007, Geochronology and geochemistry of Cretaceous mafic volcanic rocks from Zhejiang and Fujian Provinces, SE China: petrogenesis and geodynamic implication for lithospheric extension: Guangzhou, China, The Chinese Academy of Sciences, Ph. D. thesis, 113 p. (in Chinese with English abstract).

Qiu, J.-T., Yu, X.-Q., Santosh, M., Zhang, D.-H., Chen, S.-Q., and Li, P.-J., 2013, Geochronology and magmatic oxygen fugacity of the Tongcun molybdenum deposit, northwest Zhejiang, SE China: Mineralium Deposita, v. 48, n. 5, p. 545-556, http://dx.doi.org/10.1007/s00126-013-0456-5

Ramos, V. A., 2009, Anatomy and global context of the Andes: Main geologic features and the Andean orogenic cycle, in Kay S. M. and others, editors, Backbone of the Americas: Shallow Subduction, Plateau Uplift, and Ridge and Terrane Collision: Geological Society of America Memoirs, v. 204, p. 31-65, http://dx.doi.org/10.1130/2009.1204(02)

Ramos, V. A., and Folguera, A., 2009, Andean flat-slab subduction through time, in Murphy, J. B., Keppie, J. D., and Hynes, A. J., editors, Ancient Orogens and Modern Analogues: Geological Society, London, Special Publications, v. 327, p. 31-54, http://dx.doi.org/10.1144/SP327.3

Rankama, K., and Sahama, T. G., 1950, Geochemistry: Chicago, The University of Chicago Press, 912 p.

Richards, J. P., 2011, High Sr/Y arc magmas and porphyry Cu \pm Mo \pm Au deposits: Just add water: Economic Geology, v. 106, n. 7, p. 1075-1081, http://dx.doi.org/10.2113/econgeo.106.7.1075

Ringwood, A. E., 1955, The principles governing trace-element behaviour during magmatic crystallization: Part II. The role of complex formation: Geochimica et Cosmochimica Acta, v. 7, n. 56, p. 242-254, http:/ /dx.doi.org/10.1016/0016-7037(55)90036-3

Rudnick, R. L., and Gao, S., 2003, Composition of the continental crust, in Rudnick, R. L., editors, The Crust: Treatise on Geochemistry, v. 3, p. 1-64, http://dx.doi.org/10.1016/B0-08-043751-6/03016-4

Russell, W. A., Papanastassiou, D. A., and Tombrello, T. A., 1978, Ca isotope fractionation on the Earth and other solar system materials: Geochimica et Cosmochimica Acta, v. 42, n. 8, p. 1075-1090, http:// dx.doi.org/10.1016/0016-7037(78)90105-9 
Shervais, J. W., 1982, Ti-V plots and the petrogenesis of modern and ophiolitic lavas: Earth and Planetary Science Letters, v. 59, n. 1, p. 101-118, http://dx.doi.org/10.1016/0012-821x(82)90120-0

Söderlund, U., Patchett, P. J., Vervoort, J. D., and Isachsen, C. E., 2004, The ${ }^{176}$ Lu decay constant determined by $\mathrm{Lu}-\mathrm{Hf}$ and $\mathrm{U}-\mathrm{Pb}$ isotope systematics of Precambrian mafic intrusions: Earth and Planetary Science Letters, v. 219, n. 3-4, p. 311-324, http://dx.doi.org/10.1016/S0012-821X(04)00012-3

Sun, Y., Ma, C.-Q., Liu, Y.-Y., and She, Z.-B., 2011, Geochronological and geochemical constraints on the petrogenesis of late Triassic aluminous A-type granites in southeast China: Journal of Asian Earth Sciences, v. 42, n. 6, p. 1117-1131, http://dx.doi.org/10.1016/j.jseaes.2011.06.007

Thirlwall, M. F., and Anczkiewicz, R., 2004, Multidynamic isotope ratio analysis using MC-ICP-MS and the causes of secular drift in $\mathrm{Hf}, \mathrm{Nd}$ and $\mathrm{Pb}$ isotope ratios: International Journal of Mass Spectrometry, v. 235 , n. 1, p. 59-81, http://dx.doi.org/10.1016/j.ijms.2004.04.002

Tuttle, O. F., and Bowen, N. L., 1958, Origin of granite in the light of experimental studies in the system $\mathrm{NaAlSi}_{3} \mathrm{O}_{8}-\mathrm{KAiSi}_{3} \mathrm{O}_{8}-\mathrm{SiO}_{2}-\mathrm{H}_{2} \mathrm{O}$ : Geological Society of America, Memoirs, v. 74, p. 1-146, http:// dx.doi.org/10.1130/MEM74-p1

Vielzeuf, D., and Montel, J.-M., 1994, Partial melting of metagreywackes. Part I. Fluid-absent experiments and phase relationships: Contributions to Mineralogy and Petrology, v. 117, n. 4, p. 375-393, http:// dx.doi.org/10.1007/BF00307272

Villaseca, C., Orejana, D., and Paterson, B. A., 2007, Zr-LREE rich minerals in residual peraluminous granulites, another factor in the origin of low Zr-LREE granitic melts?: Lithos, v. 96, n. 3-4, p. 375-386, http://dx.doi.org/10.1016/j.lithos.2006.11.002

Wang, K.-X., Sun, T., Chen, P.-R., Ling, H.-F., and Xiang, T.-F., 2013, The geochronological and geochemical constraints on the petrogenesis of the Early Mesozoic A-type granite and diabase in northwestern Fujian province: Lithos, v. 179, p. 364-381, http://dx.doi.org/10.1016/j.lithos.2013.07.016

Wang, L., Hu, M.-A., Yang, Z., Qu, W.-J., Xia, J.-L., and Chen, K.-X., 2011, U-Pb and Re-Os geochronology and geodynamic setting of the Dabaoshan polymetallic deposit, northern Guangdong Province, South China: Ore Geology Reviews, v. 43, n. 1, p. 40-49, http://dx.doi.org/10.1016/j.oregeorev.2011.06.008

Wang, Q., Li, J.-W., Jian, P., Zhao, Z.-H., Xiong, X.-L., Bao, Z.-W., Xu, J.-F., Li, C.-F., and Ma, J.-L., 2005b, Alkaline syenites in eastern Cathaysia (South China): link to Permian-Triassic transtension: Earth and Planetary Science Letters, v. 230, n. 3-4, p. 339-354, http://dx.doi.org/10.1016/j.epsl.2004.11.023

Wang, X.-L., Jiang, S.-Y., and Dai, B.-Z., 2010, Melting of enriched Archean subcontinental lithospheric mantle: Evidence from the $c a$. 1760 Ma volcanic rocks of the Xiong'er Group, southern margin of the North China Craton: Precambrian Research, v. 182, n. 3, p. 204-216, http://dx.doi.org/10.1016/ j.precamres.2010.08.007

Wang,Y.-J., Zhang, Y.-H., Fan, W.-M., and Peng, T.-P., 2005a, Structural signatures and ${ }^{40} \mathrm{Ar} /{ }^{39} \mathrm{Ar}$ geochronology of the Indosinian Xuefengshan tectonic belt, South China Block: Journal of Structural Geology, v. 27, n. 6, p. 985-998, http://dx.doi.org/10.1016/j.jsg.2005.04.004

Wang, Y.-J., Fan, W.-M., Sun, M., Liang, X.-Q., Zhang, Y.-H., and Peng, T.-P., 2007, Geochronological, geochemical and geothermal constraints on petrogenesis of the Indosinian peraluminous granites in the South China Block: A case study in the Hunan Province: Lithos, v. 96, n. 3-4, p. 475-502, http://dx.doi.org/10.1016/j.lithos.2006.11.010

Watson, E. B., 1979, Zircon saturation in felsic liquids: Experimental results and applications to trace element geochemistry: Contributions to Mineralogy and Petrology, v. 70, n. 4, p. 407-419, http:// dx.doi.org/10.1007/BF00371047

Wedepohl, K. H., 1973, Handbook of Geochemistry: Berlin, Springer-Verlag, 667 p

Whalen, J. B., Currie, K. L., and Chappell, B. W., 1987, A-type granites: geochemical characteristics, discrimination and petrogenesis: Contributions to Mineralogy and Petrology, v. 95, n. 4, p. 407-419, http://dx.doi.org/10.1007/BF00402202

Whitney, J. A., 1988, The origin of granite: The role and source of water in the evolution of granitic magmas: Geological Society of America Bulletin, v. 100, n. 12, p. 1886-1897, http://dx.doi.org/10.1130/00167606(1988) 100<1886:toogtr $>2.3 . c 0 ; 2$

Wones, D. R., 1989, Significance of the assemblage titanite+magnetite+quartz in granitic rocks: American Mineralogist, v. 74, p. 744-749.

Wong, I., Sun, M., Xing, G.-F., Li, X.-H., Zhao, G.-C., Wong, K., Yuan, C., Xia, X.-P., Li, L.-M., and Wu, F.-Y., 2009, Geochemical and zircon U-Pb and Hf isotopic study of the Baijuhuajian metaluminous A-type granite: Extension at 125-100 Ma and its tectonic significance for South China: Lithos, v. 112, n. 3-4, p. 289-305, http://dx.doi.org/10.1016/j.lithos.2009.03.009

Wong, J., Sun, M., Xing, G.-F., Li, X.-H., Zhao, G.-C., Wong, K., and Wu, F.-Y., 2011, Zircon U-Pb and Hf isotopic study of Mesozoic felsic rocks from eastern Zhejiang, South China: Geochemical contrast between the Yangtze and Cathaysia blocks: Gondwana Research, v. 19, n. 1, p. 244-259, http:// dx.doi.org/10.1016/j.gr.2010.06.004

Woodhead, J. D., and Hergt, J. M., 2005, A preliminary appraisal of seven natural zircon reference materials for in situ Hf isotope determination: Geostandards and Geoanalytical Research, v. 29, n. 2, p. 183-195, http://dx.doi.org/10.1111/j.1751-908X.2005.tb00891.x

Xia, Y., Xu, X.-S., and Zhu, K.-Y., 2012, Paleoproterozoic S- and A-type granites in southwestern Zhejiang: Magmatism, metamorphism and implications for the crustal evolution of the Cathaysia basement: Precambrian Research, v. 216-219, p. 177-207, http://dx.doi.org/10.1016/j.precamres.2012.07.001

Xiao, W.-J., and He, H.-Q., 2005, Early Mesozoic thrust tectonics of the northwest Zhejiang region (Southeast China): Geological Society of America Bulletin, v. 117, n. 7-8, p. 945-961, http://dx.doi.org/10.1130/ b25417.1

Xu, X.-S., O'Reilly, S. Y., Griffin, W. L., Wang, X.-L., Pearson, N. J., and He, Z.-Y., 2007. The crust of Cathaysia: Age, assembly and reworking of two terranes: Precambrian Research, v. 158, n. 1-2, p. 51-78, http://dx.doi.org/10.1016/j.precamres.2007.04.010 
Yang, S.-Y., Jiang, S.-Y., Zhao, K.-D., and Jiang, Y.-H., 2013, Petrogenesis and tectonic significance of Early Cretaceous high-Zr rhyolite in the Dazhou uranium district, Gan-Hang Belt, Southeast China: Journal of Asian Earth Sciences, v. 74, p. 303-315, http://dx.doi.org/10.1016/j.jseaes.2012.12.024

Ye, M.-F., Li, X.-H., Li, W.-X., Liu, Y., and Li, Z.-X., 2007, SHRIMP zircon U-Pb geochronological and whole-rock geochemical evidence for an early Neoproterozoic Sibaoan magmatic arc along the southeastern margin of the Yangtze Block: Gondwana Research, v. 12, n. 1-2, p. 144-156, http:// dx.doi.org/10.1016/j.gr.2006.09.001

Yoder, H. S., Stewart, D. B., and Smith, J. R., 1957, Ternary feldspars: Carnegie Institution of Washington Year Book, v. 56, p. 206-214.

Yu, J.-H., Wang, L.-J., O'Reilly, S. Y., Griffin, W. L., Zhang, M., Li, C.-Z., and Shu, L.-S., 2009, A Paleoproterozoic orogeny recorded in a long-lived cratonic remnant (Wuyishan terrane), eastern Cathaysia Block, China: Precambrian Research, v. 174, n. 3-4, p. 347-363, http://dx.doi.org/10.1016/ j.precamres.2009.08.009

Yu, J.-H., O'Reilly, S. Y., Zhou, M.-F., Griffin, W. L., and Wang, L., 2012, U-Pb geochronology and Hf-Nd isotopic geochemistry of the Badu Complex, Southeastern China: Implications for the Precambrian crustal evolution and paleogeography of the Cathaysia Block: Precambrian Research, v. 222-223, p. 424-449, http://dx.doi.org/10.1016/j.precamres.2011.07.014

Zeng, Q.-D., Wang, Y.-B., Zhang, S., Liu, J.-M., Qin, K.-Z., Yang, J.-H., Sun, W.-D., and Qu, W.-I., 2013, U-Pb and $\mathrm{Re}-\mathrm{Os}$ geochronology of the Tongcun molybdenum deposit and Zhilingtou gold-silver deposit in Zhejiang Province, southeast China, and its geological implications: Resource Geology, v. 63, p. 99-109, http://dx.doi.org/10.1111/j.1751-3928.2012.00213.x

ZGS (Zhejiang Geological Survey), 1965, Regional Geology of Jiande area, Zhejiang Province: Meicheng, Bureau of Geology and Mineral Resources of Zhejiang Province, 162 p. (in Chinese).

1966, Regional Geology of Jinhua area, Zhejiang Province: Meicheng, Bureau of Geology and Mineral Resources of Zhejiang Province, 117 p. (in Chinese).

Zhang, Z.-J., Badal, J., Li, Y.-K., Chen, Y., Yang, L.-Q., and Teng, J.-W., 2005, Crust-upper mantle seismic velocity structure across Southeastern China: Tectonophysics, v. 395, n. 1-2, p. 137-157, http:// dx.doi.org/10.1016/j.tecto.2004.08.008

Zhao, K.-D., Jiang, S.-Y., Chen, W.-F., Chen, P.-R., and Ling, H.-F., 2013, Zircon U-Pb chronology and elemental and Sr-Nd-Hf isotope geochemistry of two Triassic A-type granites in South China: Implication for petrogenesis and Indosinian transtensional tectonism: Lithos, v. 160-161, p. 292-306, http://dx.doi.org/10.1016/j.lithos.2012.11.001

Zhou, X.-M., and Li, W.-X., 2000, Origin of Late Mesozoic igneous rocks in Southeastern China: implications for lithosphere subduction and underplating of mafic magmas: Tectonophysics, v. 326, p. 269-287, n. 3-4, http:/ /dx.doi.org/10.1016/s0040-1951(00)00120-7

Zhou, X.-M., Sun, T., Shen, W.-Z., Shu, L.-S., and Niu, Y.-L., 2006, Petrogenesis of Mesozoic granitoids and volcanic rocks in South China: A response to tectonic evolution: Episodes, v. 29, p. 26-33.

Zhu, K.-Y., Li, Z.-X., Xu, X.-S., and Wilde, S. A., 2013, Late Triassic melting of a thickened crust in southeastern China: Evidence for flat-slab subduction of the Paleo-Pacific plate: Journal of Asian Earth Sciences, v. 74, p. 265-279, http://dx.doi.org/10.1016/j.jseaes.2013.01.010 